\title{
Dynamics and distribution of natural and human-caused hypoxia
}

\author{
N. N. Rabalais ${ }^{1}$, R. J. Díaz ${ }^{2}$, L. A. Levin ${ }^{3}$, R. E. Turner ${ }^{4}$, D. Gilbert ${ }^{5}$, and J. Zhang ${ }^{6}$ \\ ${ }^{1}$ Louisiana Universities Marine Consortium, Chauvin, Louisiana 70344, USA \\ ${ }^{2}$ Virginia Institute of Marine Science, College of William and Mary, Gloucester Point, Virginia 23062, USA \\ ${ }^{3}$ Integrative Oceanography Division, Scripps Institution of Oceanography, 9500 Gilman Drive, La Jolla, \\ California 92093-0218, USA \\ ${ }^{4}$ Department of Oceanography and Coastal Sciences, Louisiana State University, Baton Rouge, Louisiana 70803, USA \\ ${ }^{5}$ Institut Maurice-Lamontagne, Pêches et Océans Canada, 850 route de la mer, Mont-Joli, Québec, G5H 3Z4, Canada \\ ${ }^{6}$ State Key Laboratory of Estuarine and Coastal Research, East China Normal University, 3663 Zhongshan Road North, \\ Shanghai 200062, China
}

Received: 31 August 2009 - Published in Biogeosciences Discuss.: 1 October 2009

Revised: 11 January 2010 - Accepted: 24 January 2010 - Published: 12 February 2010

\begin{abstract}
Water masses can become undersaturated with oxygen when natural processes alone or in combination with anthropogenic processes produce enough organic carbon that is aerobically decomposed faster than the rate of oxygen reaeration. The dominant natural processes usually involved are photosynthetic carbon production and microbial respiration. The re-supply rate is indirectly related to its isolation from the surface layer. Hypoxic water masses $\left(<2 \mathrm{mg} \mathrm{L}^{-1}\right.$, or approximately $30 \%$ saturation) can form, therefore, under "natural" conditions, and are more likely to occur in marine systems when the water residence time is extended, water exchange and ventilation are minimal, stratification occurs, and where carbon production and export to the bottom layer are relatively high. Hypoxia has occurred through geological time and naturally occurs in oxygen minimum zones, deep basins, eastern boundary upwelling systems, and fjords.

Hypoxia development and continuation in many areas of the world's coastal ocean is accelerated by human activities, especially where nutrient loading increased in the Anthropocene. This higher loading set in motion a cascading set of events related to eutrophication. The formation of hypoxic areas has been exacerbated by any combination of interactions that increase primary production and accumulation of organic carbon leading to increased respiratory demand for oxygen below a seasonal or permanent pycnocline. Nutrient loading is likely to increase further as population growth and resource intensification rises, especially with increased
\end{abstract}

Correspondence to: N. N. Rabalais

(nrabalais@lumcon.edu) dependency on crops using fertilizers, burning of fossil fuels, urbanization, and waste water generation. It is likely that the occurrence and persistence of hypoxia will be even more widespread and have more impacts than presently observed.

Global climate change will further complicate the causative factors in both natural and human-caused hypoxia. The likelihood of strengthened stratification alone, from increased surface water temperature as the global climate warms, is sufficient to worsen hypoxia where it currently exists and facilitate its formation in additional waters. Increased precipitation that increases freshwater discharge and flux of nutrients will result in increased primary production in the receiving waters up to a point. The interplay of increased nutrients and stratification where they occur will aggravate and accelerate hypoxia. Changes in wind fields may expand oxygen minimum zones onto more continental shelf areas. On the other hand, not all regions will experience increased precipitation, some oceanic water temperatures may decrease as currents shift, and frequency and severity of tropical storms may increase and temporarily disrupt hypoxia more often.

The consequences of global warming and climate change are effectively uncontrollable at least in the near term. On the other hand, the consequences of eutrophication-induced hypoxia can be reversed if long-term, broad-scale, and persistent efforts to reduce substantial nutrient loads are developed and implemented. In the face of globally expanding hypoxia, there is a need for water and resource managers to act now to reduce nutrient loads to maintain, at least, the current status.

Published by Copernicus Publications on behalf of the European Geosciences Union. 


\section{Introduction}

Over the past five to ten years, changes in the ocean's dissolved oxygen content have become a focal point of oceanic research. The oxygen content in the open ocean appears to have decreased in most (but not all) areas (Gilbert et al., 2009). At the same time, low oxygen areas, also known as "dead zones", have spread in the coastal oceans during the last five decades. These changes in oxygen are an increasingly important topic due to large impacts on the ecosystems, living resources, and biogeochemical cycles. Hypoxic (low dissolved oxygen) and anoxic (no oxygen) aquatic environments have occurred through geologic time. In fact, the biological and physical processes that formed large deposits of oil in geologic formations are the same as those occurring in oil rich areas where hypoxia and anoxia exist presently, such as the Santa Barbara Basin, California, USA, a silled basin interacting with an oxygen minimum zone (Berelson, 1991), and the continental shelf of the northern Gulf of Mexico adjacent to the outflow of the Mississippi River (Rabalais et al., 2007b). Low oxygen waters in the world oceans are normal, or naturally formed, in areas such as oxygen minimum zones (OMZs), deep basins, upwelling areas of eastern boundary currents, and fjords (Helly and Levin, 2004). But in the 19th, 20th and 21st centuries, the activities of humans have resulted in many more areas of hypoxia than occurred historically and aggravated conditions in areas that were already low in oxygen (Fig. 1) (Díaz and Rosenberg, 1995, 2008; Vaquer-Sunyer and Duarte, 2008; Gooday et al., 2009b).

In contrast to what occurs in the OMZs and upwelling zones, much of the hypoxia and anoxia in shallow coastal marine areas has developed within the last $50 \mathrm{yr}$ and is closely associated with anthropogenic activities. Díaz and Rosenberg (1995) noted that no other environmental variable of such ecological importance to estuarine and coastal marine ecosystems has changed so drastically, in such a short period of time. They noted consistent trends of increasing severity in duration, intensity, or extent in areas where hypoxia has a long history, which were coincidental with an increase in human activities. In 1995 there were 195 literaturedocumented areas of human-caused coastal hypoxia. In their most recent compilation, Díaz and Rosenberg (2008) documented just over 400 such areas in the world's coastal ocean covering more than $245000 \mathrm{~km}^{2}$ of sea bottom (Fig. 1). The worldwide distribution of coastal hypoxia is related to major population centers or is closely associated with developed watersheds that export large quantities of nutrients, specifically nitrogen and phosphorus. Up to 1970 , there were scattered reports of hypoxia in North America and northern Europe. By the 1990s, coastal hypoxia was prevalent in North America, northern Europe, and Japan. By the 2000s, there were increased reports of hypoxia in South America, southern Europe, and Australia (Fig. 1). Considering the close association of human population and hypoxia, it is unlikely that Asia and the Indo-Pacific have no hypoxia.

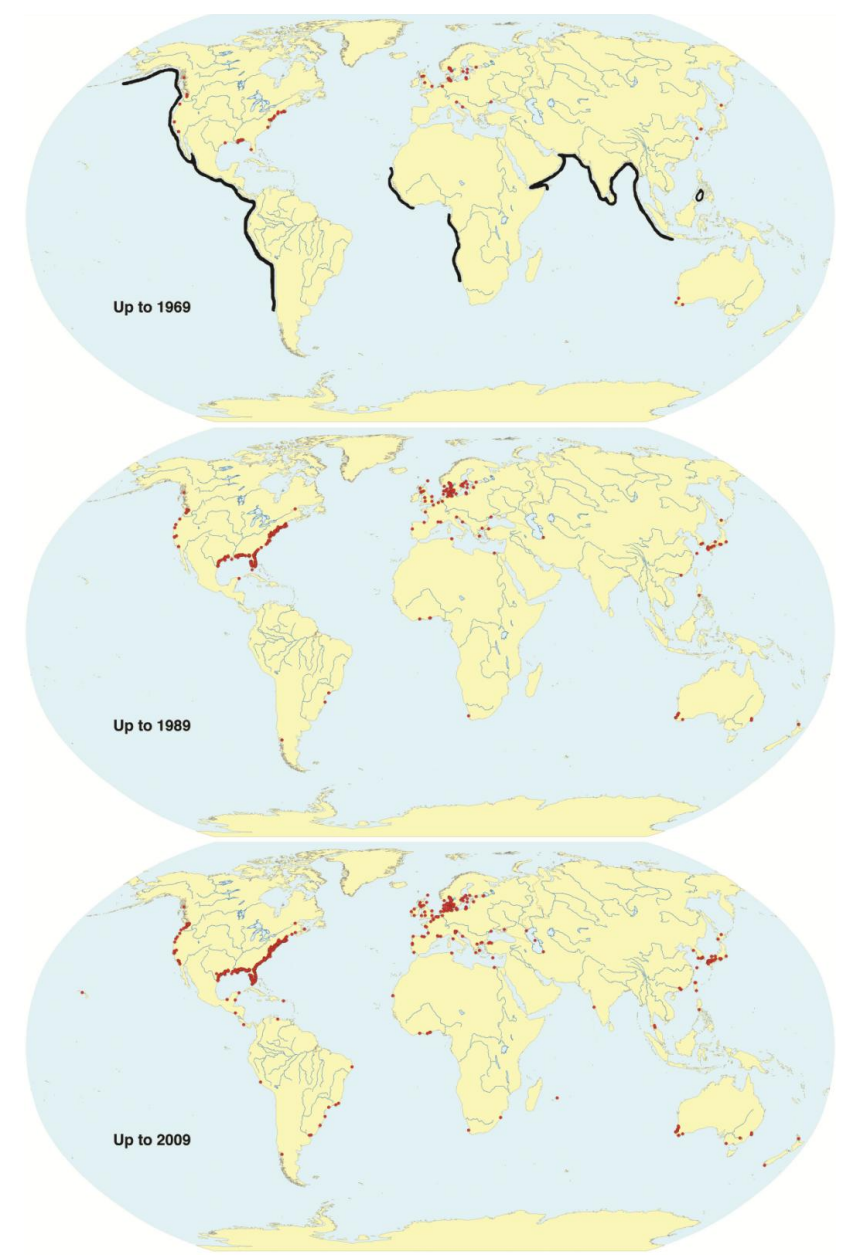

Fig. 1. Global pattern in the development of coastal hypoxia. Each red dot represents a documented case related to human activities. Number of hypoxic sites is cumulative through time. Black lines represent continental shelf areas threatened with hypoxia from expansion of $\mathrm{OMZ}$ and upwelling. Modified from Díaz and Rosenberg (2008) and Levin et al. (2009a).

Many systems that are currently hypoxic were not so when first studied. For systems with historical data from the first half of the 20th century, declines in oxygen concentrations started in the 1950s and 1960s for the northern Adriatic Sea (Justić et al., 1987), between the 1940s and 1960s for the northwest continental shelf of the Black Sea (see case studies), and in the 1970s for the Kattegat (Baden et al., 1990a). Declining dissolved oxygen levels were noted in the Baltic Sea as early as the 1930s (Fonselius, 1969), but it was in the 1950s that hypoxia became widespread (Karlson et al., 2002). Other systems have experienced hypoxia since the beginning of oxygen data collection, for example, in the 1900s for Kamak Bay, Korea (Lim et al., 2006), 1910s for Oslofjord, Norway (Mirza and Gray, 1981), 1920s for Thames Estuary, England (Andrews and Rickard, 1980), 1930s for Chesapeake Bay (Newcombe and Horne, 1938), 
and 1970s for the northern Gulf of Mexico (see case studies).

Hypoxia now occurs in many areas where it did not occur before, including estuarine and coastal areas. For example in the Kattegat, between Sweden and Denmark, classic descriptions of well-developed, advanced successional stage benthic communities were made by Petersen (1911). In the mid 1980s Petersen's stations were revisited, and it was determined that the benthic communities at most of the stations have undergone substantial changes over the $70 \mathrm{yr}$ period (Pearson et al., 1985). The general decrease of large species and increase of small-sized species was consistent with the hypothesis that intermittent low oxygen conditions affected many of the shallower areas of the Kattegat and kept the system in an early successional stage (Pearson et al., 1985). Moreover, in the deeper northeastern area where there is no evidence of low oxygen, both total biomass and mean individual size of the dominant species were greater than before, possibly suggesting that in these areas only enrichment had taken place (Pearson et al., 1985). By the mid 1980s severe seasonal hypoxia had developed in the southeastern Kattegat and negatively affected both the benthos and Norway lobster (Nephrops norvegicus) fisheries (Rosenberg and Loo, 1988; Baden et al., 1990a, b).

The negative effects of hypoxia include loss of suitable and required habitat for many bottom-dwelling fishes and benthic fauna, habitat compression for pelagic fishes, direct mortality, increased predation, decreased food resources, altered trophic energy transfer, altered bioenergetics (physiological, development, growth, and reproductive abnormalities) and altered migration. These result in reduced fisheries, including valuable finfishes and crustaceans (Jørgensen, 1980; Nissling and Vallin, 1996; Rabalais and Turner, 2001; Cheng et al., 2002; Eby and Crowder, 2002; Kodama et al., 2002; Wu, 2002; Wu et al., 2003; Baird et al., 2004; Breitburg et al., 2009). Increasing nutrient loads that also change the nutrient ratios can affect the composition of the phytoplankton community and can shift trophic interactions. Hypoxia also alters or interrupts ecosystem functions and services such as nutrient cycling and bioturbation (Turner et al., 1998; Gutiérrez et al., 2000; Dortch et al., 2001; Childs et al., 2002; Turner, 2001; Rabalais, 2004; Nizzoli et al., 2007; Weissberger et al., 2009; Middelburg and Levin, 2009).

This paper is one of several in this special issue culminating from the activities of the SCOR (Scientific Committee on Ocean Research) Working Group (WG) 128 on "Natural and Human-Induced Hypoxia and Consequences for Coastal Areas". The focus of the Working Group was coastal waters, but other marine systems with hypoxia, such as anoxic basins, oxygen minimum zones, or areas of upwelling are of interest for understanding comparative processes and dynamics. Hypoxic waters from OMZs and upwelling systems may also impinge on coastal areas with similar affects as humaninduced hypoxia (Levin et al., 2009a).

\section{Definitions and terminology}

Aquatic ecologists have borrowed the term hypoxia (low oxygen) from the medical community but the meaning and processes are the same. The medical condition is where the body or a part of the body is deprived of adequate oxygen. Similarly, a water body can be deprived of adequate oxygen. Strenuous physical exercise may reduce concentrations of oxygen in the blood as a normal course of activity. Similarly, dissolved oxygen concentrations will fall below $100 \%$ saturation through the process of respiration.

Hypoxia, or anoxia (no oxygen), as considered in this paper, becomes detrimental to aerobic, aquatic organisms when behavioral and physiological responses result in altered behavior or negative impacts, such as reduced growth, loss of reproductive capacity, mortality, reduced biodiversity, and loss of secondary production, including fisheries. There is no single defined concentration at which marine, coastal or estuarine waters become hypoxic to the resident organisms, nor is there consistency in units of oxygen used to express hypoxia.

It is clear that behavioral, physiological, and reproductive responses among taxa differ by taxon, stage of life, and history of exposure to low oxygen of varying levels (Rabalais and Turner, 2001 and chapters therein on taxa from foraminiferans to fishes; Gray et al., 2002). Vaquer-Sunyer and Duarte (2008) more recently surveyed the literature on benthic organisms to evaluate experimentally-derived oxygen thresholds for lethal and sublethal responses to hypoxia. They found an order-of-magnitude variability in the lethal thresholds of oxygen concentrations among benthic marine organisms, which does not lend support for a single universal threshold value. They concluded that the conventional definition of $2 \mathrm{mg} \mathrm{L}^{-1}$ to designate hypoxia waters is below the empirical sublethal and lethal dissolved oxygen thresholds for half of the species tested. Most aquatic ecologists and oceanographers would agree that there is no "conventional" definition of hypoxia and that the relevant thresholds are context-dependent. For example, cod growth is reduced below about $7 \mathrm{mg} \mathrm{L}^{-1}$ or $70 \%$ air saturation (Chabot and Dutil, 1999). Shrimp and fish avoid dissolved oxygen below $2 \mathrm{mg} \mathrm{L}^{-1}$ (approximately 30\% air saturation) in the northern Gulf of Mexico hypoxic zone, while sharks and rays emigrate from the area at dissolved oxygen concentrations below $3 \mathrm{mg} \mathrm{L}^{-1}$ (Rabalais et al., 2001a). For this reason, Rabalais et al. (1991) and others (Renaud et al., 1986) defined hypoxia in the northern Gulf of Mexico as $2 \mathrm{mg} \mathrm{L}^{-1}$ or less based on the behavioral response of most demersal fish, crabs, and shrimp to move away from these waters.

The SCOR WG 128 agreed to consider a general value for hypoxia of $30 \%$ oxygen saturation, or about $2 \mathrm{mg} \mathrm{L}^{-1}$ $\left(1.4 \mathrm{ml} \mathrm{L}^{-1}\right.$ or $\left.63 \mu \mathrm{M}\right)$ (Fig. 2). This value is most relevant as a threshold to coastal waters and organisms that have evolved in normoxic waters without severe hypoxia as an evolutionary stress. However, throughout this article there will be 


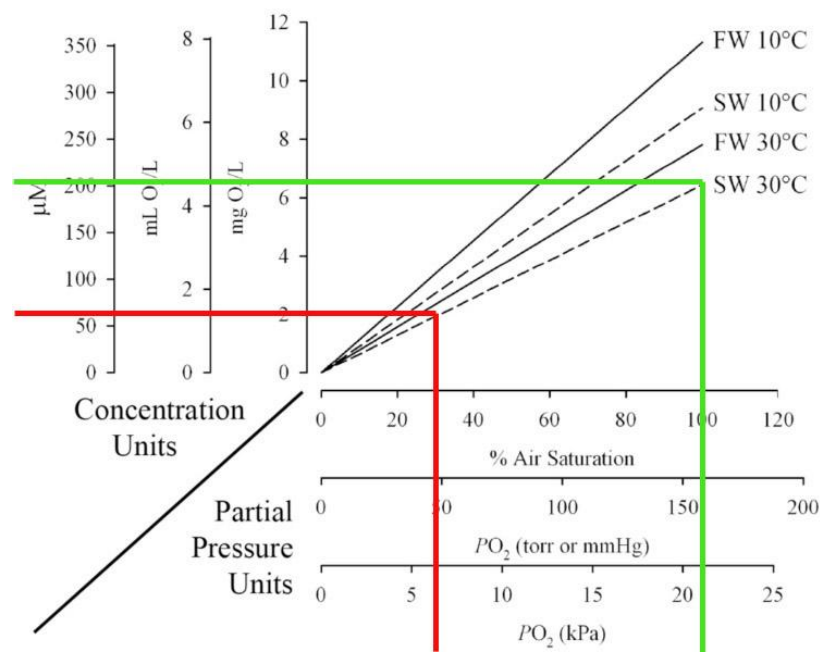

Fig. 2. Nomogram for dissolved oxygen in fresh water (FW) and sea water (SW) at $10^{\circ} \mathrm{C}$ and $30^{\circ} \mathrm{C}$ (modified from Díaz and Breitburg, 2009). Concentration units are on Y-axis, and partial pressure units are on X-axis. Red line is the SCOR definition of hypoxia and green line is the solubility of oxygen in sea water at $30^{\circ} \mathrm{C}$.

multiple definitions and multiple units. Where possible, we will provide suitable conversions and put the terminology in context within the habitats of concern.

The most commonly used units for dissolved oxygen are $\mathrm{mg} \mathrm{L}^{-1}, \mathrm{mlL}^{-1}$, and $\mu \mathrm{M}$, and different concentrations are considered to be the definition of hypoxia (Fig. 2). As mentioned above, a commonly used definition of hypoxia is dissolved oxygen $<2 \mathrm{mg} \mathrm{L}^{-1}$, the equivalent of $1.4 \mathrm{ml} \mathrm{L}^{-1}$ or $63 \mu \mathrm{M}$. Others define hypoxia as $2 \mathrm{ml} \mathrm{L}^{-1}\left(2.8 \mathrm{mg} \mathrm{L}^{-1}\right.$ or $91.4 \mu \mathrm{M})$ (Díaz and Rosenberg, 1995). Physical oceanographers commonly use units of $\mathrm{ml} \mathrm{L}^{-1}$ with a definition of hypoxia at dissolved oxygen $<2 \mathrm{ml} \mathrm{L}^{-1}$. Many aquatic ecologists use $\mathrm{mg} \mathrm{L}^{-1}$, but not all, and at different concentrations to define hypoxia. Environmental and geology scientists agreed that terminology and definitions for oxygen deficiency were fraught with inconsistencies within the scientific groups and definitely among the groups (Tyson and Pearson, 1991b). In fact, Tyson and Pearson (1991b) were the first to "blame" researchers from the northern Gulf of Mexico as the perpetrators of the use of the medical term "hypoxia" to connote low dissolved oxygen waters in marine ecosystems. The symposium coordinated by Tyson and Pearson (1991a) on modern and ancient continental shelf anoxia was the first agreement to disagree about a conventional definition of hypoxia.

The "measure" of hypoxia varies by location around the globe with fewer than $25 \%$ of systems having comprehensive hypoxic area or volume measurements (Díaz and Rosenberg, 2008). The extent of Chesapeake Bay, USA, hypoxia is most often expressed as volume (Hagy et al., 2004) instead of areal extent on the sea bed, which differs from most measures that employ the area of bottom-water hypoxia, e.g., northern Gulf of Mexico, western shelf of India, and Baltic Sea. There is, however, a consistent relationship between volume and areal extent of hypoxia in the mainstem of Chesapeake Bay, USA (Hagy et al., 2004) and the northern Gulf of Mexico (Rabalais et al., 2007a), so that there is some basis for comparison of areas over time (Fig. 3). Whether volume or area is measured, it is important to estimate the extent of hypoxia within a system. This will provide efforts to mitigate hypoxia with a baseline against which progress can be measured, e.g., a goal of $5000 \mathrm{~km}^{2}$ areal extent of hypoxia for the northern Gulf of Mexico on a 5 yr running average by 2015 (Mississippi River/Gulf of Mexico Watershed Nutrient Task Force, 2008).

Area or volume estimates do not adequately describe the total oxygen deficiency of the water column. Dissolved oxygen "condition" can be expressed as a deficit (or a surplus) of oxygen (Justić, 1991a) or as apparent oxygen utilization (AOU), the difference between the measured dissolved oxygen and its equilibrium air saturation concentration $100 \%$ saturation at a known temperature and salinity (Thomas, 2002). Calculations of oxygen deficiency, or AOU, are useful in models that link oxygen budgets with carbon budgets and nutrient loads (e.g., Justić et al., 1996). Changes in nutrient management that can be expressed in altered loads of nitrogen and phosphorus and subsequent changes in carbon and oxygen budgets provide a more comprehensive status of ecosystem condition than area or volume calculations.

For other considerations, such as the effect of hypoxia on benthic macroinfauna, the severity, or period of time that the dissolved oxygen level is below 1 or $2 \mathrm{mg} \mathrm{L}^{-1}$, is a more appropriate measure of hypoxia effects on organisms. For example, the period of exposure to hypoxia is an important factor in the response of the benthic macroinfaunal communities (Fig. 4) (Ritter and Montagna, 1999; Baird et al., 2000; Rabalais et al., 2001b; Baustian and Rabalais, 2009).

Adequate characterization of hypoxia calls for measurements on multiple temporal and spatial scales, which are not always possible because of limited resources. Determination of the extent of hypoxia, usually maximal in summer through early fall, depends on a quasi-synoptic survey over a consistent grid. More frequent mapping of the extent, however, would help ensure that the metric is representative of the system in any given year. A series of years with active tropical storm seasons or abnormal oceanographic currents may skew the area or volume data, such as when the water column is disrupted by a storm within a week or two before the mapping survey (Rabalais et al., 2007a, 2009). Depending on the size of the anticipated area, the costs of multiple mapping ventures may be cost prohibitive. Representative areas, within the larger area affected, may take less time to document thereby reducing the cost, so that greater temporal coverage over the annual cycle may be possible. Finer temporal resolution can be recorded with deployed or profiling instrumentation; finer spatial resolution can be achieved with 


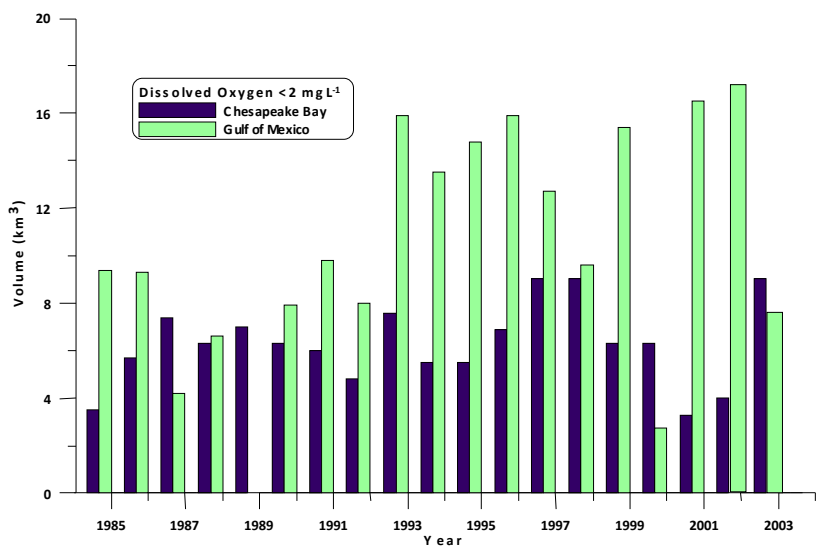

Fig. 3. Comparison of volume data for the Chesapeake Bay (http: //www.eco-check.org/forecast/chesapeake/2009/i) and volume data for Gulf of Mexico, unpubl. data from N. N. Rabalais and R. E. Turner.

towed instrumentation or autonomous underwater vehicles. In most cases, however, the resources are not available for adequate assessments, especially with the appropriate physical, chemical, and biological parameters. A monitoring or assessment program would need to balance the information gained with the funds available to optimize data acquisition.

The hypoxia literature has generated terms, in some cases used inconsistently. Where did the term "dead zone" originate? In Louisiana coastal waters (northern Gulf of Mexico) when the oxygen falls below $2 \mathrm{mg} \mathrm{L}^{-1}$, a shrimper dragging a bottom trawl will not catch any shrimp (or demersal organisms) (Renaud, 1986; Rabalais et al., 2001a). Bottom waters with dissolved oxygen $<2 \mathrm{mg} \mathrm{L}^{-1}$ were first documented with measurements in these waters in August 1972 (Ward et al., 1979) and increasingly in years to come. The shrimpers called these "dead waters" along with another term they coined "red waters" when they encountered blooms of dinoflagellates, suspected to be Noctiluca scintillans or Akashiwo sanguinea. Ecologists examining low oxygen waters in brackish Lake Pontchartrain north of New Orleans, Louisiana would encounter dead blue crabs in traps and dead Rangia clams in the sediments. A reporter from the Baton Rouge, Louisiana, USA, newspaper "The Morning Advocate" asked if these dead areas could be described as a dead zone, and the term first appeared in print in 1981 or 1982. Perhaps there was co-evolution of this term elsewhere during the period of increasing eutrophication and hypoxia in coastal waters in the early 1970s. In their initial paper outlining the increase in areas of hypoxia, Díaz and Rosenberg (1995) did not use the term "dead zone", but it appeared in Díaz (2001), and eventually in the title of their most recent review (Díaz and Rosenberg, 2008). In Chesapeake Bay, USA, where hypoxia has been present since at least the 1920s, Truitt used the term oxygen desert in 1938 to report that "studies are in progress, which aim to show how impor-
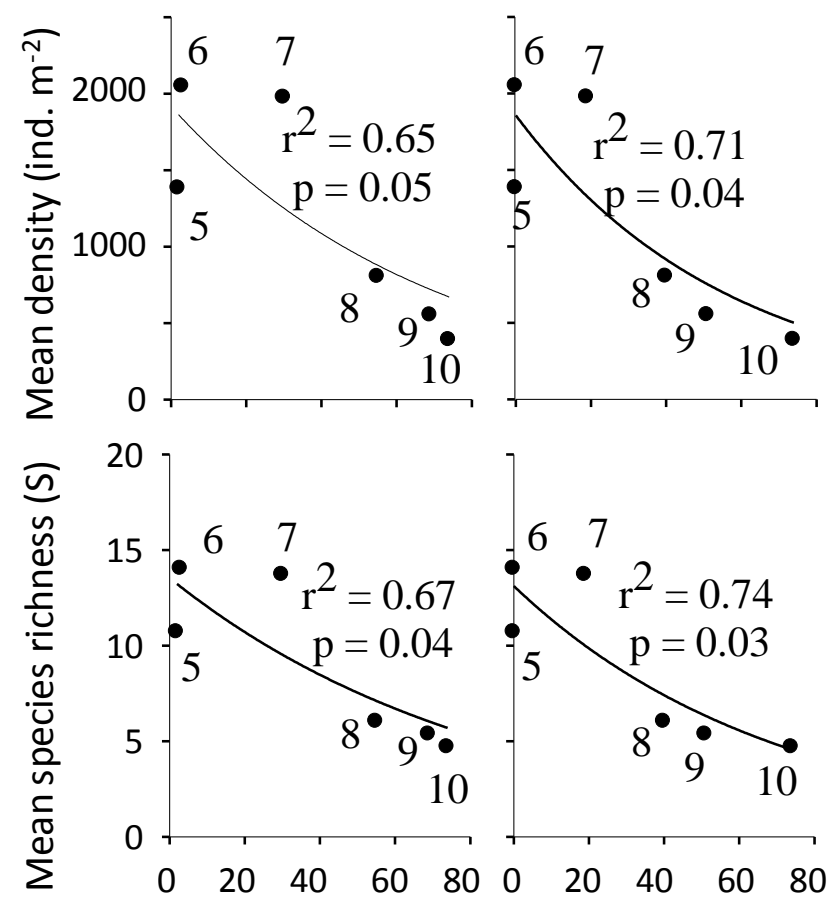

No. Days $\leq 2 \mathrm{mg} \mathrm{L}^{-1}$ No. Days $\leq 1 \mathrm{mg} \mathrm{L}^{-1}$

Fig. 4. Monthly mean density and species richness of macroinfauna from (5) May to (10) October 2004 after increasing exposure to oxygen levels $<2 \mathrm{mg} \mathrm{O}_{2} \mathrm{~L}^{-1}$ and $<1 \mathrm{mg} \mathrm{O}_{2} \mathrm{~L}^{-1}$ (Baustian and Rabalais, 2009).

tant these so-called oxygen deserts are in the economy of the Bay" (Hagy et al., 2004).

In reality the link between hypoxia and "dead zone" best applies to coastal waters where oxygen depletion occurs in otherwise normoxic (oxygenated) waters, with evident migration or mortality of charismatic megafauna (fishes and large invertebrates). Even in the absence of larger fauna, smaller meiofaunal taxa (foraminiferans, nematodes) and microbes persist, such that the regions are not truly "dead". And, the upper water column is fully oxygenated and supports diverse metazoan communities, including productive fisheries. The term "dead zone" is not appropriate for shelf and slope regions with permanent oxygen depletion (oxygen minimum zones or oxygen minimum layers), where fully developed, diverse animal communities with megafauna can occur at concentrations $<2 \mathrm{mg} \mathrm{L}^{-1}$ (Levin, 2003; Gooday et al., 2009a).

\section{Dynamics}

The ecosystems subject to hypoxia, natural, human-induced, or a combination of the two have different dominant time and spatial scales of variability (Fig. 5). Time scales range from hourly and days to seasonal events lasting weeks to months 


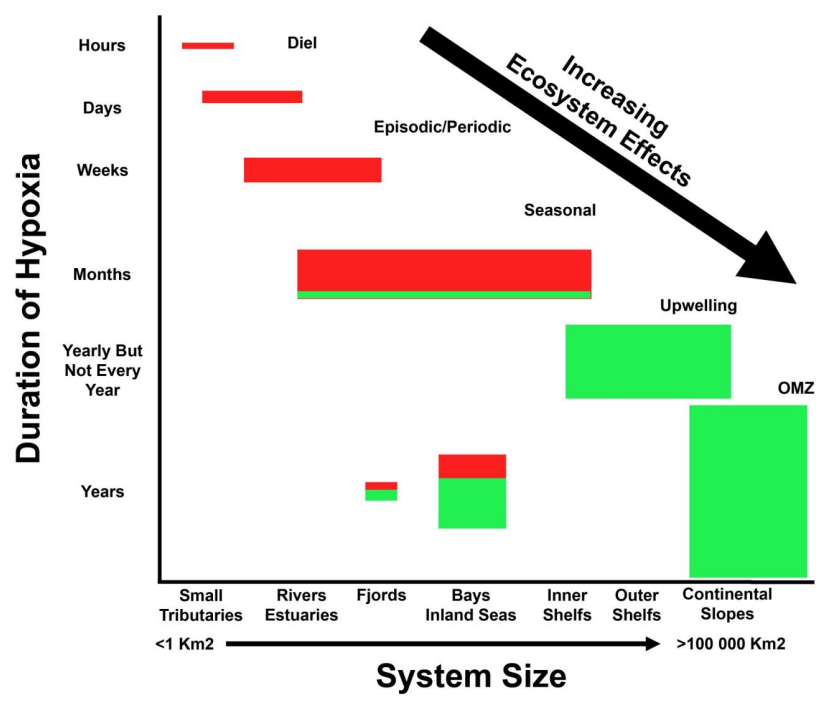

Fig. 5. A synthesis of the variability of temporal and spatial and typological categories for environments with hypoxia. The scales are without units but go from lower to higher. The red and green colors represent the relative ratio of human versus natural influences, respectively. As human influences increase in shallower waters to the coastal ocean, there are more ecosystem effects. Upwelling areas and OMZs are primarily natural, but human activities that indirectly affect global climate change are also affecting these areas. OMZs are the largest, most persistent and natural oxygen-depleted areas in the world's ocean and have the greatest ecosystem changes relative to oxygen conditions, but these are the result of adaptation over geologic time.

or to persistent year-round hypoxia. Near coastal systems linked to climate modes like El Niño Southern Oscillation can also develop severe hypoxia when modes are shifted. The ecosystems in which hypoxia occurs range from inshore estuaries, through the coastal ocean and into ocean waters, over depths of 1- to 2-m in estuaries to 600- to $700-\mathrm{m}$ in the open ocean and vary in physiography, physical processes, organic and nutrient loading, and ecosystem structure. Over this range of ecosystems there is also a pattern in factors that lead to development of hypoxia. Anthropogenic factors are responsible for virtually all hypoxia in estuaries and on inner continental shelves, and have worsened dissolved oxygen conditions in many fjords. Outer shelf and slope hypoxia is all driven by natural factors; however, global climate change (GCC) related to human activities may become a factor in the near future. The richness of temporal and spatial scales helps us understand the basic dynamics of hypoxia, changes in relation to anthropogenic and climate forcing, and the potential for recovery of ecosystems from hypoxia. Overall there is an increase in ecosystem level effects as hypoxia increases in duration and develops over larger areas. These effects range from altered energy flows to disruptions in biogeochemical cycling. Larger systems tend to have hypoxia for longer periods of time, exceptions being fjord like systems.
The combination of physical, chemical, and biological processes that lead to hypoxia differs in magnitude and importance by water body, but there is one basic response. Hypoxia, or oxygen deficiency, occurs when the amount of dissolved oxygen in the water column is decreased by the process of respiration at a faster rate than resupply through airsea exchange, photosynthetic production of oxygen, or advection. Hypoxia is usually associated with a density barrier, caused by temperature, salinity or both that prevents the diffusion of oxygen from a higher concentration layer to a lower concentration layer, but may occur without stratification in a smaller, highly eutrophic system, typical in the form of diel-cycling hypoxia (Flindt et al., 1997; Irigoien, 1999; Tyler et al., 2009), or in larger systems that have intense heterotrophic activity (Verity et al., 2006). Hypoxia may also be "introduced" by advection of low-oxygen source waters. In the eastern Pacific, changes in input of intermediate, lowoxygen water masses contribute to temporal observations of oxygen declines (Chan et al., 2008; Bograd et al., 2008). The Yaquina Bay system in Oregon, USA, experiences episodes of hypoxia when low dissolved oxygen water is advected into the system from the continental shelf (Brown et al., 2007). In Dokai and Ise Bays, Japan (Nakata et al., 1997; Ueda et al., 2000) and Chesapeake Bay, USA (Breitburg, 1992), local winds drive advection of seasonally hypoxic deep waters into shallow areas that reduce shellfish populations.

The carbon source that fuels the respiratory reduction of oxygen most often originates from settled phytoplankton production (autochthonous), but may have a natural terrestrial source (allochthonous) or be from discharge of sewage/industrial waste. Settled phytoplankton production in the form of senescent cells, zooplankton fecal pellets or marine aggregates will settle at a density gradient, as is the case with oxygen minimum zones and subsurface oxygen minima (e.g., off productive river deltas). In other instances the organic carbon sinks to the seabed in shallower waters, where the respiratory decomposition depletes the oxygen in the water column below a strong density gradient.

Human-induced coastal hypoxia is a symptom of eutrophication, the increase in the rate of carbon production and carbon accumulation in an aquatic ecosystem (Nixon, 1995; Grall and Chauvaud, 2002). Eutrophication was initially a description for the natural aging process of freshwater systems, but has more recently been applied to estuarine and coastal systems. As noted above, the source of the increased organic carbon may come from within the system (autochthonous) or from outside the system (allochthonous). This distinction is relevant when management strategies are developed to reverse eutrophication, and its negative symptoms such as hypoxia, and to identify the sources and mechanisms of carbon accumulation. For example, a coastal system could become eutrophic from an increased delivery of organic carbon from terrestrial sources or from nutrientenhanced primary production resulting from increased nutrient loads or from a combination of both sources. Reducing 
organic loading from riverine sources would require different management strategies than that required to reduce nutrient loads. The ability to remediate low oxygen waters is much more successful when organic loads can be identified and reduced than when the organic load is authochthonous resulting from in situ nutrient-enhanced productivity, especially when the increased nutrients derive from nonpoint sources (Kemp et al., 2009).

The causes of eutrophication, and its negative outcome hypoxia, may include changes in physical characteristics of the system such as changes in hydrology, changes in biological interactions such as reduced grazing, or an increase in the input of organic and inorganic nutrients. While the series of causes may include direct natural or anthropogenic carbon enrichment, eutrophication and hypoxia in the coastal ocean and in the 20th and 21st centuries are more often caused by excess nutrients that would otherwise limit the growth of phytoplankton. There is little doubt that there have been ecosystem-level changes in coastal systems as a result of eutrophication and associated hypoxia (Baden et al., 1990a; Bakan and Buyukgungor, 2000; Rabalais and Turner, 2001; Wang 2006; Turner et al., 2008; Ekau et al., 2009; Kemp et al., 2009; Levin et al., 2009a).

Coastal systems include estuaries and continental shelf waters that extend from the tidally influenced areas to the barrier island shoreface on to the edge of the continental shelf at $100 \mathrm{~m}$ water depth. Estuaries vary in physiography, but those most conducive to the formation of hypoxia are characterized by longer water residence times that allow for accumulation of carbon and respiratory depletion of oxygen. Stratification is also a key factor for the development and maintenance of hypoxia in an estuary, for example Chesapeake Bay, USA, (Kemp et al., 2005), Ardbear Salt Lake, Ireland (Henry et al., 2008), or Wilson Inlet, Australia (Brearley, 2005). Some estuaries, especially those with expanses of macroalgae or sea grasses, will have a diel cycle of high oxygen saturation during daylight photosynthesis but substantially reduced oxygen saturation during night or approaching dawn as respiratory consumption of oxygen exceeds the resupply from air-water exchange. Vegetated estuaries, however, may develop hypoxia as a result of nutrient driven increases in phytoplankton biomass, epiphytic algae, or floating macroalgae (Schramm, 1999; Berezina, 2008).

Fjords such as Saanich Inlet, British Columbia, Canada are naturally susceptible to hypoxia and anoxia because water residence time is long, sills may prevent exchange with oceanic waters, and thermal stratification will form in warmer months preventing reoxygenation from surface waters (Tunnicliffe, 1981). Fjords, however, are also subject to excess nutrients and carbon leading to human-caused hypoxia in a susceptible environment, for example Hood Canal in Puget Sound, USA (Parker-Stetter and Horne, 2008) and Himmerfjarden, Sweden (Savage et al., 2002).

Human-caused coastal hypoxia is most likely to occur within the 100-m isobath (Rabalais, 2004), for example the northern Adriatic Sea (Justić et al., 1987) or the East China Sea (Li et al., 2002; Chen et al., 2007). Often, shallower waters on the open coast are not conducive to the carbon accumulation that supports hypoxia because turbidity caused by resuspension of sediments or delivery of sediments from coastal rivers limits the production of phytoplankton. However, at times during unusual calm weather events large areas of hypoxia can develop, as have been documented on the inner continental shelf of the New York bight, USA (Swanson and Sindermann, 1979; Boesch and Rabalais, 1991) and the west coast of Florida, USA (FWRI, 2005). Deeper, more open, coastal waters are not as conducive to eutrophicationcaused hypoxia as intermediate-depth waters, because nutrients are depleted with distance offshore, less primary production occurs, and less organic matter is exported from surface waters, as a result of either production or settling distance. Along continental margins deeper than $100 \mathrm{~m}$, hypoxia is most likely to occur as a response to coastal upwelling driven primary production or the advection of deeper water hypoxia closer to shore. Examples are shorelines along eastern boundary currents, such as the California Current System off Oregon and Washington (USA) states (Grantham et al., 2004; Chan et al., 2008), the Humboldt Current off Chile and Peru (Pizarro et al., 2002), or the Benguela Current off the west coast of Africa (O'Toole, et al., 2001; Arntz et al., 2006).

Many semi-enclosed seas - entire basins or portions of systems - are conducive to the process of eutrophication because of a physiography that enhances water residence times and because they receive land-based runoff or atmospheric deposition that is less likely to dilute as quickly as on an open coast (Rabalais and Gilbert, 2009). Coastal systems adjacent to many large rivers have received increasingly nutrientrich discharges. Swift currents that move materials away from the river discharge and that do not permit the development of stratification are not conducive to the accumulation of biomass or depletion of oxygen, for example in the Amazon and Orinoco plumes. The Bay of Bengal sustains a strong potential for impacts from riverine nutrient loads due to the very high nutrient yields in its catchment basins, e.g., via the Ganges/Brahmaputra, Godavari and Mahanadi rivers. The Bay of Bengal is the most open of all the systems receiving high nutrient inputs, with no physical barriers separating its coastal zone from the open ocean. In this case, the rate of exchange between coastal and open ocean water masses will dictate the system's response to the riverine loads. Off east India in the Bay of Bengal hypoxic conditions $\left(<1.42 \mathrm{ml} \mathrm{L}^{-1}\right)$ are persistent on the outer shelf beyond $100 \mathrm{~m}$ and the oxygen minimum zone $\left(<0.5 \mathrm{ml} \mathrm{L}^{-1}\right)$ is present from $150 \mathrm{~m}$ to about 500 or $600 \mathrm{~m}$ (Rao et al., 1994; Helly and Levin, 2004). Similar ocean circulation processes off the Changjiang (Yantze River) and high turbidity in the plume of the Huanghe (Yellow River), China were once thought to be reasons why hypoxia did not develop in those coastal systems. Incipient indications of the beginning 
of symptoms of cultural eutrophication are becoming evident at the terminus of both these systems as nutrient loads increased (Zhang et al., 1999; Liu et al., 2003). Presently, there is a well-documented area of hypoxia off the Changjiang in summer (Li et al., 2002). There is increasing likelihood that more and more coastal systems, where the physical conditions are appropriate, will become eutrophic, especially in developing countries.

The volume of freshwater discharge, exclusive of the nutrient load, can influence residence time, stratification, turbidity and nutrient dilution. High flow years of the Mississippi River result in intensified stratification on the continental shelf, higher chlorophyll biomass and more widespread bottom-water hypoxia (Rabalais et al., 1998). Within the Hudson River estuary higher discharge years result in lower residence time, increased turbidity, less stratification, lower primary production and less eutrophication (Howarth et al., 2000). The same Hudson River discharge onto the continental shelf of the New York bight, however, would be expected to have similar results as Mississippi River outflow with increased stratification, high chlorophyll biomass and bottomwater hypoxia. Low oxygen events and shellfish mortalities have been reported from the New York bight historically and during an extreme episode in 1976 (Swanson and Sindermann, 1979; Whitledge, 1985).

The temporal scales of hypoxia vary from hourly to decadal or longer. For small estuaries hypoxia lasting from hours to days is common. Water circulation patterns may cause advection of hypoxic waters into shallower areas on tidal cycles (Breitburg, 1992), or weather patterns such as storm winds may disrupt stratification over short time scales (Rabalais et al., 2007). Respiration rates in high chlorophyll biomass or vegetated estuaries are diel with the balance between photosynthesis and respiration shifting during dark hours (Tyler et al., 2009). As systems become larger, hypoxia tends to become a seasonal event lasting weeks to months. Long-term freshwater discharge, nutrient loads, and physical conditions in most coastal areas are seasonal and recur on an annual basis with the development and maintenance of hypoxia responding to these biological and physical dynamics. Depending on the susceptibility of a system, it may develop persistent year-round hypoxia, as is the case with the eutrophication-aggravated hypoxia of the Baltic Sea (Conley et al., 2009a). Hypoxia in near coastal systems close to oceanic systems will likely change as decadal cycles like El Niño Southern Oscillation shift (Fuenzalida et al., 2009).

\section{Oxygen minimum zones}

Similar to the coastal hypoxia debate, there is no consensus on what oxygen concentration defines oxygen minimum zones (OMZs). This term is generally used to refer to permanent midwater, low-oxygen features in the eastern Pacific, off western Africa and the northern Indian Ocean (Kamykowski and Zentara, 1990; Paulmier and Ruiz-Pino, 2009). Upper oxygen thresholds for $\mathrm{OMZ}$ regions range from dissolved oxygen of $9 \mu \mathrm{mol} \mathrm{kg} \mathrm{k}^{-1}\left(0.2 \mathrm{ml} \mathrm{L}^{-1}\right)$ (Kamykowski and Zentara, 1990), to $20 \mu \mathrm{mol} \mathrm{kg}{ }^{-1}\left(0.5 \mathrm{ml} \mathrm{L}^{-1}\right)$ (Helly and Levin, 2004; Fuenzalida et al., 2009; Paulmier and Ruiz-Pino, $2009)$, and to $45 \mu \mathrm{mol} \mathrm{kg}^{-1}\left(1.0 \mathrm{ml} \mathrm{L}^{-1}\right)$ or $90 \mu \mathrm{mol} \mathrm{g}^{-1}$ $\left(2.0 \mathrm{ml} \mathrm{L}^{-1}\right)$ (Karstensen et al., 2008). The term "oxygen minimum layer" is sometimes used to refer to midwater layers exhibiting reduced oxygen relative to waters above and below. Such layers are ubiquitous in the global ocean due to isolation from sources of oxygenation, but often do not reach "hypoxic" oxygen levels. For example, in the central Gulf of Mexico and eastern North Atlantic Ocean oxygen levels are depressed but not seriously low (Conseil, 1936; Richards, 1957; Kamykowski and Zentara, 1990).

A series of terms describes the overall oxygen conditions within OMZs. Anoxic refers to waters with virtually no oxygen. Often high levels of sulfide are released into the water column, as in the Black Sea where anoxic conditions extend to within 100-200 $\mathrm{m}$ of the surface (Richards, 1965; Konovalov and Murray, 2001). When oxygen is detectable but below about $4.5 \mu \mathrm{mol} \mathrm{kg}-1$ ( $\left(0.1 \mathrm{ml} \mathrm{L}^{-1}\right)$ the water is suboxic, a threshold determined from nitrate reduction to nitrite (Karstensen et al., 2008).

By any definition, oceanic OMZs are the largest low dissolved oxygen areas on earth and cover about 30 million $\mathrm{km}^{2}$ of open ocean, much of which is not near the continental margins (Paulmier and Ruiz-Pino, 2009). The principal factors that lead to the formation of OMZs are high surface productivity, old water mass age, and limited circulation. Isolation of intermediate water masses leads to thicker OMZs. In addition, upwelling associated with continental margins leads to higher productivity and greater oxygen demand and also contributes to a thicker OMZ and lower oxygen concentrations (Helly and Levin, 2004). OMZs are widespread and stable oceanic features occurring at intermediate depths (typically 100-1200 m). They persist for long periods of time (at greater than decadal scales), but have variable upper and lower boundaries that are controlled by natural processes and cycles (Wyrtki, 1966; Kamykowski and Zentara, 1990; Helly and Levin, 2004). This may be about to change as recently expanding trends have been noticed in several Pacific OMZs that are linked to GCC (Fig. 6) (Mataer et al., 2000; Stramma et al., 2008). Minimum oxygen values typically occur from 300 to $500 \mathrm{~m}$ in the southeastern Pacific and Arabian Sea with lowest oxygen declining to $<1 \mu \mathrm{mol} \mathrm{kg} \mathrm{k}^{-1}$. Minimum oxygen concentrations occur deeper in the northeastern Pacific (600-1000 m) (Fuenzalida et al., 2009; Paulmier and Ruiz-Pino, 2009). The eastern Atlantic has relatively high oxygen minimum values of about $17 \mu \mathrm{mol} \mathrm{kg}{ }^{-1}$ in the South Atlantic and $>40 \mu \mathrm{mol} \mathrm{kg}{ }^{-1}$ in the North Atlantic (Karstensen et al., 2008). Globally, where OMZs contact the bottom, about $1148000 \mathrm{~km}^{2}$ of continental margin sea floor is estimated to have bottom water oxygen concentrations $<0.5 \mathrm{ml} \mathrm{L}^{-1}$. Using the stricter definition 


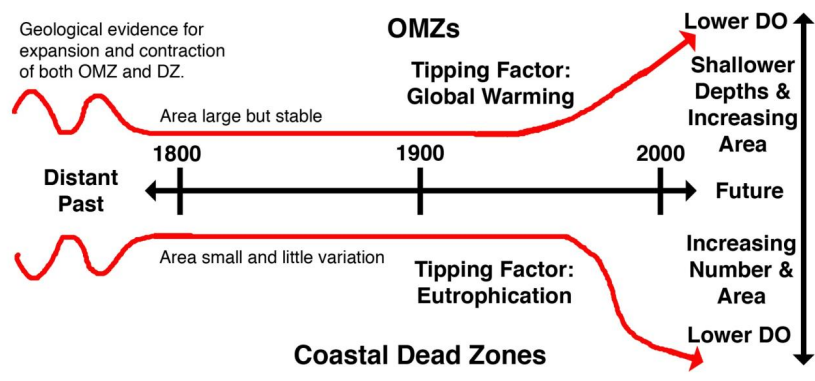

Fig. 6. Comparison of the history of oxygen minimum zones (OMZs) and coastal dead zones (DZ) from the past into the future. Both are expanding from anthropogenic activities, but from different processes. OMZs are expanding from global warming and DZs from eutrophication.

of $<0.2 \mathrm{ml} \mathrm{L}^{-1}$, about $764000 \mathrm{~km}^{2}$ of seafloor are affected (Helly and Levin, 2004). Oxygen minimum zones often occur beneath upwelling regions, and upwelling-induced productivity is a primary contributor to persistent hypoxia. However, inshore regions subject to seasonal or episodic upwelling can also experience severe hypoxia as deep-water nutrients are added to surface waters increasing production that eventually sinks and decomposes. Hypoxia associated with this type of coastal upwelling is not as long-lived and stable as that associated with OMZs. Upwelling can interact strongly with low-oxygen water masses (OMZs) to produce intense shelf hypoxia; this is observed off of Oregon, USA (Grantham et al., 2004) and Chile (Fuenzalida et al., 2009), Africa (Monteiro et al., 2008) and India (Naqvi et al., 2000).

Demersal and pelagic fisheries benefit from the enhanced organic production associated with upwelling when oxygen concentrations remain high. For example, demersal fisheries (scallop, hake, and octopus) flourish under better oxygenated El Niño conditions off the Chilean upwelling system. This results from the convergence of a combination of land and ocean processes that make these upwellinginfluenced coastal zones highly productive (Pauly and Christensen, 1995; Escribano et al., 2004; Chavez et al., 2003). On the other hand, the resulting oxygen depletion, whether from mid-ocean OMZs or coastal upwelling or their interaction, affects midwater plankton and pelagic organisms creating areas of low biodiversity, and hostile environmental conditions for many commercially valued fisheries resources (Graco et al., 2006; Ekau et al., 2009). Monsoon-driven upwelling along the western coast of India migrates onshore and offshore depending on winds and currents. When pushed onshore, there are declining catches of fishes and prawns and diminished demersal fisheries (Banse, 1959, 1968; Kurian et al., 2009). Recent intensification of the severity of low oxygen in the coastal component of this upwelling zone is most likely due to a combination of climate change and humansourced nutrients (Naqvi et al., 2006b) that will further impact the fisheries.
Where OMZs and upwelling zones impinge on the seafloor of continental slopes and shelves, and sea mounts, specialized low biodiversity communities have evolved to survive at dissolved oxygen concentrations as low as $0.1 \mathrm{mg} \mathrm{L}^{-1}$ or less (Graham, 1990; Childress and Seibel, 1998; Sakko, 1998; Levin, 2002; Levin et al., 2000, 2009a). These OMZ assemblages differ from shallower communities exposed to seasonal or episodic hypoxia in having much lower oxygen tolerance thresholds, morphological adaptations to maximize respiratory surface, specialist rather than opportunistic lifestyles, and potential to utilize chemosynthesis-based nutritional pathways (Levin, 2003).

While there are similarities and differences in the benthic response to both natural and human-induced hypoxia, a key difference between them is the time-scales of their development (Fig. 6). OMZ and upwelling-related hypoxia have been stable and persistent features of the global oceans for centuries (Helly and Levin, 2004). Historically, humaninduced hypoxia appears to have been confined to highly modified watersheds or harbors and was not a global phenomenon (for the contrast in time, see Brongersma-Sanders, 1957; Díaz and Rosenberg, 2008). In the relatively short period from about 1950 to today, in response to increasing reliance on industrial fertilizers to feed an ever expanding population, humans have drastically altered global nitrogen cycling and coastal primary production to the point that now human-induced hypoxia has become a principal stressor of coastal systems on a global scale (Galloway et al., 2004, 2008). The relationship between increased fertilizer use, which leads to increased nutrient loading and stimulated phytoplankton primary production and biomass accumulation, and the subsequent increase in the number of human-induced hypoxic systems lagged about $10 \mathrm{yr}$ (Fig. 6). This is the period of time it took for excess organic matter from primary production to build up and overwhelm an ecosystem's assimilative capacity to the detriment of higher trophic levels and the benefit of microbes (Cloern, 2001; Díaz and Rosenberg, 2008; Turner et al., 2008). Similarly, when OMZs contact the bottom, organic matter increases and oxygen concentrations becomes suboxic, high microbial biomass can accumulate (Gallardo, 1977).

The upper limit of the OMZ can undergo large vertical excursions in the southeastern Pacific (Helly and Levin, 2004; Fuenzalida et al., 2009) and in the Arabian Sea (Brand and Griffiths, 2009) with major implications for fisheries and biogeochemical cycling. Forcing can be linked to seasonal winds (Brand and Griffiths, 2009) and rainfall and river runoff (Escribano et al., 2004), El Niño Southern Oscillation cycles (Fuenzalida et al., 2009), or longer term trends (Bograd et al., 2008). OMZ shoaling in the eastern tropical Pacific has compressed the depth distribution of tropical pelagic marlins, sailfish, and tunas into a narrow surface layer of oxic water about 50 to $100 \mathrm{~m}$ thick (Prince and Goodyear, 2006). The hypoxic water is a lower habitat boundary in the Pacific, but not in the western North Atlantic, where oxygen is not as 
low and is not limiting. The high-performance physiology of these tropical pelagic fishes leads to a relatively high hypoxic threshold (about $3.5 \mathrm{ml} \mathrm{L}^{-1}$, Brill, 1996), and makes these species dependent on an oxygen rich environment, which in the eastern tropical Pacific exists only near the surface. Eastern Pacific and eastern Atlantic sailfish are larger than those in western North Atlantic, where the OMZ is much deeper or absent. Larger sizes may reflect increased prey encounters within the compressed habitat, but habitat compression also makes them more vulnerable to over-exploitation. Predictably, the long-term landings of tropical pelagic tunas from areas of habitat compression have been far greater than in surrounding areas (Prince and Goodyear, 2006). For biogeochemical cycling, OMZs are the main areas of nitrogen loss in the form of $\mathrm{N}_{2}$ and $\mathrm{N}_{2} \mathrm{O}$ to the atmosphere through denitrification and anaerobic ammonium oxidation (anammox) and could even indirectly mitigate the oceanic biological sequestration of $\mathrm{CO}_{2}$ (Paulmier and Ruiz-Pino, 2009).

\section{Upwelling areas}

Upwelling systems are typical of eastern boundary currents along the Pacific coast of Central and South America, in North America (California, Oregon), the eastern Atlantic Ocean off the southwestern and northwestern coasts of Africa, and the eastern Arabian Sea off India. Per unit area these upwelling systems are among the most productive marine ecosystems in the global ocean (Ryther, 1996) and, while occurring over less than $0.5 \%$ of the ocean area, are responsible for $7 \%$ of the global fishery yield (Pauly and Christensen, 1995). Unlike the persistent OMZs, upwelling systems tend to be seasonal and cycle through phases of increased nutrient availability, high primary and secondary productivity, which in turn affect biogeochemical cycling (Farías and Cornejo, 2007). Much of the organic carbon produced by the upwelled nutrients is not grazed and sinks below the pycnocline where respiratory processes deplete oxygen. These oxygen deficient areas form along continental shelf margins leading to hypoxia or anoxia on the continental shelf. The trophic status of upwelling systems would be considered "eutrophic" (an organic carbon supply of 300$500 \mathrm{~g} \mathrm{C} \mathrm{m}^{-2} \mathrm{yr}^{-1}$, as defined by Nixon, 1995), but upwelling systems are not thought to be affected by anthropogenic eutrophication. Thus the hypoxia that develops would be considered the result of natural processes, not aggravated directly by human activity. However there is growing evidence that GCC has, in part, altered some upwelling areas (Whitney et al., 2007; Bograd et al., 2008; Cheung et al., 2010).

The upwelling system off the western Indian shelf, however, may be the first to be influenced by anthropogenic eutrophication. The western Indian shelf typically experiences moderate upwelling during June through November, but was particularly well developed in September through October in 1999 (Naqvi et al., 2000). The cold, saline up- welled water is usually capped by a 5- to 10 -m thick warm, lower-salinity layer arising from high land runoff and local precipitation, contributing to the stratification and its intensification. The upwelled water is derived from the shelf break, which has a dissolved oxygen concentration of about $0.5 \mathrm{ml} \mathrm{L}^{-1}(22 \mu \mathrm{M})$ at $15^{\circ} \mathrm{N}$ latitude. Once impinged on the shelf, the dissolved oxygen content is quickly depleted to near anoxia by the decomposition of the high primary production (500 $\mathrm{m} \mathrm{C} \mathrm{m}^{-3} \mathrm{~d}^{-1}$ ) stimulated by the upwelled nutrients. In the 1999 event, hypoxia $\left(0.5 \mathrm{ml} \mathrm{L}^{-1}\right)$ covered an area of the shelf of about $180000 \mathrm{~km}^{2}$, which is a large expression of upwelling on an eastern boundary. Naqvi et al. (2000) indicated that the severity of the 1999 event was possibly related to increasing anthropogenic nutrients to the western shelf of India.

When an upwelling is associated with an OMZ, hypoxic water is also upwelled onto the continental margin during appropriate oceanographic current conditions. In either case, direct advection of low dissolved oxygen water or in situ draw down of oxygen by microbial decomposition of organic matter, continental shelf pelagic and benthic fauna are subject to the same risks from hypoxia or anoxia as anthropogenic related shelf hypoxia. The extent of anoxia is a function of oceanographic forcing factors and accumulation of organic matter, as is the generation of toxic $\mathrm{H}_{2} \mathrm{~S}$ gas (Weeks et al., 2002; Emeis et al., 2004; Naqvi et al., 2006a). Both the Humboldt (Escribano and Schneider, 2007) and Benguela Current systems (Chapman and Shannon, 1985; Monteiro et al., 2008) develop extensive severe hypoxia and anoxia that adversely affects pelagic and benthic species (Arntz et al., 2006). For example, in 1994, persistent and pronounced hypoxic conditions developed off the coast of central and northern Namibia over much of the continental shelf. These conditions displaced juvenile Cape hake (Merluccius capensis) offshore from their typical inshore habitat, subjecting them to heavy mortalities from predation by larger hake and from commercial trawling (Hamukuaya et al., 1998). Lobsters were trapped by low oxygen waters advecting onshore with mass mortality events (Cockcroft, 2001).

\section{Changes in climate and circulation at the interface of coastal and oxygen-poor oceanic waters}

Changes in ocean circulation may also have a strong effect on the supply of oxygen to the bottom waters of affected shorelines. Five decades of available inner-shelf observations along the Oregon (USA) Pacific coast showed little evidence of severe inner shelf hypoxia $\left(<0.5 \mathrm{ml} \mathrm{L}^{-1}\right.$ or $0.7 \mathrm{mg} \mathrm{L}^{-1}$; Chan et al., 2008). More recent studies documented hypoxia along the Oregon and Washington coasts beginning in 2000 related to basin-scale fluctuations in atmosphere-ocean processes that altered the oxygen content of upwelled water, the intensity of upwelling wind stress, and productivitydriven increases in coastal respiration (Grantham et al., 2004; 
Bakun and Weeks, 2004; Bograd et al., 2008). Strong persistent upwelling winds fueled intense biological production, leading to hypoxia in near-bottom waters. These changes were attributed to GCC and shifting of north winds in summer (Chan et al., 2008). Beginning in 2006 there was an intensification of severe inner shelf hypoxia associated with the California Coastal Current along the west coast of the US and upwelling-favorable winds. At this point, hypoxia was evident at $<50 \mathrm{~m}$ water depth on the inner shelf within $2 \mathrm{~km}$ of shore. The hypoxia expanded across broad sections of the central Oregon coast from $44.15^{\circ} \mathrm{N}$ to $45.00^{\circ} \mathrm{N}$ and extended from the shelf break to the inner shelf over a $3000 \mathrm{~km}^{2}$ area. Mass mortality of crabs and other megafauna was observed, along with loss of rockfish (Sebastes spp.) and growth of bacterial mats. The absence of prior records of anoxia or mass mortality of the fauna from the Oregon shelf suggests the fauna had no pre-adaption to hypoxia and points to a possible link of these events with GCC. Global warming has altered ocean atmospheric coupling with strong effects on upwelling wind stress as well as respiration that may influence oxygen saturation of source waters (Bakun, 1990; Keeling and Garcia, 2004). An alternate consequence related to intensification of upwelling wind stress would be the cooling of shallow coastal areas from the advection of the cold, nutrient rich waters (Bakun, 1990).

The shifts in circulation along the Oregon/Washington coast point to the strong coupling with atmospheric processes that cause shifts in wind-driven upwelling systems, which can lead to hypoxia. This increases ecosystem vulnerability to modulations of upwelling from climate warming (Barth et al., 2007; McGregor et al., 2007) and becomes a primary driving force of fisheries yield. An example would be the decadal variation in the intensity and sporadic occurrence of mass mortalities of rock lobsters (Jasus lanlandii) along the coast of South Africa associated with the Benguela Current system. In the 1990s, five "walkout" events stranded about 2260 tons of lobster and caused severe economic impacts on the lobster fishery (Cockcroft, 2001). Inherent in these processes is a rise in discontinuous, unexpected, and aperiodic hypoxia in the California Coastal Current, Humboldt Current, and Benguela Current Large Marine Ecosystems, and elsewhere as shallow coastal shelf ecosystems subject to productive upwelling systems are also exposed to hypoxia (Escribano and Schneider, 2007; Chan et al., 2008; Monteiro et al., 2008).

In another example, the deep waters in the Lower St. Lawrence estuary are presently hypoxic, with low oxygen waters $\left(<2.0 \mathrm{mg} \mathrm{L}^{-1}\right)$ covering a $1300 \mathrm{~km}^{2}$ area (Fig. 7) (Gilbert et al., 2005, 2007). Historical data indicate that dissolved oxygen concentrations in the 300 to $355 \mathrm{~m}$ depth range decreased by nearly $50 \%$ over the last $70 \mathrm{yr}$, from $4.0 \mathrm{mg} \mathrm{L}^{-1}$ in the $1930 \mathrm{~s}$ to an average of $2.1 \mathrm{mg} \mathrm{L}^{-1}$ for 1984-2003 (Gilbert et al., 2005). Two-thirds of the $1.9 \mathrm{mg} \mathrm{L}^{-1}$ oxygen decline and a concomitant $1.7^{\circ} \mathrm{C}$ warming of the bottom waters are attributed to a decreasing pro-

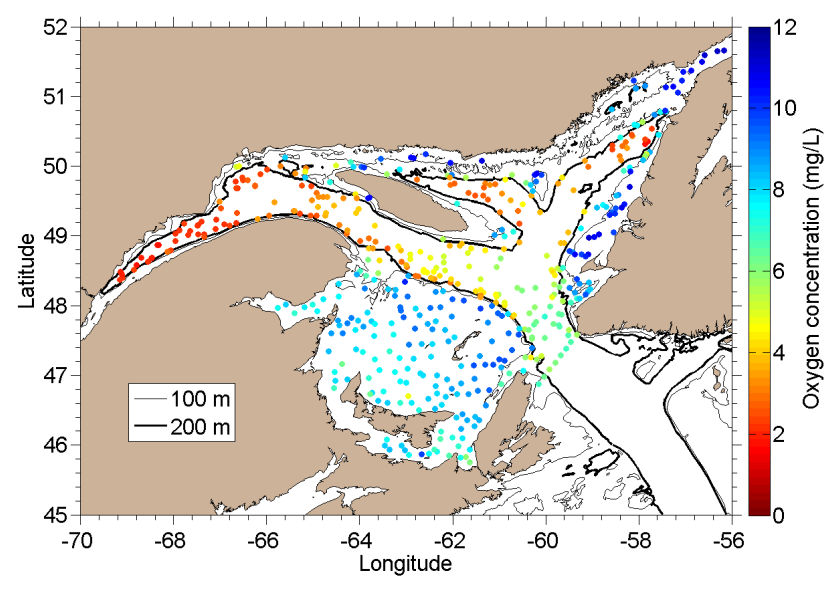

Fig. 7. Near-bottom oxygen concentration $\left(\mathrm{mg} \mathrm{L}^{-1}\right)$ measured during the 2004 (southern and northern Gulf of St. Lawrence) and 2005 (only the northern part of the Gulf of St. Lawrence) fish stock assessment surveys. Modified from data published in Gilbert et al. (2007). Used with permission from Société Provancher.

portion of oxygen-rich Labrador Current Water in the water mass entering the Gulf of St. Lawrence from the northwest Atlantic Ocean. The remaining one-third of the change could be due to increased oxygen consumption resulting from increased primary production and greater carbon flux to the deep water (see Coastal eutrophication and hypoxia below). The organic carbon content and the accumulation rates of dinoflagellate cysts and benthic foraminiferans have increased over the last four decades, and a shift in the stable carbon isotope signature of the organic carbon suggests enhanced accumulation of marine organic carbon (Thibodeau et al., 2006). As in the northern Gulf of Mexico, Long Island Sound, and Chesapeake Bay (Sen Gupta et al., 1996; Osterman et al., 2005, 2009; Rabalais et al., 2007b), there has been a shift in dominance towards benthic foraminifera that are tolerant to low dissolved oxygen concentrations and those that prefer high organic content of sediments. Similar species dominance occurs among Foraminifera associated with OMZs and upwelling areas (Panchang et al., 2006; Gooday et al., 2009a).

\section{Enclosed and semi-enclosed deep basins}

There have been periods through the geologic record when hypoxia and anoxia were widespread in ocean basins (Tyson and Pearson, 1991a; Wilson and Norris, 2001; Neretin, 2006). For example, an oceanic anoxic event that marked the Permian-Triassic boundary was coincident with mass extinction in both the marine and terrestrial environments, which may have been driven by the release of hydrogen sulfide from the deep waters of anoxic ocean basins (Kump et al., 2005). Today there are a number of isolated ocean basins that are hypoxic/anoxic due to restricted water circulation 
combined with high primary production in surface waters. Among them are the permanently anoxic Black Sea and Cariaco Basin and several smaller basins along the California, USA, coast (Santa Monica, Santa Barbara, San Pedro, San Nicolas basins) that are reoxygenated periodically (Berelson, 1991). Flow variation of the California Undercurrent ventilates the San Pedro and San Nicolas basins, enriching them with oxygen and allowing for recolonization of organisms until anoxic conditions return (Savrda et al., 1984). Some deep fjords that are permanently anoxic, such as the Framvaren, Norway, have a similar biogeochemistry to oceanic anoxic basins (Skei, 1983). But, most fjords have some seasonal deep-water renewal, which keeps them from being anoxic all year.

In the case of the Black Sea, anoxic conditions occur beneath $100-200 \mathrm{~m}$ of oxygenated surface waters in the open sea area. The restricted connection with the Mediterranean Sea, strong stratification, and geomorphology make the Black Sea a sink for nutrients and other materials (Richards, 1965; McQuatters-Gollop et al., 2008). The persistent anoxic basin in the open Black Sea is the largest naturally occurring anoxic area on earth. It covers about $75 \%$ of the basin's area and is distinct from and not related to the eutrophicationrelated seasonal hypoxia that has occurred on the shallow northwestern continental shelf (Tolmazin, 1985; Zaitsev, 1992; Mee, 2001, 2006). The impact of eutrophication on the open Black Sea has been considerably less severe than that occurring in the shelf area. But, there is also evidence that the suboxic zone of the open Black Sea enlarged and expanded towards the surface by about $10 \mathrm{~m}$ since the 1970s (Oguz, 2005). These changes in the anoxic basin appear to be related to both GCC and nutrient loading factors (McQuattersGollop et al., 2008; Oguz, 2005).

The Cariaco Basin also supports a large persistent anoxic area below $250 \mathrm{~m}$. Restricted circulation and high primary production within the basin $\left(\sim 500 \mathrm{gC} \mathrm{m}^{-2} \mathrm{yr}^{-1}\right)$ support this anoxia (Müller-Karger et al., 2001, 2004). This naturally occurring anoxic basin allows for sediments to be deposited without bioturbation, forming varves of alternating light and dark color, which correspond to the dry or rainy season (Haug et al., 2001). Because of water column anoxia, basins like the Cariaco have a unique biogeochemistry that resembles that of anaerobic sediments (Madrid et al., 2001; Stoeck et al., 2003). Bacteria inhabit both the oxic and anoxic portions of the water column, with a maximum in the suboxic interface (Taylor et al., 2001). The suboxic layer oscillates between 200 and $300 \mathrm{~m}$ in the Cariaco Basin and 150 to $200 \mathrm{~m}$ in the Black Sea (Oguz, 2005).

\section{Coastal eutrophication and hypoxia}

\subsection{Water column processes}

Reactive nitrogen $(\mathrm{Nr})$ has increased substantially over the last century through artificial fixation of nitrogen into fertilizers, the emission of nitrogen oxides from the consumption of fossil fuels, and the transformation of reduced forms through volatilization processes. The creation of reactive nitrogen increased by a factor of 20 since 1860 to the 1995 level of anthropogenic production of $\mathrm{Nr}$ of $\sim 150-165 \mathrm{Tg} \mathrm{N} \mathrm{yr}^{-1}$ (Galloway and Cowling, 2002). The change was enormous, and it increased further to $187 \mathrm{Tg} \mathrm{N} \mathrm{yr}^{-1}$ in 2005 (Galloway et al., 2008). Phosphorus additions to the landscape enter via fertilizers manufactured from mined phosphorus, animal manures, and waste products from animals supplemented with phosphorus-enriched feed, and enter rivers and streams via wastewater effluents and soil erosion. Phosphorus is accumulating in the soil with important implications for increased runoff from the landscape to surface waters (Bennett et al., 2001). Increased flux of phosphorus eroded from the landscape or carried in wastewater effluents to the world's rivers has increased the global flux of phosphorus to the oceans almost 3-fold above historic levels of $\sim 8 \mathrm{Tg} \mathrm{Pyr}^{-1}$ to end of the 20th century loadings of $\sim 22 \mathrm{Tg} \mathrm{Pyr}^{-1}$ (Bennett et al., 2001). Accumulation in landscapes of developed countries is declining somewhat, but that of developing countries is increasing (Bennett et al., 2001). Compared to increased runoff of nitrogen and phosphorus, river concentration or loads or both of dissolved silicon have remained the same or decreased, so that the relative proportions of silicon to nitrogen and silicon to phosphorus in river effluents have decreased over time (Justić et al., 1995a, b; Humborg et al., 1997; Turner et al., 2003). The result is increased primary production where nitrogen or phosphorus or both were limiting, and perhaps a limitation of diatom growth where the relative proportion of silicate to nitrogen approached the Redfield ratio of 1:1 (Officer and Ryther, 1980; Turner et al., 1998). The overall result is increased primary production (e.g., Turner and Rabalais, 1994; Lohrenz et al., 1997; Cloern, 2001; Rabalais, 2004), flux of a higher proportion of the organic carbon to the bottom, and subsequent bottom-water hypoxia (where the physical structure necessary is present).

Marine sources provide more nutrients than from the land in some coastal ecosystems, such as the East China Sea (Chen and Wang, 1999), by various physical processes, such as coastal upwelling and slope water intrusion (Liu et al., 2010). The estimated marine dissolved inorganic nitrogen and dissolved inorganic phosphorus fluxes to continental margins globally are larger than the total riverine loads by a factor of six to nine for nitrogen and by two to three for phosphorus (Walsh, 1991; Liu et al., 2008), but land-derived nutrients are projected to increase by a factor of 2.4 to 2.7 by the year 2050 in response to a growing human population (Tilman et al., 2001). Like the riverine nutrient loads, 
the oceanic nutrient supply is subject to alteration due to changes in circulation from GCC (e.g., Vecchi and Soden, 2007). Depending on the coastal environment, the residence time of river-supplied fresh water and rates of nutrient uptake and regeneration, the changes observed in the Anthropocene (Meybeck, 2003) from increased nutrient loads are most likely to lead to expansion of eutrophication and associated hypoxia. This does not preclude the potential for climate driven changes in oceanic nutrient sources from exacerbating an already precarious situation, as might be the case for the Oregon coast.

Oxygen is consumed in both the water column and the sediments. The relative contributions of water column and benthic respiration in the development of hypoxic vary. In the northern Gulf of Mexico severe bottom water oxygen depletion in mid-summer 2001 was due predominantly to benthic respiration (73\%) (Quiñones-Rivera et al., 2007). High contributions of benthic respiration (52 to 77\%) in association with bottom-water hypoxia have been observed in eutrophic Lake Erie during summer stratification (Ostrom et al., 2005). Subsequent work by Quiñones-Rivera et al. (2010) indicated that the relative proportion of water column and benthic respiration varied with year and season. Seasonal oxygen dynamics in surface waters were explained in a regression model by the concentration of algal biomass (as indicated by particulate organic carbon and $\mathrm{C} / \mathrm{N}$ ratio), while physical factors, such as salinity, temperature, water column stability and station depth were only of minor importance. Seasonal oxygen dynamics were more pronounced in bottom waters than in surface waters. Despite considerable overlap in oxygen saturation values, the relative contributions of benthic respiration in bottom waters during summer season $(75 \%)$ were noticeably higher and more variable compared to the winter season (42\%) (Quiñones-Rivera et al., 2010). The physical mixing of the water column caused by Hurricane Claudette prior to mid-summer mapping of the 2003 Gulf of Mexico hypoxic zone diminished the relative importance of benthic respiration, so that the system resembled typical wintertime conditions. Similarly in Lake Erie, benthic respiration became more important as summer progressed (Wang et al., 2008), increasing from $33 \%$ in early summer to $53 \%$ in late summer. In the Hong Kong Shing-Mun River temperature was the factor that increased the importance of benthic respiration leading to oxygen deficits (Chen et al., 2000).

\subsection{Sedimentary processes}

The excess organic material in the form of senescent phytoplankton, fecal pellets, and marine aggregates sinks to the lower water column and the seabed where the carbon is remineralized by aerobic and anaerobic processes or buried. As aerobic bacteria decompose the organic matter, the dissolved oxygen concentration overlying the sediments becomes hypoxic/anoxic. In this transition from oxic to suboxic to anoxic conditions, numerous biological and geo- chemical shifts occur. In the benthic community, bioturbation declines and mortality increases, which negatively impacts elemental cycling and creates feedback loops that exacerbate the cycle of eutrophication and declining oxygen levels (see Middleburg and Levin, 2009). In the Baltic Sea interannual changes in dissolved inorganic phosphate (DIP) pools in the Baltic proper were positively correlated to changes in sediment area covered by hypoxic water (Conley et al., 2002a). The changes in DIP were attributed to the release of $\mathrm{P}$ bound to feoxyhydroxides as dissolved oxygen concentrations transitioned to hypoxic conditions with $\mathrm{P}$ returning to the sediments during non-hypoxic conditions. With decreasing oxygen concentration, there is an increase in the flux of inorganic phosphorus from the sediments to the overlying water column (e.g. for Gulf of Mexico in Fig. 8) The rate at which excess phosphorus from hypoxic and anoxic waters re-enters the upper water column to further stimulate primary production and subsequent flux of additional organic matter is not known.

With continued accumulation of organic carbon at the seabed, microbial biomass and microbial decomposition potential of substrates and community oxygen consumption increase, but not in simple linear relationships (Meyer-Reil and Köster, 2000). The redox potential discontinuity layer migrates upward to the sediment-water interface, sulfate respiration replaces oxygen respiration, hydrogen sulfide is generated from the sediments and oxygen penetrates less deeply into the sediments as the bioturbation potential of the macroinfauna decreases during their demise due to sulfide toxicity or lack of sufficient oxygen (Gutiérrez et al., 2000). The sediments become less cohesive, more susceptible to resuspension and contribute to turbidity of the overlying water, which in turn reduces the potential for growth of the photosynthetic microphytobenthic community and generation of oxygen into the lower water column. Some shifts in the benthic microbial community are visible at the sediment-water interface (Jørgensen, 1980; Harper et al., 1981; Rosenberg and Díaz, 1993; Rumohr et al., 1996). Typical black spots from iron sulfide precipitated from intense microbial degradation of organic matter, lacey white colonies and denser, yellowish colonies of sulfur-oxidizing bacteria (Beggiatoa and Thiovulum), and reddish to violet carpets of sulfur-purple bacteria can also develop. These bacterial mats are indicators of suboxic condition and are commonly observed in both eutrophication driven hypoxia and where OMZs intersect the seabed (Graco et al., 2001; Levin et al., 2009a).

When the bottom water is depleted of oxygen, or anoxic, hydrogen sulfide builds up in the bottom waters as anaerobic bacteria metabolism reduces sulfate to $\mathrm{H}_{2} \mathrm{~S}$ (Jørgensen, 1980), the sediment becomes almost uniformly black, and there are no signs of aerobic life. Hydrogen sulfide is toxic to most metazoans and contributes to the overall benthic infaunal mortality.

The nitrification/denitrification cycle of estuarine and continental shelf sediments, which returns $\mathrm{N}_{2}$ to the atmosphere 

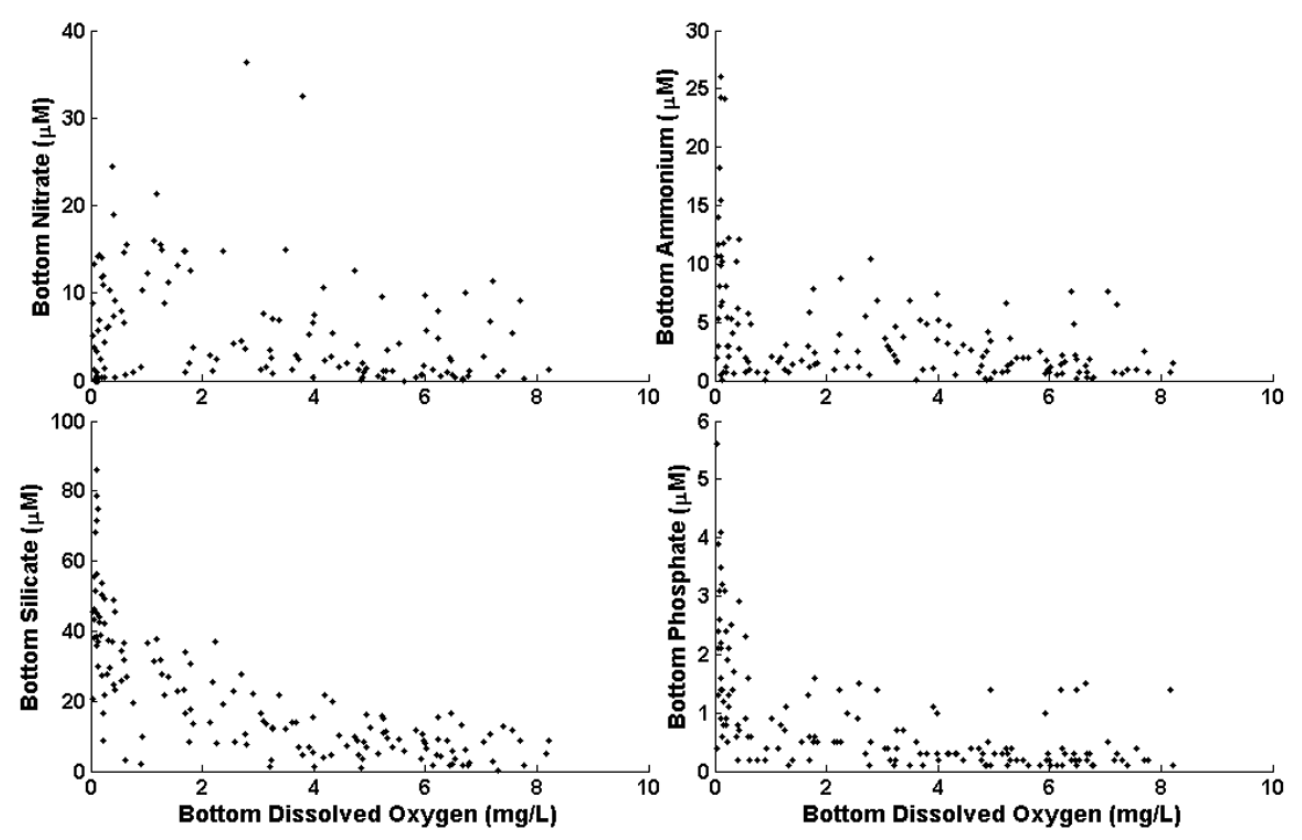

Fig. 8. Comparison of bottom water dissolved oxygen concentration and bottom-water dissolved inorganic nutrient concentrations for stations within the hypoxic area of the northern Gulf of Mexico (see Fig. 10), unpubl. data N. N. Rabalais and R. E. Turner.

is an ameliorating mechanism to excess $\mathrm{Nr}$, but is disrupted by the limited availability of oxygen in sediments. Denitrification proceeds much of the year but is dependent on the nitrate supplied by nitrification, a process that is dependent on the presence of oxygen, which for extended periods and over broad areas of the seabed may be absent (Kemp et al., 1990; Childs et al., 2002). With the shift in redox potential in the sediments with decreasing oxygen concentration, there is an increase in the flux of inorganic nutrients, ammonium, silicate, and particularly phosphate, into the overlying water (Fig. 8). These inorganic nutrients become available to fuel further phytoplankton production in the overlying water. The degree to which these nutrients diffuse upward through the water column and across strong pycnoclines is not known. High waves or strong currents will likely break down the physical structure of the water column, re-aerate the water column and resuspend sediments and adsorbed and dissolved nutrients into shallow to intermediate depth water column with a subsequent stimulatory effect for primary production (Dagg, 1998). These events, however, are short-lived and may occur during seasons when restratification is unlikely to occur and subsequent accumulation of phytoplankton biomass may be limited, i.e., a short-term stimulation of phytoplankton response but not a long-term accumulation of plankton-derived organic matter that would lead to further negative feedbacks on the system.

\subsection{The Baltic Sea and Scandinavian waters}

The Baltic Sea contains the largest anthropogenic hypoxic zone in the world (Díaz and Rosenberg, 2008). The combined hypoxic areas of the Baltic Sea (defined as $2 \mathrm{ml} \mathrm{L}^{-1}$ or $2.8 \mathrm{mg} \mathrm{L}^{-1}$ ) averaged $49000 \mathrm{~km}^{2}$ from 1961 to 2000 (Conley et al., 2009a). Hypoxic areas rim the Baltic Sea where increased nutrient loads have led to eutrophication and decreased dissolved oxygen concentrations. The Baltic Sea, a brackish ecosystem, is isolated from the North Sea by a series of shallow sills in the Danish Straits, and inflows of higher salinity oxygenated waters are limited but do improve the oxygen conditions (Gerlach, 1994). In the eastern and northern parts of the Baltic Sea the surface salinity is low, but increases towards the Danish Straits. A strong halocline separates the brackish surface water from the saltier bottom water. Few major oceanic inflows have taken place since the mid-1970s (HELCOM, 2007), resulting in areas of hypoxia in the lower water column between $12000 \mathrm{~km}^{2}$ in 1993 when inflows were at a minimum and $70000 \mathrm{~km}^{2}$ in 1971 the year after a large inflow, or 5 to $27 \%$ of the total bottom area (Fig. 9) (Conley et al., 2002a, 2009a).

Although hypoxia has occurred in the Baltic Sea during previous climatic warm periods (Zillén et al., 2008), nutrientdriven eutrophication is believed to be the primary cause of increases in hypoxia over the last 50 to $100 \mathrm{yr}$ (Conley et al., 2009b). Nitrogen and phosphorus concentrations in the bottom waters of the Baltic Sea tripled from 1960 to 1990. The hypoxia and anoxia in the deep basins of the Baltic Sea enhance phosphorus release from the sediments and increase 

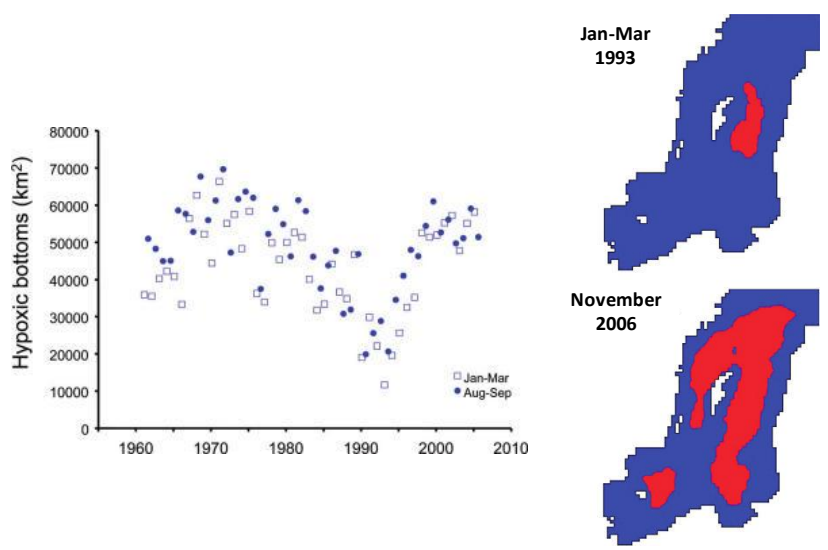

Fig. 9. Seasonal and interannual variations of the bottom area covered by hypoxic waters containing less than $2 \mathrm{ml} \mathrm{L}^{-1}$ oxygen (left panel). Oxygen fields were averaged over August-September (filled circles) and January-March (open squares) for each calendar year for the Baltic Proper, which includes the Gulf of Finland and the Gulf of Riga. Spatial distributions (right panels) for hypoxic waters containing less than $2 \mathrm{ml} \mathrm{L}^{-1}$ during its minimum area in 1993 covering $11050 \mathrm{~km}^{2}$ of bottom and in 2006 covering $67700 \mathrm{~km}^{2}$ of bottom (from Conley et al., 2009a).

nitrogen loss (Conley et al., 2002a). Eutrophication of the Baltic Sea in the last quarter of the 20th century has led to a large increase in the macrofauna biomass in shallow well-oxygenated bottoms relative to the first quarter of the 20th century, while deeper hypoxic and anoxic bottoms are now devoid of macrofauna (Elmgren, 1989; Karlson et al., 2002). Coastal areas within the Baltic that are hypoxic have increased over the last several decades (Díaz and Rosenberg, 2008).

The amount of dissolved inorganic phosphate released from sediments during hypoxia is approximately one order of magnitude greater than the anthropogenic total phosphorus loading (Conley et al., 2002a), and increases with decreasing dissolved oxygen concentrations. Removal of nitrogen through denitrification increases in the Baltic Sea as oxygen deficiency become more severe. The high phosphorus and low nitrogen concentrations are favorable for blooms of $\mathrm{N}_{2}$ fixing cyanobacteria, thus increasing the available nutrients and leading to more eutrophication (Vahtera et al., 2007) and more hypoxia.

Danish marine waters display all the classic symptoms associated with eutrophication, including periods of hypoxia and anoxia in bottom waters (Conley and Josefson, 2001; Conley et al., 2002a, b) and the mortality of benthic-dwelling organisms during anoxia (Fallesen et al., 2000; Conley et al., 2002b). Hypoxia is widespread in areas of the Skagerrak and Kattegat, the coastal waters of the North Sea, and many coastal embayments and fjords. Nutrient loading from Denmark ranks among the highest in Europe per unit area (Conley et al., 2002b) and reflects the density of the population and the intensity of the agriculture and animal production.

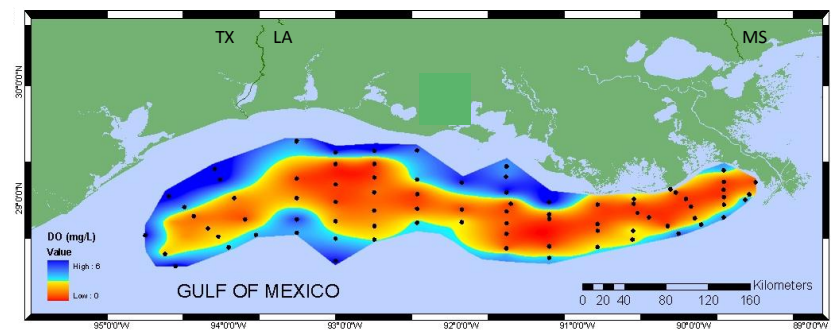

Fig. 10. Gulf of Mexico bottom-water hypoxia in mid-summer, 2127 July, 2008. Delineation between yellow and turquoise indicates dissolved oxygen less than $2 \mathrm{mg} \mathrm{L}^{-1}$ Dots indicate stations. Data source: N. N. Rabalais and R. E. Turner. Funding source: NOAA, Center for Sponsored Coastal Ocean Research.

\subsection{Mississippi River-influenced Gulf of Mexico}

The Mississippi River watershed at $3.27 \times 10^{6} \mathrm{~km}^{2}$, encompasses $41 \%$ of the lower 48 United States, and includes 31 states and numerous regulatory authorities, both state and federal. The Mississippi River system ranks among the world's top ten rivers in watershed size (third), freshwater discharge (seventh) and sediment delivery (seventh) (Milliman and Meade, 1983). Thus, the dimensions of the problem and the drainage system that affect it reflect a much greater magnitude than most nutrient driven eutrophication problems elsewhere. The hypoxic zone on the continental shelf of the northern Gulf of Mexico is the second largest human-caused hypoxic zone in the coastal ocean (Rabalais et al., 2007a). The Mississippi River creates a strongly stratified coastal system west of the delta for much of the year and delivers two to three times more nutrients now than in the 1950s. The area of bottom covered by hypoxic water can reach $22000 \mathrm{~km}^{2}$ and averaged $13500 \mathrm{~km}^{2}$ between 1985 and 2009 (updated from Rabalais et al., 2007a). The hypoxia occurs from February through November and is nearly continuous from mid-May through mid-September (Fig. 10 depicts widespread hypoxia in July 2008).

In mid-summer, the size of the hypoxic zone is most closely related to the nitrate load of the Mississippi River in the two months prior to the mapping $y\left(\mathrm{~km}^{2}\right)=-1337953.4+(672.1589 \cdot$ Year $)+(0.998$. May flux as $\mathrm{NO}_{3}^{-2}$ ); Turner et al., 2006, and the same size hypoxic area is now formed with a lower nitrate load than historically (Turner et al., 2008; Greene et al., 2009).

Changes in the nitrate loads over time are due mostly to the change in nitrate concentration in the Mississippi River $(80 \%)$ and the remainder is due to increased freshwater discharge (20\%) (Donner et al., 2002; Justić et al., 2002). More precisely, the US Geological Survey has identified specific activities for sources of nitrogen and phosphorus yields from the Mississippi River watershed and locations (Fig. 11) (Alexander et al., 2008). Most of the excess nutrients from the basin come from extensive corn and soybean row crops 
Table 1. Changes in water discharge and nitrogen flux from the Changjiang over three time periods.

\begin{tabular}{lcccl}
\hline Period & $\begin{array}{c}\text { Fresh Water } \\
\text { Discharge } \\
\left(\times 10^{9} \mathrm{~m}^{3} \mathrm{yr}^{-1}\right)\end{array}$ & $\begin{array}{c}\text { Nitrate } \\
\text { Concentration } \\
(\mu \mathrm{M})\end{array}$ & $\begin{array}{c}\text { Nitrogen } \\
\text { Flux } \\
\left(\times 10^{9} \mathrm{Mol} \mathrm{yr}^{-1}\right)\end{array}$ & References \\
\hline $1960 \mathrm{~s}$ & 898.9 & $30-40$ & $27-36$ & Gu et al., 1981a, b \\
$1980 \mathrm{~s}$ & 889.7 & 63.4 & 56.4 & Zhang et al., 1999 \\
$2001-2005$ & 887.7 & 81.3 & 72.2 & J. Zhang, Unpublished data \\
\hline
\end{tabular}

in tile-drained fields, which are the recommended sources for reductions to mitigate Gulf of Mexico hypoxia (Fig. 11) (Alexander et al., 2008; USEPA, 2009).

Evidence from paleoindicators (reviewed by Rabalais et al., 2007b) and models that relate the size and frequency of the hypoxic zone to nitrate-N load of the Mississippi River (Justić et al., 2002; Scavia et al., 2003; Turner et al., 2006) converge on the period of the early 1970s as to when hypoxia as a large scale phenomenon began. Community changes in hypoxia-intolerant benthic foraminiferans began early in the 1900s with landscape alterations (Rabalais et al., 1996, 2007b), but most shifts in eutrophication/hypoxia foraminiferan indicators began in the mid-1950s consistent with increases in sediment total organic carbon, biogenic silica remains of diatoms, nitrate-N loads from the Mississippi River, and fertilizer use in the Mississippi River watershed (Sen Gupta et al., 1996; Ostermann et al., 2009).

A proxy for labile organic matter in the sediments is the biogenic silica (\%BSi) content of sediments. Some carbon undergoes diagenesis after burial, whereas diatoms preserve well, so the \%BSi is a better proxy for the original organic material accumulating in the sediment surface than is the organic carbon itself. The \%BSi in dated sediments collected within the hypoxic zone has risen since the 1970s as the hypoxic area expanded, whereas it did not rise in the area outside the hypoxic zone (Turner and Rabalais, 1994). The $\% \mathrm{BSi}$ rose above the normalized value of 0.8 in the $1970 \mathrm{~s}$, which is when the first significant amount of hypoxic water formation in summer was estimated to have started (Justic et al., 2002; Scavia et al., 2003). The \%BSi has continued to rise since then so that it was about five times higher by 2000 than in the 1970s (Turner et al., 2008). The relationship between the ratio of hypoxic area size to nitrate-N load in May and the biogenic silica content (\%BSi) of dated sediments in the hypoxic zone is significant with an $R^{2}$ value of $0.60(p<0.01)$. No other factor improved the model fit (i.e., monthly and annual loading of TP, river discharge, TN/TP ratios, and combinations of these values). The steep rise when the normalized \% BSi=1.0 indicated that a threshold had been exceeded. Eighty-one percent of the variation in the size of hypoxia over the 17 years with concurrent measurements (1981-1997) is described in a multiple regression equation using only the May nitrate+nitrite $\mathrm{N}$ loading (NN; $1000 \mathrm{mt}$ ) and the normalized value of the \%BSi in the sediments (adj. $\left.R^{2}=0.81 ; p=0.0001 ; \quad Y=-3661+(62.1 \cdot \mathrm{NN})+(3868 \cdot \% \mathrm{BSi})\right)$. The increasing amount of $\% \mathrm{BSi}$ in sediments is consistent with the hypothesis that the sediment oxygen demand rose over the last several decades. Turner et al. (2008) concluded that there has been a system-wide response to the combination of organic buildup in the sediments and higher nitrogen loading, which has increased the area of hypoxia generated for a given nitrogen load and has increased the opportunity for hypoxia to develop.

\subsection{East China Sea}

The Changjiang (Yangtze River) and East China Sea provide another example of the complex problems that arise with major changes in the watershed and result in dramatic impacts on the development of eutrophication in surface waters and hypoxia in near-bottom waters of the adjacent shelf region. The historical water discharge of the Changjiang is $928 \times 10^{9} \mathrm{~m}^{3} \mathrm{yr}^{-1}$ and accounts for 90$95 \%$ (ca. $1 \times 10^{12} \mathrm{~m}^{3} \mathrm{yr}^{-1}$ ) of the freshwater input to the East China Sea. Other large rivers contributing fresh water are the Qiantangjiang $\left(40 \times 10^{9} \mathrm{~m}^{3} \mathrm{yr}^{-1}\right)$, Minjiang $\left(54 \times 10^{9} \mathrm{~m}^{3} \mathrm{yr}^{-1}\right)$, and Jiulongjiang $\left(14 \times 10^{9} \mathrm{~m}^{3} \mathrm{yr}^{-1}\right)$. Through human intervention over the watersheds of the Changjiang (e.g., hydraulic engineering and change in land use), there has been a step-wise reduction of sediment input to the East China Sea (Qu et al., 2005; Yang et al., 2006) as dams are built and water is extracted. Despite the capturing or removing of water, however, an increase in humansourced nitrogen and phosphorus influx from the Changjiang since the 1960s has been reported (Zhang, 1994; Liu et al., 2003). For instance, the Changjiang discharged approximately $30 \mathrm{Gmol} \mathrm{N} \mathrm{yr}^{-1}$ to the East China Sea in the $1960 \mathrm{~s}$ and more recently $72.2 \mathrm{Gmol} \mathrm{N} \mathrm{yr}^{-1}$ at beginning of the $21 \mathrm{st}$ century, or a $260 \%$ increase (Table 1). Over the same period, the N/P ratio increased from $30-40$ to ca. 100. This increase in nitrogen flux sustains the high productivity of the shelf.

In the region of 20-75 m water depth off the Changjiang, near-bottom hypoxia has been observed with dissolved oxygen concentrations as low as $1-2 \mathrm{mg} \mathrm{L}^{-1}$ (Tong and Zhang, 2007; Wei et al., 2007). The hypoxia on the inner shelf is usually found in summer and sometimes in early autumn 


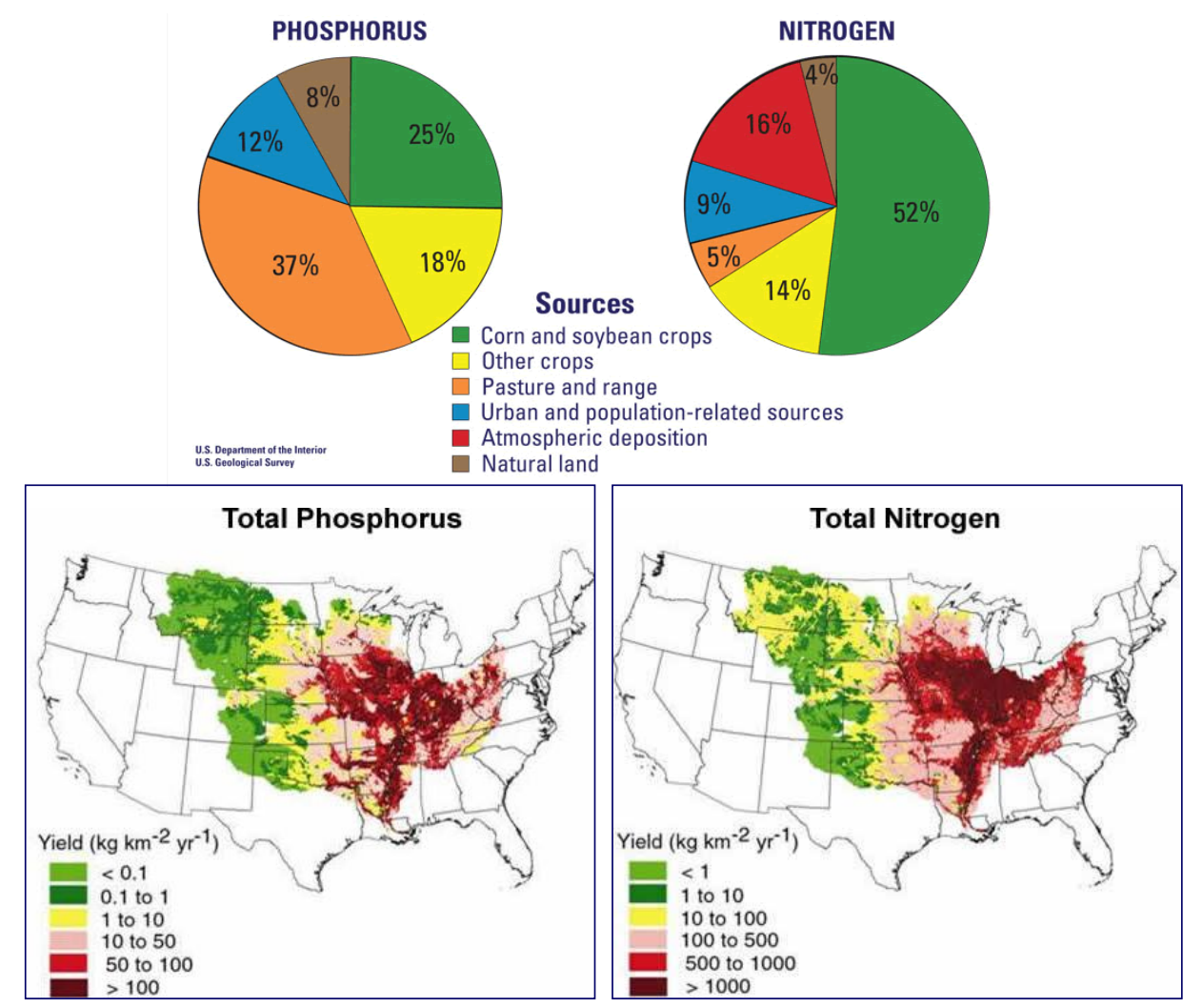

Fig. 11. Relative contribution of nitrogen and phosphorus sources based on land-use and activity (upper panel) and distribution of nitrogen and phosphorus yields throughout the Mississippi River basin (from http://water.usgs.gov/nawqa/sparrow/gulffindings/) and Alexander et al. (2008).

(i.e., July-September). The hypoxic area increased from ca. $1800 \mathrm{~km}^{2}$ in August, 1959 to $>15400 \mathrm{~km}^{2}$ in August, 2006 (Chen et al., 2007; Zhu, 2007). The temporal distribution and configuration of hypoxia on the shelf is driven by the dynamic circulation in the East China Sea. The core area, where hypoxia is most concentrated, changed from year-toyear, but generally was observed in 40- to 50-m water depths from $29^{\circ} \mathrm{N}$ to $33^{\circ} \mathrm{N}$. Sometimes, two hypoxic core areas were identified.

\subsection{Northern Adriatic Sea}

Historical data from the northern Adriatic Sea, going back to 1911, show increasing oxygen concentrations in the surface water and decreasing oxygen concentrations in the bottom water as well as decreasing water clarity associated with an increase in phytoplankton biomass. These trends are consistent with increasing nutrient loads in the Po River and development of hypoxia in the northern Adriatic Sea (Fig. 12) (Justić et al., 1987; Justić, 1988, 1991b). The loss of taxa of pelagic medusae, which depend on benthic stages as part of their life cycle, is also consistent with the expanding hypoxia (Benović et al., 1987). Paleoindicators in sediment cores from the vicinity of the Po River delta plume indicate a grad- ual increase in eutrophication at the end of the 19th century, which accelerated after 1930. Prior to the 19th century there are aperiodic accounts of massive phytoplankton blooms that likely led to oxygen depletion (Crema et al., 1991). Seasonal hypoxia began in 1960 and became more intense and prolonged in 1980 (Barmawidjaja et al., 1995). The area of hypoxia ranged from $250 \mathrm{~km}^{2}$ in 1974 to $4000 \mathrm{~km}^{2}$ in 1989 , but it was not always in the same location. Over the years virtually no part of the northern Adriatic Sea was unaffected by hypoxia (Riedel et al., 2008). From the early 1980s, mass mortality of bottom fauna has been a common occurrence (Stachowitsch, 1984, 1991, unpubl. data).

\subsection{Chesapeake Bay}

Eutrophication and, especially, hypoxia and anoxia are welldocumented and recognized as an environmental problem in the Chesapeake Bay, USA (Kemp et al., 2005, 2009). Chesapeake Bay is the largest estuary in the United States and one of the largest in the world with tidal waters extending over $11400 \mathrm{~km}^{2}$ and a drainage basin covering $1.7 \times 10^{5} \mathrm{~km}^{2}$. The Susquehanna River, the largest tributary to the bay, drains $71200 \mathrm{~km}^{2}$, accounting for $41 \%$ of the Chesapeake Bay watershed and $80 \%$ of the area draining directly into the bay. 


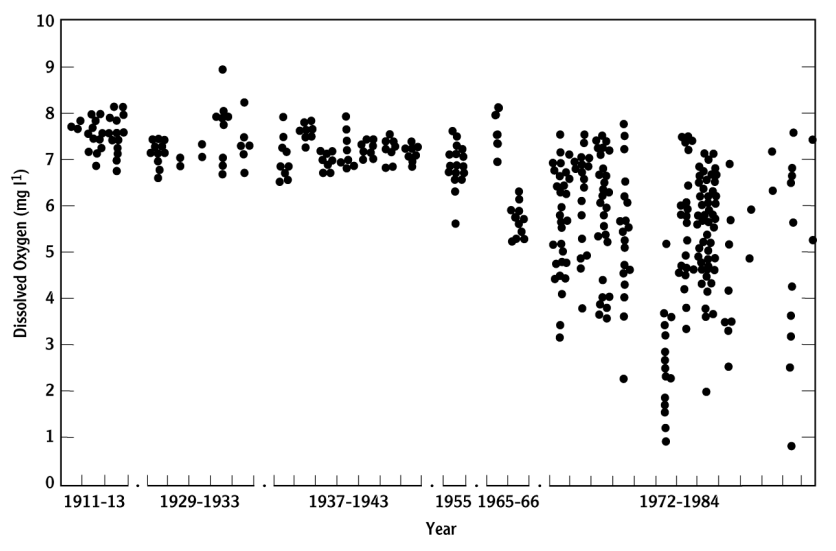

Fig. 12. Oxygen content $2 \mathrm{~m}$ above the bottom during AugustSeptember in the northern Adriatic Sea from 1911 to 1984 for the periods indicated. Surface water oxygen content increased in the 1972-1984 summer period, and Secchi disk depth during AprilMay decreased dramatically in 1966 and in the 1972-1984 period. Statistical trends for the bottom water oxygen (shown), surface water oxygen and Secchi disk depth were all significant at $P=0.05$. Redrawn from Justić (1991) with permission.

The bay is relatively shallow (mean depth $6 \mathrm{~m}$ ), and the area of its catchment is large in comparison to the estuarine volume. This, coupled with its modest tidal exchange, makes the bay susceptible to stratification from fresh water and inputs of sediments and dissolved materials from the land (Horton, 2003; Hagy et al., 2004).

The Chesapeake Bay ecosystem has undergone substantial human-induced changes since colonization by Europeans almost 400 yr ago, including increased sedimentation resulting from clearing of its previously forested watershed (Brush, 1984, 2009; Cooper and Brush, 1991). During the period of agricultural expansion extending into the early 19th century, more plant nutrients - forms of nitrogen and phosphorus that the native forests efficiently retained - also began to wash down into the Bay. Although there were numerous and cumulative, human-induced changes in Chesapeake Bay through the early 20th century, during the last half of the 20th century even more dramatic changes occurred from a growing population, runoff of agricultural fertilizers and animal wastes, and atmospheric deposition of nitrogen oxides from fossil fuel combustion and volatilization of ammonium from fertilizers and animal wastes. By the mid-1980s Chesapeake Bay was receiving about seven times more nitrogen and 16 times more phosphorus than when English colonists arrived (Boynton et al., 1995). The result of these increased nutrient loads and multiple stressors, such as overharvesting of fisheries resources, was high concentrations of phytoplankton biomass, reduced water clarity, loss of submerged aquatic vegetation, loss of shellfish and fisheries production, and an increase in stressful low-oxygen conditions during the summer (Hagy et al., 2004; Kemp et al., 2005, 2009).

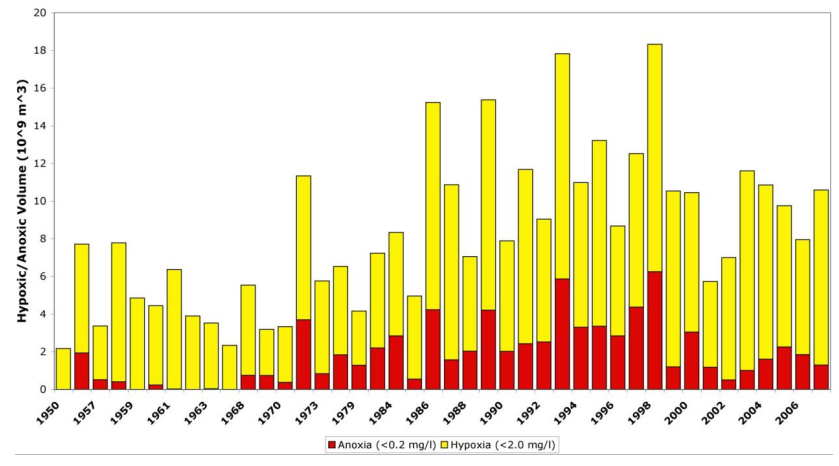

Fig. 13. Volume of hypoxic water in Chesapeake Bay (data from Hagy et al., 2004 and http://www.eco-check.org/forecast/ chesapeake/2009/indicators/hypoxia/).

Hagy et al. (2004) examined a 52-yr record of dissolved oxygen in Chesapeake Bay (1950-2001) and a record of nitrate-N loading from the Susquehanna River spanning a longer period $(1903,1945-2001)$ to describe the long-term pattern of hypoxia and anoxia in Chesapeake Bay and its relationship to nitrate-N loading. Year-to-year variability in river flow accounted for some of the observed changes in hypoxic volume, but the long-term increase was not due to increased river flow. From 1950-1985, the volume of hypoxic water in mid-summer averaged about $4.5 \mathrm{~km}^{3}$. After 1985 , the hypoxic volume increased substantially and averaged over $8 \mathrm{~km}^{3}$ from 1986 to 2007 (Fig. 13). Nitrate-N concentrations in the Susquehanna River at Harrisburg, Pennsylvania, increased up to three-fold from 1945 to a 1989 maximum and declined through 2001. On a decadal average basis, the combination of changes in river flow on the longterm and increase in nitrate- $\mathrm{N}$ resulted in a two-fold increase in nitrate-N loading from the Susquehanna River during the 1960 s to 1970 s. Decadal average loads were subsequently stable through the 1990s. Hypoxia was positively correlated with nitrate- $\mathrm{N}$, but more extensive hypoxia was observed in recent years than would be expected from the observed relationship (Hagy et al., 2004). This suggests that other factors may influence the amount of hypoxia in Chesapeake Bay. Over the years, the bay may have become more susceptible to nitrate-N loading similar to the situation observed for the Mississippi River-influenced northern Gulf of Mexico hypoxic zone (Turner et al., 2008; Greene et al., 2009; Kemp et al., 2009). Or, variation in climate, wind direction and intensity, may be modulating the extent and severity of hypoxia (Scully et al., 2005; Scully, 2009).

Although heavy fishing pressure and other stressors in Chesapeake Bay make it difficult to isolate the effects of eutrophication-driven hypoxia on fish (Breitburg et al., 2009), an increased ratio of pelagic to demersal fish species documented for the Chesapeake Bay (Kemp et al., 2005) is indicative of increased eutrophication. The shift from demersal-dominated to pelagic-dominated fisheries has been 
observed for other coastal systems and is attributed, in part, to bottom-water hypoxia (Caddy, 1993). It is not clear how hypoxia influences the habitat requirements of particular fish and invertebrates, but some species, such as sturgeons, cannot reproduce in Chesapeake Bay due to a lack of habitat with adequate oxygen and temperature levels (Secor and Gunderson, 1998). Habitat for Chesapeake Bay striped bass, which prefers cooler, deep waters, is also severely curtailed during summer months due to a combination of bottom water hypoxia and temperature (Coutant and Benson, 1990). During summer, striped bass adults selected narrow lenses within the water column characterized by $<25^{\circ} \mathrm{C}$ water and normoxia (Cheek et al., 1985). Using bioenergetic models Brandt and Kirsch (1993) mapped habitat suitability for striped bass in Chesapeake Bay and predicted substantial habitat restrictions in summer, leading to negative or static growth during summer months (Secor and Niklitschek, 2001).

Whereas impacts to fisheries have been difficult to determine, the impacts of hypoxia on benthic animals have been well documented (Holland et al., 1987; Dauer et al., 1992). Loss of habitat and prey biomass as a result of hypoxia can have profound effects on ecosystem energetics and services (Díaz and Rosenberg, 2008). Estimates of biomass lost due to hypoxia are approximately 10000 megatons of carbon per year, or 5\% of the Chesapeake Bay's total secondary production. Under normoxic conditions, an estimated $60 \%$ of benthic energy would be passed up the food chain, thus the seasonal hypoxic conditions in the bay possibly result in a loss of 6000 megatons of carbon (Díaz and Rosenberg, 2008).

\section{Reversal, or not, of human-caused hypoxia}

Most often increases in nutrient loads to estuarine and coastal waters are the cause of eutrophication-associated hypoxia. In some cases the increase in carbon loading and accumulation result from allochthonous sources, such as organic waste from pulp mill factories (such as Idefjord, Sweden Rosenberg, 1980 or Perdido Bay, Florida, USA - Flemer et al., 1999), fish aquaculture (such as Loch Ailort, Scotland - Gillibrand et al., 1996), or seafood processing plants (such as Saldanha Bay, South Africa - Christie and Moldan, 1977). It seems simple enough to remove the excess carbon inputs or to reduce nutrient loads to reverse the associated hypoxia. The process of eutrophication, however, has occurred over long time periods during which basic characteristics of the aquatic ecosystem change, such as composition of the phytoplankton community, sequential demise of components of the benthic community, shifts in sedimentary structure and composition, and biogeochemical processes. Thus, it is not surprising that reductions in nutrients or allochthonous carbon do not immediately, if ever, return a large aquatic ecosystem to its "prior" state and, seldom, a pristine state (for ex- ample pre-agricultural condition of the Mississippi River or northwest Black Sea watersheds).

Part of the problem for restoration efforts is that eutrophication and subsequent development of hypoxia do not occur in a vacuum. Other components of the ecosystem have changed along with the development of hypoxia. Overfishing, habitat destruction, invasive species, aspects of GCC, continued release of stored nutrients from the sediments of the coastal ecosystem (Conley et al., 2002a; Oguz, 2005), and continued input of excess nutrients from land runoff (Bennett et al., 2001; Galloway et al., 2008) prevent a similar reversed trajectory as the one leading to hypoxia.

Often nutrient reductions focus on a single nutrient, e.g., nitrogen through improved agricultural practices or tertiary removal of nitrate-N or phosphorus through improved urban waste water treatment. This results in an imbalanced ratio of the nitrogen and phosphorus to each other, which can affect phytoplankton community composition. Reductions are often required in both phosphorus and nitrogen. While some reduction mechanisms, such as reduced fertilizer use, would apply to both phosphorus and nitrogen loadings, the mechanisms required to reduce nitrogen, primarily as dissolved nitrate- $\mathrm{N}$ in runoff or groundwater or dissolved orthophosphate in runoff differ from that of phosphorus control through prevention of soil erosion. The relative proportion of nitrogen to phosphorus and nitrogen and phosphorus to silicate are important in defining phytoplankton community composition, trophic structure, and determination of which phytoplankton species are likely to dominate and/or contribute to carbon flux to the lower water column and seabed. There have been improvements in oxygen depletion conditions in many smaller systems around the world, and other examples of diminished symptoms of eutrophication through reductions in nutrient loadings (Fig. 14).

\subsection{Northwestern shelf of the Black Sea}

A socio-ecological experiment that tested whether increased nutrients leading to hypoxia and worsening hypoxia could be reversed by a reduction in nutrients that alleviates hypoxia occurred on the northwestern Black Sea shelf. The Black Sea shelf adjacent to the Danube River experienced hypoxia historically, but anoxic events became more frequent and widespread in the 1970s and 1980s (Tolmazin, 1985; Zaitsev, 1992; Mee, 2001; Mee et al., 2005), reaching over areas of the seafloor up to $40000 \mathrm{~km}^{2}$ in depths of 8 to $40 \mathrm{~m}$. The deep central part of the Black Sea is a permanently anoxic basin, but the northwestern margin that receives the freshwater inflows of the Danube River and the smaller Dneiper and Dneister rivers to the north experienced a surge of increased nitrogen and phosphorus loads in the 1960s to 1970s, similar to many other coastal areas downstream of developed nations (Galloway and Cowling, 2002; Rabalais, 2004; Li and Dalar, 2004). Beginning in the 1960s under the communist system the republics of the Soviet Union in the Danube River 
watershed, land was intensively farmed with large-scale production of livestock and heavy applications of nitrogen and phosphorus fertilizers, industrialization was on the rise, and human population - the source of waste water - was on the rise. The hypoxia was first recorded in 1973 and was present in increasing size through 1990.

The conditions on the northwestern shelf of the Black Sea improved from 1990 to 2000 when nutrient loads from the Danube River decreased substantially because of economic decline following the dissolution of the Soviet Union. Within $5 \mathrm{yr}$ following the end of intensive farming, decreasing nutrient loads were followed by a decrease in the extent of bottom-water hypoxia (Mee, 2001) from 1991 on until it was essentially absent barring a relapse in the hot summer of 2001 (Mee, 2006). Not all parts of the ecosystem recovered so rapidly with mussel communities re-establishing by 2002, but planktonic communities not at 1960s composition. As the central and eastern economies recover, especially with membership in the European Union, cultural eutrophication may again intensify with the recurrence of hypoxia. Being a member of the European Union, however, will require conformance to water quality standards and regulations. In the Black Sea, surrounding governments, aided by the United Nations Global Environment Facility, have agreed to pursue an initiative to maintain nutrient levels of the mid-1990s; the process appears to be aiding recovery through pilot-scale projects to improve farming practices and waste water treatment (Mee, 2006).

\subsection{Tampa Bay}

The Tampa Bay estuary (Florida, USA) is often heralded as an example as a successful nutrient abatement program with restoration of seagrass beds and alleviation of hypoxia (National Research Council, 2000; Duarte et al., 2009; Waycott et al., 2009). In the 1960s Tampa Bay was experiencing reduced water clarity, loss of seagrass beds, reduction in landings of speckled sea trout and areas of hypoxia (Simon, 1974; Johansson and Lewis, 1992). The Tampa Bay National Estuary Program developed an environmental goal of restoring water clarity and therefore seagrass beds in the Tampa Bay estuary (TBEP, 2006). Phytoplankton production and biomass in Tampa Bay are strongly nitrogen limited, due in part to drainage from the phosphate-rich Bone Valley deposits located within the watershed (Johansson, 2005). As is often the case, control of one nutrient is often more feasible and cost effective than control of another or both.

Improvements in wastewater treatment facilities starting in 1980 resulted in a total nitrogen reduction from this source by $90 \%$. Coupled with improved stormwater treatment and reductions in atmospheric deposition from local electric utilities, annual external nitrogen loads to Tampa Bay since 2000 are estimated to be less than one-half that estimated for the 1970s (Greening and Janicki, 2006). Average annual chlorophyll $a$ concentrations and water quality targets have been

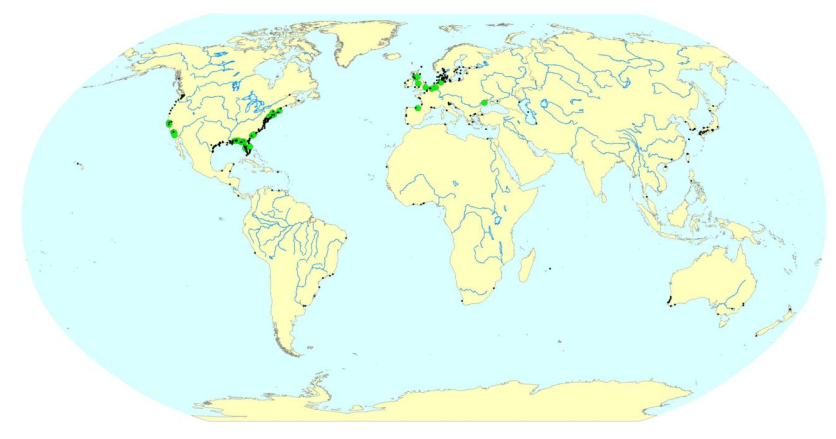

Fig. 14. Location of systems that have recovered from hypoxia (green circles), primarily through reduction of nutrient loads. All sites are in northern Europe and the United States, except the Black Sea. Black dots are systems that remain hypoxic.

met $85 \%$ of the time since 1995 (Sherwood, 2009). With increased water clarity, seagrass extent has expanded from 21 650 acres in 1982 to 29650 acres in 2008 (Robbins, 1997; SWFWMD, personal communication, 2009). Hypoxia still occurs in the deeper areas and dredged channels in summer months, but the spatial and temporal extent has been much reduced since 1980.

All seems a good success story. With the increase in the population of the Tampa Bay area (the second largest metropolitan area in Florida - TBEP, 2006), the Tampa Bay estuary is now experiencing additional loading from changes in land uses - from natural or low-intensity agriculture to residential. This nonpoint nutrient source is more difficult to control than point sources from wastewater and nitrogen point source controls.

\subsection{Chesapeake Bay}

In the 1970s the scientific community in the Chesapeake Bay area began to understand and document the pervasive changes in the ecosystem that had taken place and to identify their causes. This led to growing awareness by the public and political leaders, which in turn resulted in the evolution of regional management structures and restoration objectives (Hennessey, 1994; Boesch, 2002). A simple agreement among three states, the national capital district and the federal government in 1983 "to assess and oversee the implementation of coordinated plans to improve and protect the water quality and living resources of the Chesapeake Bay estuarine systems", led to the Chesapeake Bay Program. A series of directives and agreements proposed reductions of nutrient and toxicant loads, habitat restoration, living resource management and landscape management. Reduction of hypoxia and anoxia was seen as the corner stone of the restoration effort with specific oxygen criteria developed to be protective of the fauna (Batiuk et al., 2009).

A landmark agreement of the Chesapeake Bay Program was the 1987 commitment to reduce controllable inputs of 
nitrogen and phosphorus entering the bay by $40 \%$ by the year 2000. As that year approached it was clear that this goal would not be reached and, furthermore, a complex array of interrelated issues of environmental quality, living resources, and human activities needed to be addressed in a more comprehensive manner. The Chesapeake 2000 Agreement was reached, which included over one hundred goals and commitments that together comprise one of the most ambitious ecosystem management programs for a large coastal area.

Progress in restoring the Chesapeake Bay ecosystem has been mixed (Boesch, 2006). Although eutrophication is no longer growing, there is a public debate concerning the amount of nutrient load reductions that have been achieved, and few clear signs that the symptoms have been alleviated, except locally. The concentrations of a number of potentially toxic substances in sediments and organisms declined. Seagrasses have returned in some regions but cover only a small portion of the habitat occupied in the 1950s. Oyster populations have not recovered. Populations of several anadromous fishes have increased modestly. Populations of striped bass have increased. On the other hand, the productive blue crab fishery has shown some decline in recruitment and signs of over-fishing. Small improvements in dissolved oxygen conditions are expected for the mainstem of the Chesapeake Bay, and the outlook for rivers draining into the Bay ranges from slight deterioration to slight improvement (Bricker et al., 2007; Kemp et al., 2009).

\subsection{Baltic Sea}

Since the late 1980s, the Convention on the Protection of the Marine Environment of the Baltic Sea (Helsinki Commission - HELCOM) has worked to implement a $50 \%$ reduction target for anthropogenic nutrient loads. In 2007, HELCOM reached an international agreement to reduce the effects of eutrophication, with targeted nutrient reductions for each country (HELCOM, 2007). By reducing specific point sources, such as industrial and municipal wastewater, there has been some local improvement in eutrophication and associated hypoxia. However, the reductions needed are far from reaching the targeted goals. The immense size and volume of the Baltic Sea hypoxia and the negative feedbacks to the nutrient cycles from the anoxic bottom layer will hamper remediation of hypoxia unless there are substantial, long-term efforts to reduce nutrient loads (Conley et al., 2009a).

Because of the immensity of the hypoxia problem in the Baltic Sea, the Swedish Environmental Protection Agency, other national agencies, and engineering concerns are examining ways to oxygenate the bottom layers or to increase the precipitation and sequestration of phosphorus, resulting in less release from the sediments (Vahtera et al., 2007; Conley et al., 2009a). Large-scale engineering schemes include aeration by bubbling oxygen into the bottom hypoxic layer and manipulation of currents so that there is increased flushing of the water into and out of the Baltic Sea and thus reduced resi- dence time. The volume needed and the technology involved are seemingly insurmountable obstacles to bringing in higher concentration dissolved oxygen. And, while there is a general understanding of nutrient biogeochemical cycles in the Baltic Sea and the effects of those on hypoxia (Conley et al., $2009 b$ ), the effects of remediation efforts on phosphorus, nitrogen and silica biogeochemical cycles raise concerns and require additional knowledge (Conley et al., 2009a). Chemical precipitation has been suggested as a method to remove phosphorus from the water column and enhance permanent phosphorus burial, but little is known about the effects of brackish water usage compared to freshwater lakes and the effects of precipitation of aluminum and silica with regard to toxicity and trophic interactions, respectively. Biomanipulations should be approached cautiously because of unintended, negative results on ecosystem health and function. Any solution to hypoxia in the Baltic Sea must include large reductions in the inputs of nutrients and consideration of balanced nutrient concentrations. Engineered, or otherwise manipulated, solutions may be beneficial on more local scales, but probably unfeasible in the Baltic Proper (Conley et al., 2009a).

\subsection{Mississippi River and northern Gulf of Mexico}

Social and political acceptance of the linkages between increased loads of Mississippi River nutrients and the expansion and worsening of hypoxia on the northern Gulf of Mexico continental shelf lags behind that of the Chesapeake Bay, Tampa Bay, and the Baltic Sea, and there is to date no identified target nutrient reduction embodied in an action plan. The evidence was easily ignored or "denied" at first, and continues, because of the distance from the area of most nitrogen and phosphorus sources, half a continent away, and a natural tendency for agri-business to protect their interests in this economically important region. Many studies and subsequent peer-reviewed publications continue to enhance the scientific understanding of changes in the watershed, landscape use, nutrient inputs, and linkages of increased nutrient loads and relative ratios on important biological processes of the Mississippi River-influenced shelf and increasing hypoxia.

The US Geological Survey has identified specific activities for sources of nitrogen and phosphorus yields from the Mississippi River watershed and their locations (Fig. 11; Alexander et al., 2008). Most of the excess nutrients from the watershed come from extensive corn and soybean row crops in tile-drained fields in the middle of the US, an area commonly known as the "Corn Belt". These sources were recommended for specific targeting and reduction for an overall decrease in both nitrogen and phosphorus loads by $45 \%$ of current levels to mitigate Gulf of Mexico hypoxia (US Environmental Protection Agency, 2008). A 2001 Action Plan (Mississippi River/Gulf of Mexico Watershed Nutrient Task Force, 2001), based on a thorough review of the available literature 
and data, was delivered to Congress and President Clinton in early January 2001. This plan proposed an environmental goal of reaching an areal size of hypoxia of $5000 \mathrm{~km}^{2}$, over a five-year running average by 2015 , with implementation through voluntary actions and incentives. The Plan floundered between 2001 and 2009 with no input of necessary funds to implement nutrient reductions or to monitor any responses. A subsequent review of old and new data and information was completed by the US Environmental Protection Agency (2008) that reinforced the science and the need for nutrient reductions of both nitrogen and phosphorus. The 2008 Gulf Hypoxia Action Plan (Mississippi River/Gulf of Mexico Watershed Nutrient Task Force, 2008), completed in parallel to the US EPA science assessment, is limping along without much support, as yet, from most federal agencies and the signatory states, with the exception of NOAA and more progressive states with regard to nutrient mitigation, such as Minnesota in the head waters.

The Mississippi River is seen as an "orphan" with regard to a united, coordinated effort to reduce nutrients (NRC, 2008). There is a lack of coordinated and consistent monitoring of nutrients and differing state approaches to assessing waters for the Clean Water Act Section 303(d) designations for meeting water quality standards. The lack of a suitable framework for making decisions, a less than adaptive 2008 Gulf Action Plan, a negative governmental response to the issue from 2001-2008, and lack of adequate funds for mitigation and monitoring stymie progress.

\subsection{Approaches and implications of nutrient reduction}

Nutrient control efforts are usually more successful in reducing point sources of nitrogen and phosphorus than with the multiple nonpoint sources of high solubility and growing atmospheric inputs of nitrogen. The success with point sources and the lack of success with nonpoint sources, may lead to critical imbalances of nitrogen to phosphorus, or silica to both, so that there is no decrease in phytoplankton biomass, but instead a shift to another species composition, potentially more noxious or toxic. On the other hand, a reduction in silica compared to nitrogen could result in silicalimited phytoplankton communities that may be less desirable to zooplankton grazers, affect the flux of organic matter to the seabed, or affect trophic interactions (Officer and Ryther, 1980; Tilman et al., 1982; Turner, 2001; Turner et al., 1998). Closer attention should be paid to the importance of balanced nutrient composition as well as nutrient supply dynamics for the development of eutrophication versus efficient trophic transfer and fish production in nutrient-enriched systems (Kristiansen and Hoell, 2002). In the process of nutrient management by reducing loads, consideration should also be given to all ecosystem services that are likely to be influenced by intervention (e.g., food, oxygen production through photosynthesis, primary production, nutrient cycling and habitat provisioning, Costanza et al., 1997; de Groot et al., 2002;
Millennium Ecosystem Assessment, 2005; Snelgrove et al., 2009).

There is concern that reductions in the high levels of nutrients that support high levels of primary production will lead to reductions in fisheries yields (Nixon, 2009). The fear of reducing fishery yields adjacent to the Mississippi River delta is sometimes raised as a reason not to reduce nutrient loads (Grimes, 2001). The waters adjacent to the Mississippi River delta have long been known as the Fertile Fisheries Crescent (Gunter, 1963), which emanates from the nutrient-enriched region in a bull's-eye pattern of sequentially reduced fisheries yields. But there are systems where drastic nutrient reductions have reduced fisheries. The closure of the Aswan High Dam on the Nile River in 1965 resulted in a reduction in freshwater discharge and sediment and nutrient loads to the Nile delta with a subsequent loss of coastal diatom blooms and the shrimp fishery the blooms supported (Nixon and Buckley, 2002). The reduction in shrimp landings lasted about 25 years, the time it took for increased use of agricultural fertilizer and waste water from dense human populations in the delta region to replace the natural fertility of the Nile River (Nixon, 2003, 2004; Oczkowskia et al., 2009). A comparison with the Nile River delta is not appropriate for the Mississippi River, because the increased nutrient load and associated bottom-water hypoxia in the northern Gulf of Mexico have turned the fertile bull's-eye pattern to altered distributions and abundances of demersal species, particularly the brown shrimp (Craig et al., 2005). It is feasible to maintain a high fisheries production with the same nutrient loads of the 1950s, given other factors holding constant, e.g., fishing pressure. Whether the Gulf of Mexico fisheries adjacent to the Mississippi River could return to the fertile fisheries crescent of the early 1950s depends on the form of the reversed trajectory of nutrient loads (quantity and ratios), nutrient concentrations, phytoplankton biomass, trophic interactions, and food webs (see Kemp et al., 2009).

The growing decline of coastal water quality and expansion of symptoms of eutrophication and also the proven successes of reducing nutrients, however, are reasons enough to continue and to expand efforts to reduce nutrient overenrichment. This is most important for systems that are currently eutrophic and have oxygen problems, where unusually warm and calm weather can tip the system from one with highly productive fisheries to one dominated by microbes. An example of weather exacerbated anoxia can be seen in the Mariager Fjord, Denmark. The 1997 summer in Denmark was unusually warm, sunny and calm. The high temperatures increased the rate of oxygen consumption, and the lack of wind mixing limited ventilation of deeper waters. As a result, the mussels at 8 to $10-\mathrm{m}$ water depth died and contributed to the oxygen depletion. Then, the mussels at shallower depths died and the anoxic and hydrogen sulfiderich zone gradually moved upward. After the massive phytoplankton bloom in the middle of August, the oxygen demand increased further due to the decomposition of phytoplankton. 


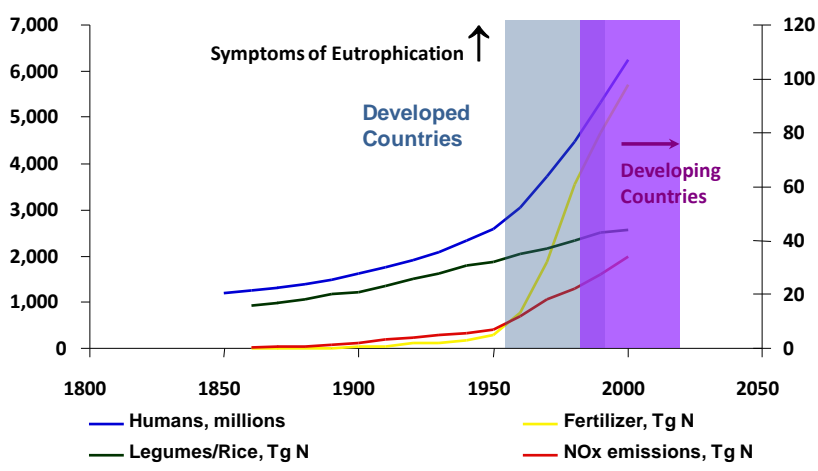

Fig. 15. Period in which the symptoms of eutrophication and hypoxia/anoxia began in developed countries and how the symptoms are shifted to more recent years for developing countries (modified by N. N. Rabalais from Galloway and Cowling, 2002; Boesch, 2002).

The long period of calm and unusual warm weather reducing the mixing in the surface was the triggering factor, but the geomorphology of the fjord and the high concentrations of nutrients mostly discharged from land were the basic drivers of the anoxia (Fallesen et al., 2000). To restore systems like this that are naturally prone to development of low oxygen, causal factors such as nutrient loadings need to be reduced beyond the level that will reduce hypoxia.

\section{Global change and future expectations}

\subsection{Increases in eutrophication-driven hypoxia}

The occurrence of hypoxia in coastal areas is increasing, and the trend is consistent with the increase in human activities that result in increased fluxes of nutrients to waters. More and more coastal systems, especially in areas of increased industrialization and mechanized farming, where the physical conditions are appropriate and where nutrient loads are predicted to increase, will likely become eutrophic with accompanying hypoxia (Fig. 15).

The continued and accelerated export of nitrogen and phosphorus to the world's coastal ocean is the trajectory to be expected unless societal intervention in the form of controls or changes in culture are pursued. The largest increases are predicted for southern and eastern Asia, associated with predicted large increases in population, increased fertilizer use to grow food to meet the dietary demands of that population and increased industrialization (Seitzinger et al., 2002). Increased production of biofuels in many countries will further amplify nutrient delivery from the land to the sea (National Research Council, 2008; Simpson et al., 2008).

The implications for coastal eutrophication and subsequent ecosystem changes such as worsening conditions of oxygen depletion are significant. Depending on the coastal environment, the residence time of river-supplied freshwater

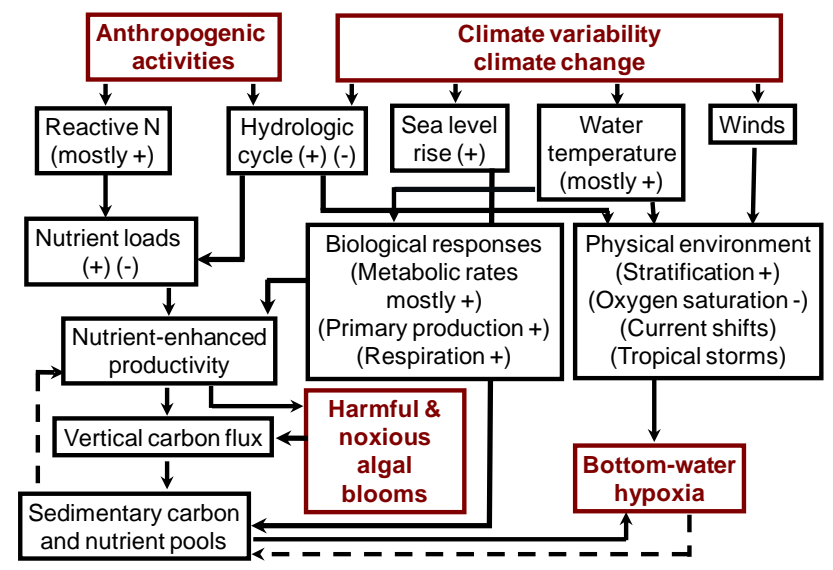

Fig. 16. Potential physical and hydrological changes resulting from climate change and their interaction with current and future human activities. The dashed lines represent negative feedback to the system (modified from Rabalais et al., 2009).

and rates of nutrient uptake and regeneration, the changes observed in the Anthropocene (Meybeck, 2003) from increased nutrient loads are most likely to lead to human-caused eutrophication and associated hypoxia. This does not preclude the potential for climate driven changes in oceanic nutrient sources from exacerbating an already precarious situation.

\subsection{Climate change and coastal waters}

The world's climate has changed and human activities will continue to contribute to the acceleration of greenhouse gases and temperature rise. The regional outcomes of the various GCC scenarios (IPCC, 2007) will be manifested in many different and synergistic effects on various components of ecosystems. These outcomes may be difficult to detect in the near-term, because they currently exist within the "background" variability inherent in natural systems, and also because there are effects from other human-caused changes. As in the sense of multiple stressors, it will be difficult to differentiate completely the GCC aspect and the anthropogenic activities aspect of global change on eutrophication and associated hypoxia (Fig. 16).

If the average global temperature rises $0.4^{\circ} \mathrm{C}$ over the next three decades and 1.8 to $4.0^{\circ} \mathrm{C}$ over the next century (IPCC, 2007), then there will be major changes in ecosystem structure and function. The major drivers of these changes are increased temperature, altered hydrological cycles and shifts in wind patterns that might alter coastal currents (Fig. 16) (Wolock and McCabe, 1999; Rabalais et al., 2009). Increasing temperatures alone have the potential to strengthen pycnoclines in estuarine and coastal waters, but lower surface salinity (e.g., from increased freshwater runoff) would be more of a factor in stratifying the water column. For example, at $20^{\circ} \mathrm{C}$ and $32 \mathrm{psu}$, a 1 psu decline in salinity changes seawater density by a factor of about 3 relative to a $1{ }^{\circ} \mathrm{C}$ 
increase in temperature (Fonfonoff and Millard, 1983). A stronger pycnocline (density differences dictated by a combination of temperature and salinity) may result in less diffusion of oxygen from the upper water column to the lower water column, leading to less dissolved oxygen in bottom waters.

Increased temperatures may also affect regional wind patterns and large-scale modes of climate such as the El Niño Southern Oscillation and the North Atlantic Oscillation, leading to changes in circulation and mixing (Johnson and Gruber, 2007). If wind patterns or intensity change, then coastal currents and their effects on coastal waters might change to either aggravate a low oxygen condition or to, in fact, alleviate it. An example of the increasing hypoxia can be found off the Oregon and Washington coasts, where wind-driven shifts in the California current system in 2001 and subsequent years altered the long-term pattern of upwelling and resulted in extensive hypoxia along the inner shelf (Grantham et al., 2004; Chan et al., 2008). In Chesapeake Bay, Scully (2009) found a correlation between the North Atlantic Oscillation, which affects the strength of westerly winds and stratification (Scully et al., 2005) and volume of hypoxia. On the other hand, shifts in coastal currents may bring cooler waters, albeit with higher nutrients onto shelf areas.

If the frequency of tropical storms and hurricanes increases as a result of increased water temperatures in the lower- to mid-latitudes as predicted in GCC, the vulnerability of coastal habitats will be greatly increased. Warmer Atlantic Ocean sea surface temperatures could increase the frequency and severity of tropical storms (Trenberth, 2005; Hoyos, 2006; Kerr, 2006; Mann and Emanuel, 2006). Recent analyses (reviewed by Kerr, 2008), however, suggested only a modest increase, or even a decrease, in the frequency and intensity of future Atlantic cyclones. Knutson et al. (2007) predicted a modest $18 \%$ decrease in the frequency of Atlantic hurricanes by the end of the 21 st century and a few percent increase in the intensity of storms. On the other hand, Emanuel et al. (2008) forecasted a few percent increase in storm frequency and a 7.5\% increase in storm intensity. A recent model by Bender et al. (2010) projects nearly a doubling of the frequency of category 4 and 5 storms by the end of the 21 st century, despite a decrease in the overall frequency of tropical cyclones with the increase projected to occur in the Western Atlantic, north of $20^{\circ} \mathrm{N}$. The impacts of hurricanes and tropical storms on stratification and how much they temporarily alleviate hypoxia in the coastal waters of the northern Gulf of Mexico depend on several factors (Rabalais et al., 2007), which include barometric pressure, wind speed, storm trajectory, forward speed, and circumference of the wind and wave field. If hurricanes occur during the hypoxia season, then there will only be transient dissipation of hypoxia. If they occur later in the summer, restratification may be slowed by an increasing frequency of fall-winter storms (mixing and thermal turnover).
The rates of biological processes, including both photosynthesis and respiration, are expected to increase with higher water temperatures up to a point. For instance, primary production may proceed at a faster rate but will eventually become limited by light (self-shading) or lack of nutrients. In addition, organisms will be brought closer to their thermal limits. These two factors, when combined, may result in a decrease in the physiological capacity of aerobic organisms (Pörtner and Knust, 2007).

Increased precipitation will result in more water, sediments and nutrients reaching the coastal zone where they are likely to enhance eutrophication through nutrient-enhanced production, increased stratification, or both (Cloern, 2001; Rabalais, 2004). The upper part of the Mississippi River watershed falls within the area of North America predicted to experience increased runoff (higher precipitation) and earlier peak discharge (increased temperature) (IPCC, 2007; Milliman et al., 2008). An increase in precipitation (10 to $30 \%$ per century) should result in increased erosion and loss of phosphorus and increased flux of dissolved inorganic nitrogen, particularly nitrate, through the soils and artificially drained agriculture areas. An increase in the water base flow, due to enhanced seasonal snow melt, is predicted to result in a 1 to 2 week earlier peak stream flow. The spring peak delivery of nutrients and freshwater to the northern Gulf of Mexico begins a seasonal cycle of increased primary production and flux of organic matter to bottom waters that subsequently lead to low oxygen concentrations (Rabalais et al., 2007a). The combination of increased nutrient loads (from human activities) and increased freshwater discharge (from GCC) will aggravate the already high loads of nutrients from the Mississippi River to the northern Gulf of Mexico, strengthen stratification (all other factors remaining the same), and worsen the hypoxia situation (Justić et al., 2003a, b; Rabalais et al., 2009). Reduced precipitation, on the other hand, will lower the amount of nutrients and water reaching the coastal zone and, perhaps, lead to oligotrophication and reduced fisheries productivity (Nixon, 2004), or perhaps alleviate hypoxia. The increase or decrease in flow (whichever occurs), flux of nutrients and water temperature are likely to have important, but as yet not clearly identifiable, influences on hypoxia.

\subsection{Oceanic waters}

Oxygen-poor waters, including OMZs, occupy large volumes of the intermediate-depth eastern tropical oceans. Oxygen-poor conditions have far-reaching impacts on ecosystems because important mobile macro-organisms avoid or cannot survive in hypoxic zones. Climate models predict declines in oceanic dissolved oxygen produced by global warming or increased atmospheric $\mathrm{CO}_{2}$ or both. Gilbert et al. (2009) determined that the number of negative trend oxygen records for ocean waters $>100 \mathrm{~km}$ from shore has significantly increased in the 1976-2000 period relative to $1951-1975$. 
As a consequence of GCC, predictions are for oceanic dissolved oxygen to decline (Minami et al., 1999; Shaffer et al., 2009). This lower oxygen concentration will be most noticeable in OMZs as they expand in area and extend into shallower depths, and as already low oxygen concentrations decline further. There could be a $50 \%$ increase in OMZs by 2100 (Riebesell et al., 2007; Arrigo, 2007). The dissolved oxygen in the core of the tropical eastern Pacific OMZs is decreasing and reached $40 \mu \mathrm{mol} \mathrm{kg} \mathrm{kg}^{-1}$ in 2008 (Stramma et al., 2008). With climate change, predictions are for global ocean oxygen outgassing to occur at a rate of $0.23 \pm 0.10$ to $0.40 \mathrm{~mol} \mathrm{~m}^{-2} \mathrm{yr}^{-1}$ by 2100 (Matear et al., 2000; Bopp et al., 2002; Frölicher et al., 2009). Stramma et al. (2008) constructed 50-year time series of dissolved-oxygen concentration for select tropical oceanic regions by augmenting a historical database with recent measurements. These time series revealed vertical expansion of the intermediate-depth lowoxygen zones in the eastern tropical Atlantic and the equatorial Pacific during the past $50 \mathrm{yr}$. The oxygen decrease in the 300- to $700-\mathrm{m}$ layer was 0.09 to $0.34 \mu \mathrm{mol} \mathrm{kg}^{-1} \mathrm{yr}^{-1}$. These declines, however, are barely significant given the cumulative oxygen content for the 300- to 700-m layer. Using the data in Stramma et al. (2008), it would take $38 \mathrm{yr}$ to reduce the oxygen content in this layer by $5 \%$. Organisms are not likely to respond to this small shift, but might if the trend continued for another $200 \mathrm{yr}$. Over longer time scales (ca. $100000 \mathrm{yr}$ ), Shaffer et al. (2009) project severe, longterm ocean oxygen depletion, as well as a great expansion of ocean oxygen-minimum zones for scenarios with high emissions of carbon dioxide or high climate sensitivity. They predict that decreased oxygen solubility from surface-layer warming will account for most of the enhanced oxygen depletion in the upper $500 \mathrm{~m}$ of the open ocean.

Ocean scientists typically ignore the $\mathrm{CO}_{2}$ side of the respiration equation, on the unspoken assumption that $p \mathrm{CO}_{2}$ levels are low and are inversely proportional to the $\mathrm{O}_{2}$ concentration via bacterial oxidation of marine organic matter. However, this may no longer be the case as Brewer and Peltzer (2009) predict that increasing atmospheric $\mathrm{CO}_{2}$ concentrations reset ocean chemical relations so that oceanic oxygen minimum zones will grow in size. Rising temperatures will further exacerbate the growth of low oxygen areas by decreasing the oxygen solubility of the water.

At global scales ocean oxygen is closely linked to climate (Pearce et al., 2008; Frölicher et al., 2009; Shaffer et al., 2009), but more data collection and modeling efforts are needed to better understand the mechanisms and implications. While anthropogenic forcing of climate is well documented (IPCC, 2007), whether anthropogenic nutrients may further intensify declining oxygen at ocean basin scales and lead to expanded OMZ and anoxic condition is an issue of great concern. There is evidence for a higher proportion of declining oxygen trends near coastlines $(<30 \mathrm{~km}$ distance $)$ than in the open ocean, most probably due to runoff of nutrients in the coastal region (Gilbert et al., 2009). Anthro- pogenic nutrients have also been implicated in expanding the OMZ along the west coast of India (Naqvi et al., 2000). Over the last 50 to $100 \mathrm{yr}$ the Baltic Sea has been tipped into semipermanent anoxia by human action (Karlson et al., 2004). Similarly in the Black Sea, eutrophication is responsible for part of the expansion and shallowing of the suboxic zone (Oguz, 2005).

\section{Conclusions}

The ecosystems considered by SCOR WG 128 on "Natural and Human-Induced Hypoxia and Consequences for Coastal Areas" have different dominant time and spatial scales of variability. Time scales range from hourly and days to seasonal events lasting weeks to months or to persistent yearround hypoxia. Near coastal systems linked to climate modes like El Niño Southern Oscillation can also develop severe hypoxia when modes are shifted. The ecosystems in which hypoxia occurs range from inshore estuaries, through the coastal ocean and into ocean waters, over depths of 1- to 2-m in estuaries to $600-$ to $700-\mathrm{m}$ in the open ocean and vary in physiography, physical processes, organic and nutrient loading, and ecosystem structure. The richness of temporal and spatial scales helps us understand the basic dynamics of hypoxia, changes in relation to anthropogenic and climate forcing, and the potential for recovery of ecosystems from hypoxia.

There is no doubt that the increase in the areas within the global coastal and open oceans with hypoxia is real. Coastal water quality with regard to oxygen is currently on the decline, and the future, based on the continued increase in the global occurrence of hypoxia and current and projected increased loads of nutrients, is trending to more hypoxia. The formation of hypoxic areas has been exacerbated by any combination of interactions that increase primary production and accumulation of organic carbon leading to increased respiratory demand for oxygen below a seasonal or permanent pycnocline. The likelihood of strengthened stratification alone, from increased surface water temperature as the global climate warms, is sufficient to worsen hypoxia where it currently exists and facilitate its formation in additional coastal waters. The interplay of increased nutrients and stratification may be offset temporarily by the potential for favorable climate modes or more frequent and/or severe tropical storm systems. The tropical storm projections with increased global temperatures, however, remain under debate. The overall forecast is for hypoxia to worsen, with increased occurrence, frequency, intensity, and duration. The consequences of global warming and climate change are effectively uncontrollable at least in the near term. On the other hand, the consequences of eutrophication-induced hypoxia can be reversed if long-term, broad-scale, and persistent efforts to reduce substantial nutrient loads are developed and implemented. The need for water and resource managers to 
reduce nutrient loads even, if at a minimum, to maintain the current status, is critical in view of globally expanding hypoxia.

Acknowledgements. We thank the many researchers whose work serves as the basis of this publication. H. Greening, Tampa Bay Estuary Program, provided updated information on recovery of the Tampa Bay estuary following nutrient remediation. B. Babin drafted Fig. 10. Funding for preparation of this publication to N. N. Rabalais, R. E. Turner and R. J. Díaz is from the National Oceanic and Atmospheric Administration, Center for Sponsored Coastal Ocean Research. This is publication number 130 of the NOAA CSCOR NGOMEX program and 3056 of the Virginia Institute of Marine Science.

Edited by: S. W. A. Naqvi

\section{References}

Alexander, R. B., Smith, R. A., and Schwarz, G. E.: Differences in phosphorus and nitrogen delivery to the Gulf of Mexico from the Mississippi River basin, Environ. Sci. Technol., 42, 822-830, 2008.

Andrews, M. J. and Rickard, D. G.: Rehabilitation of the inner Thames estuary, Mar. Pollut. Bull., 11, 327-332, 1980.

Arntz, W. E., Gallardo, V. A., Gutiérrez, D., Isla, E., Levin, L. A., Mendo, J., Neira, C., Rowe, G. T., Tarazona, J., and Wolff, M.: El Niño and similar perturbation effects on the benthos of the Humboldt, California, and Benguela Current upwelling ecosystems, Adv. Geosci., 6, 243-265, 2006,

http://www.adv-geosci.net/6/243/2006/.

Arrigo, K. R.: Marine manipulations, Nature, 450, 491-492, 2007.

Baden, S. P., Loo, L.-O., Pihl, L., and Rosenberg, R.: Effects of eutrophication on benthic communities including fish Swedish west coast, Ambio, 19, 113-122, 1990a.

Baden, S. P., Pihl, L., and Rosenberg, R.: Effects of oxygen depletion on the ecology, blood physiology and fishery of the Norway lobster Nephrops norvegicus, Mar. Ecol. Prog. Ser., 67, 141-155, 1990b.

Baird, D., Christian, R. R., Peterson, C. H., and Johnson, G. A.: Consequences of hypoxia on estuarine ecosystem function Energy diversion from consumers to microbes, Ecol. Appl., 14, 805-822, 2004.

Bakan, G. and Buyukgungor, H.: The Black Sea, Mar. Pollut. Bull., 41, 24-43, 2000.

Bakun, A.: Global climate change and intensification of coastal ocean upwelling, Science, 247, 198-201, 1990.

Bakun, A. and Weeks, S. J.: Greenhouse gas buildup, sardines, submarine eruptions, and the possibility of abrupt degradation of intense marine upwelling ecosystems, Ecol. Lett., 7, 1015-1023, 2004.

Banse, K.: On upwelling and bottom trawling off the Southwest coast off India, J. Mar. Biol. Assoc. India, 1, 33-49, 1959.

Banse, K.: Hydrograghy of the Arabian Sea shelf of India and Pakistan and effects on demersal fishes, Deep-Sea Res. I, 15, 45-79, 1968.

Barmawidjaja, D. M., van der Zwaan, G. J., Jorissen, F. J., and Puskaric, S.: 150 years of eutrophication in the northern Adriatic
Sea Evidence from a benthic foraminiferal record, Mar. Geol., 122, 367-384, 1995.

Barth, J. A., Menge, B. A., Lubchenco, J., Chan, F., Bane, J. M., Kirincich, A. R., McManus, M. A., Nielsen, K. J., Pierce, S. D., and Washburn, L.: Delayed upwelling alters nearshore coastal ocean ecosystems in the northern California current, P. Natl. Acad. Sci. USA, 104, 3719-3724, 2007.

Batiuk, R. A., Breitburg, D. L., Diaz, R. J., Cronin, T. M., Secor, D. H., and Thursby, G.: Derivation of habitat-specific dissolved oxygen criteria for Chesapeake Bay and its tidal tributaries, J. Exp. Mar. Biol. Ecol., 238, S204-S215, 2009.

Baustian, M. M. and Rabalais, N. N.: Seasonal composition of benthic macroinfauna exposed to hypoxia in the northern Gulf of Mexico, Estuar. Coasts, 32, 975-983, 2009.

Bender, M. A., Knutson, T. R., Tuleya, R. E., Sirutis, J. J., Vecchi, G. A., Barner,S. T., and Held, I. M.: Modeled impact of anthropogenic warning on the frequency of intense Atlantic hurricanes, Science, 327, 454-458, 2010.

Bennett, E. M., Carpenter, S. R., and Caraco, N. F.: Human impact on erodable phosphorus and eutrophication A global perspective, BioScience, 51, 227-234, 2001.

Benović, A., Justić, D., and Bender, A.: Enigmatic changes in the hydromedusan fauna of the northern Adriatic Sea, Nature, 326, 597-600, 1987.

Berelson, W. M.: The flushing of two deep-sea basins, Southern California Borderland, Limnol. Oceanogr., 36, 1150-1166, 1991.

Berezina, N. A.: Spatial distribution of macrofauna in a littoral zone with drifting macroalgae in the Neva estuary, Estonian J. Ecol., 57, 198-213, 2008.

Boesch, D. F.: Challenges and opportunities for science in reducing nutrient over-enrichment of coastal ecosystems, Estuaries, 25, 744-758, 2002.

Boesch, D.F.: Scientific requirements for ecosystem-based management in the restoration of Chesapeake Bay and coastal Louisiana, Ecol. Eng., 26, 6-26, 2006.

Boesch, D. F. and Rabalais, N. N.: Effects of hypoxia on continental shelf benthos Comparisons between the New York Bight and the Northern Gulf of Mexico, in: Modern and Ancient Continental Shelf Anoxia, edited by: Tyson, R. V. and Pearson, T. H., Geol. Soc. Spec. Publ. 58, The Geological Society, London, 27-34, 1991.

Bograd, S. J., Castro, C. G., Di Lorenzo, E., Palacios, D. M., Bailey, H. R., and Gilly, W.: The shoaling of the hypoxic boundary in the California Current, Geophys. Res. Let., 35, L12607, doi:10.1029/2008GL034185, 2008.

Bopp, L., LeQuéré, C., Heimann, M., Manning, A. C., and Monfray, P.: Climate-induced oceanic oxygen fluxes Implications for the contemporary carbon budget, Global Biogeochem. Cy., 16, 1022, doi:10.10292001GB001445, 2002.

Boynton, W. R., Garber, J. H., Summers, R., and Kemp, W. M.: Inputs, transformations, and transport of nitrogen and phosphorus in Chesapeake Bay and selected tributaries, Estuaries, 18, 285314, 1995.

Brand, T. D. and Griffiths, C.: Seasonality in the hydrography and biogeochemistry across the Pakistan margin of the NE Arabian Sea, Deep-Sea Res. II, 56, 283-295, 2009.

Brandt, S. B. and Kirsch, J. A. Y.: Spatially explicit models of striped bass growth potential in Chesapeake Bay, Trans. Am. 
Fish. Soc., 122, 845-869, 1993.

Brearley, A.: Ernest Hodgkin's Swanland Estuaries and Coastal Lagoons of South-western Australia, University of Western Australia Press, Crawley, Australia, 550 pp., 2005.

Breitburg, D. L.: Episodic hypoxia in Chesapeake Bay Interacting effects of recruitment, behavior, and physical disturbance, Ecol. Monogr., 62, 525-546, 1992.

Breitburg, D. L., Hondorp, D. W., Davias, L. W., and Diaz, R. J.: Hypoxia, nitrogen and fisheries Integrating effects across local and global landscapes, Ann. Rev. Mar. Sci., 1, 329-350, 2009.

Brewer, P. G. and Peltzer, E. T.: Limits to marine life, Science, 324, 347-348, 2009.

Bricker, S., Longstaff, B., Dennison, W., Jones, A., Boicourt, K., Wicks, C., and Woerner, J.: Effects of nutrient enrichment in the Nation's estuaries A decade of change. NOAA Coastal Ocean Program Decision Analysis Series No. 26, National Centers for Coastal Ocean Science, Silver Spring, Maryland, 328 pp., 2007.

Brill, R. W.: Selective advantages conferred by the high performance physiology of tunas, billfishes, and dolphin fish, Comp. Biochem. Physiol., 113, 3-15, 1996.

Brongersma-Sanders, M.: Mass mortality in the sea, in: Hedgpeth, J. W. (ed.), Treatise on Marine Ecology and Paleoecology, Vol. 1, Waverly Press, Baltimore, Maryland, 941-1010, 1957.

Brown, C. A., Nelson, W. G., Boese, B. L., DeWitt, T. H., Eldridge, P. M., Kaldy, J. E., Lee II, H., Power, J. H., and Young, D. R.: An approach to developing nutrient criteria for Pacific northwest estuaries A case study of Yaquina Estuary, EPA/600/R-07/046, Oregon, U.S. Environmental Protection Agency, Washington, DC, 183 pp., 2007.

Brush, G. S.: Stratigraphic evidence of eutrophication in an estuary, Water Resour. Res., 20, 531-541, 1984.

Brush, G. S.: Historical land use, nitrogen, and coastal eutrophication A paleoecological perspective, Estuar. Coasts, 32, 18-28, 2009.

Caddy, J. F.: Towards a comparative evaluation of human impacts on fishery ecosystems of enclosed and semi-enclosed seas, Rev. Fish. Sci., 1, 57-95, 1993.

Chabot, D. and Dutil, J.-D.: Reduced growth of Atlantic cod in non-lethal hypoxic conditions, J. Fish Biol., 55, 472-491, 1999.

Chapman, P. and Shannon, L. V.: The Benguela ecosystem Part II Chemistry and related processes, Oceanogr. Mar. Biol. Ann. Rev., 23, 183-251, 1985.

Chan, F., Barth, J., Lubchenco, J., Kirincich, J., Weeks, A., Peterson, H., Mengl, W. T., and Chan, B. A.: Emergence of anoxia in the California Current Large Marine Ecosystem, Science, 319, p. 920,2008

Chavez, F. P., Ryan, J., Lluch-Cota, S. E., and Ñiquen, C. M.: From anchovies to sardines and back Multidecadal change in the Pacific Ocean, Science, 299, 217-221, 2003.

Cheek, T. E., Van Den Avyle, M. J., and Coutant, C. C.: Influence of water quality on distribution of striped bass in a Tennessee River impoundment, Trans. Am. Fish. Soc., 114, 67-76, 1985.

Chen, C.-C., Gong, G.-C., and Shiah, F.-K.: Hypoxia in the East China Sea One of the largest coastal low-oxygen areas in the world, Mar. Environ. Res., 64, 399-408, 2007.

Chen, G. H., Leong, I. M., Liu, J., Huang, J. C., Lo, I. M. C., and Yen, B. C.: Oxygen deficit determinations for a major river in eastern Hong Kong, China, Chemosphere, 41, 7-13, 2000.

Chen, T. A. C. and Wang, S. L.: Carbon, alkalinity and nutrient budgets on the East China Sea continental shelf, J. Geophy. Res., 104, 20675-20686, 1999.

Cheng W., Liu, C.-H., Hsu, J.-P., and Chen, J.-C.: Effect of hypoxia on the immune response of giant freshwater prawn Macrobrachium rosenbergii and its susceptibility to pathogen Enterococcus, Fish Shellfish Immunol., 13, 351-365, 2002.

Cheung, W. W. L., Lam, V. W. Y., Sarmiento, J. L., Kearney, K., Watson, R., Zeller, D., and Pauly, D.: Large-scale redistribution of maximum fisheries catch potential in the global ocean under climate change, Glob. Change Biol., 16, 24-35, 2010.

Childress, J. J. and Seibel, B. A.: Life at stable low oxygen levels Adaptations of animals to oceanic oxygen minimum layers, J. Exp. Biol., 201, 1223-1232, 1998.

Childs, C. R., Rabalais, N. N., Turner, R. E., and Proctor, L. M.: Sediment denitrification in the Gulf of Mexico zone of hypoxia, Mar. Ecol. Prog. Ser., 240, 285-290, (Erratum, 247, p. 310, 2003), 2002.

Christie, N. D. and Moldan, A. G. S.: Effects of fish factory effluents on the benthic macrofauna of Saldanha Bay, Mar. Pollut. Bull., 8, 41-45, 1977.

Cloern, J. E.: Review Our evolving conceptual model of the coastal eutrophication problem, Mar. Ecol. Prog. Ser., 210, 223-253, 2001.

Cockroft, A. C.: Jasus lalandii "walkouts" or mass strandings in South Africa during the 1990's An overview, Mar. Freshwater Res., 52, 1085-1094, 2001.

Committee on Environment and Natural Resources (CENR): Integrated Assessment of Hypoxia in the Northern Gulf of Mexico, National Science and Technology Council, Washington, DC, 2000.

Conley, D. J. and Josefson, A. B.: Hypoxia, nutrient management and restoration in Danish waters, in: Coastal Hypoxia Consequences for Living Resources and Ecosystems, edited by: Rabalais, N. N. and Turner, R. E., Coastal and Estuarine Studies 58 , Washington, DC, American Geophysical Union, 425-434, 2001.

Conley, D. J., Humborg, C., Rahm, L., Savchuk, O. P., and Wulff, F.: Hypoxia in the Baltic Sea and basin-scale changes in phosphorus biogeochemistry, Environ. Sci. Technol., 36, 5315-5320, 2002a.

Conley, D. J., Markager, S., Andersen, J., Ellermann, T., and Svendsen, L. M.: Coastal eutrophication and the Danish National Aquatic Monitoring and Assessment Program, Estuaries, 25, 848-861, 2002b.

Conley, D. J., Carstensen, J., Ærtebjerg, G., Christensen, P. B., Dalsgaard, T., Hansen, J. L. S., and Josefson, A. B.: Long-term changes and impacts of hypoxia in Danish coastal waters, Ecol Appl., 17, Suppl., S165-S184, 2007.

Conley, D. J., Bonsdorff, E., Carstensen, J., Destouni, G., Gustafsson, B. G., Hansson, L.-A., Rabalais, N. N., Voss, M., and Zillén, L.: Tackling hypoxia in the Baltic Sea Is engineering a solution?, Environ. Sci. Technol., 43, 3407-3411, 2009a.

Conley, D. J., Björck, S., Bonsdorff, E., Carstensen, J., Destouni, G., Gustafsson, B. G., Hietanen, S., Kortekaas, M., Kuosa, H., Meier, H. E. M., Müller-Karulis, B., Nordberg, K., Norkko, A., Nürrnberg, G., Pitkänen, H., Rabalais, N. N., Rosenberg, R., Savchuk, O., Slump, C. P., Voss, M., Wulff, F., and Zillén, L. Hypoxia-related processes in the Baltic Sea, Environ. Sci. Technol., 43, 3412-3420, 2009b.

Conseil Permanent International pour l'Exploration de la Mer: Bul- 
letin Hydrographique pour l'année 1935, Series B1, Charlottelund Slot, Denmark: Le Bureau du Conseil, Service Hydrographique, 1936.

Cooper, S. R. and Brush, G. S.: Long term history of Chesapeake Bay anoxia, Science, 254, 992-996, 1991.

Costanza, R., d'Arge, R., de Groot, R. S., Farber, S., Grasso, M., Hannon, B., Limburg, K., Naeem, S., O’Neill, R.V., Paruelo, J., Raskin, R. G., Sutton, P., and van den Belt, M.: The value of the world's ecosystem services and natural capital, Nature, 387, 253-260, 1997.

Coutant, C. C. and Benson, D. L.: Summer habitat suitability for striped bass in Chesapeake Bay Reflections on a population decline, Trans. Am. Fish. Soc., 119, 757-778, 1990.

Craig, J. K., Crowder, L. B., and Henwood, T. A.: Spatial distribution of brown shrimp (Farfantepenaeus aztecus) on the northwestern Gulf of Mexico shelf Effects of abundance and hypoxia, Can. J. Fish. Aquat. Sci., 62, 1295-1308, 2005.

Crema, R., Castelli, A., and Prevedelli, D.: Long term eutrophication effects on macrofaunal communities in Northern Adriatic Sea, Mar. Pollut. Bull., 22, 503-508, 1991.

Dagg, M. J.: Physical and biological responses to the passage of a winter storm in the coastal and inner shelf waters of the northern Gulf of Mexico, Cont. Shelf. Res., 8, 167-178, 1988.

Dauer D. M., Rodi Jr., A. J., and Ranasinghe, J. A.: Effects of low dissolved oxygen events on the macrobenthos of the lower Chesapeake Bay, Estuaries, 15, 384-391, 1992.

deGroot, R. S., Wilson, M. A., and Boumans, R. M. J.: A typology for the classification, description and valuation of ecosystem functions, good and services, Ecol. Econom., 41, 393-408, 2002.

Díaz, R. J.: Overview of hypoxia around the world, J. Environ. Qual., 30, 275-281, 2001.

Díaz, R. J. and Breitburg, D. L.: The hypoxic environment, in: Fish Physiology, edited by: Richards, J. G., Farrell, A. P., and Brauner, C. J., Vol. 27, Academic Press, Burlington, 1-23, 2009.

Díaz, R. J. and Rosenberg, R.: Marine benthic hypoxia A review of its ecological effects and the behavioural responses of benthic macrofauna, Oceanogr. Mar. Biol. Ann. Rev., 33, 245-303, 1995.

Díaz, R. J. and Rosenberg, R.: Spreading dead zones and consequences for marine ecosystems, Science, 321, 926-929, 2008.

Donner, S. D., Coe, M. T., Lenters, J. D., Twine, T. E., and Foley, J. A.: Modeling the impact of hydrological changes on nitrate transport in the Mississippi River basin from 1955 to 1994, Global Biogeochem. Cy., 16, 1043, doi:10.1029/2001GB001396, 2002.

Dortch, Q., Rabalais, N. N., Turner, R. E., and Qureshi, N. A.: Impacts of changing $\mathrm{Si} / \mathrm{N}$ ratios and phytoplankton species composition, in: Coastal Hypoxia Consequences for Living Resources and Ecosystems, edited by: Rabalais, N. N. and Turner, R. E., Coastal and Estuarine Studies 58, American Geophysical Union, Washington DC, 37-48, 2001.

Eby, L. A. and Crowder, L. B.: Hypoxia-based habitat compression in the Neuse River estuary Context-dependent shifts in behavioral avoidance thresholds, Can. J. Fish. Aquat. Sci., 59, 952965, 2002.

Eilola, K., Meier, H. E. M., and Almroth, E.: On the dynamics of oxygen, phosphorus and cyanobacteria in the Baltic Sea A model study, J. Mar. Syst., 75, 163-184, 2009.

Ekau, W., Auel, H., Pörtner, H.-O., and Gilbert, D.: Impacts of hypoxia on the structure and processes in the pelagic commu- nity (zooplankton, macro-invertebrates and fish), Biogeosciences Discuss., 6, 5073-5144, 2009,

http://www.biogeosciences-discuss.net/6/5073/2009/.

Elmgren, R.: Man's impact on the ecosystem of the Baltic Sea Energy flows today and at the turn of the century, Ambio, 18, 326332, 1989.

Emanuel, K., Sundararajan, R., and Williams, J.: Hurricanes and global warming, results from downscaling IPCC AR4 simulations, B. Am. Meteorol. Soc., 89, 347-364, 2008.

Emeis, K.-C., Brüchert, V., Currie, B., Endler, R., Ferdelman, T., Kiessling, A., Leipe, T., Noli-Peard, K., Struck, U., and Vogt, T.: Shallow gas in shelf sediments off the Namibian coastal upwelling ecosystem, Cont. Shelf Res., 24, 627-642, 2004.

Escribano, R. and Schneider, W.: The structure and functioning of the coastal upwelling system off south/central Chile, Prog. Oceanogr., 75, 343-346, 2007.

Escribano, R., Daneri, G., Farías, L., Gallardo, V. A., González, A., Gutiérrez, D., Lange, C. B., Morales, C., Pizarro, O., Ulloa, O., and Braun, M.: Biological and chemical consequences of the 1997-1998 El Niño in the Chilean coastal upwelling system A synthesis, Deep-Sea Res. II, 51, 2389-2411, 2004.

Fallesen, G., Andersen, F., and Larsen, B.: Life, death and revival of the hypertrophic Mariager Fjord, Denmark, J. Mar. Syst., 25, 313-321, 2000.

Farías, L. and Cornejo, M.: Effect of seasonal changes in bottom water oxygenation on sediment $\mathrm{N}$ oxides and $\mathrm{N}_{2} \mathrm{O}$ cycling in the coastal upwelling regime off central Chile $\left(36.5^{\circ} \mathrm{S}\right)$, Prog. Oceanogr., 75, 561-575, 2007.

Fish and Wildlife Research Institute (FWRI): Offshore red tideassociated mortalities and FWRI event response, 2005.

Flemer, D. A., Kruczynski, W. L., Ruth, B. F., and Bundrick, C. M.: The relative influence of hypoxia, anoxia, and associated environmental factors as determinants of macrobenthic community structure in a northern Gulf of Mexico estuary, J. Aquat. Ecosys. Stress Recov., 6, 311-328, 1999.

Flindt, M. R., Kamp-Nielsen, L., Marques, J. C., Pardal, M. A., Bocci, M., Bendoricchio, G., Salomonsen, J., Nielsen, S. N., and Jorgensen, S. E.: Description of the three shallow estuaries Mondego River (Portugal), Roskilde Fjord (Denmark) and the Lagoon of Venice (Italy), Ecol. Model., 102, 17-31, 1997.

Fonfonoff, P. and Millard Jr., R. C.: Algorithms for computation of fundamental properties of seawater, UNESCO Tech. Papers in Mar. Sci., 44, 53 pp., 1983.

Fonselius, S. H.: Hydrography of the Baltic deep basins III, in: Series Hydrography Report No. 23, Fishery Board of Sweden, Gothenberg, 1-97, 1969.

Frölicher, T. L., Joos, F., Plattner, G.-K., Steinacher, M., and Doney, S. C.: Natural variability and anthropogenic trends in oceanic oxygen in a coupled carbon cycle-climate model ensemble, Global Biogeochem. Cy., 23, GB1003, doi:10.1029/2008GB003316, 2009.

Fuenzalida, R, Schneider, W., Graces-Vargas, J., Bravo, L., and Lange, C.: Vertical and horizontal extension of the oxygen minimum zone in the eastern South Pacific Ocean, Deep-Sea Res. II, 56, 992-1003, 2009.

Gallardo, V. A.: Large benthic microbial communities in sulfide biota under Peru-Chile subsurface countercurrent, Nature, 268, 331-332, 1977.

Galloway, J. N. and Cowling, E. B.: Reactive nitrogen and the world 
200 years of change, Ambio, 31, 64-71, 2002.

Galloway, J. N., Dentener, F. J., Capone, D. G., Boyer, E. W., Howarth, R. W., Seitzinger, S. P., Asner, G. P., Cleveland, C. C., Green, P. A., Holland, E. A., Karl, D. M., Michaels, A. F., Porter, J. H., Townsend A. R., and Vörösmarty, C. J.: Nitrogen cycles past, present, and future, Biogeochemistry, 70, 153-226, 2004.

Galloway, J. N., Townsend, A. R., Erisman, J. W., Bekunda, M., Cai, Z., Freney, J. R., Martinelli, L. A., Seitzinger, S. P., and Sutton, M. A.: Transformation of the nitrogen cycle Recent trends, questions, and potential solutions, Science, 320, 889-892, 2008.

Gerlach, S. A.: Oxygen conditions improve when the salinity in the Baltic Sea decreases, Mar. Pollut. Bull., 28, 413-416, 1994.

Gilbert, D., Chabot, D., Archambault, P., Rondeau, B., and Hébert, S.: Appauvrissement en oxygène dans les eaux profondes du Saint-Laurent marin Causes possibles et impacts écologiques, Le Naturaliste Canadien, 131, 67-75, 2007.

Gilbert, D., Sundby, B., Gobeil, C., Mucci, A., and Tremblay, G.H.: A seventy-two year record of diminishing deep-water oxygen in the St. Lawrence estuary The northwest Atlantic connection, Limnol. Oceanogr., 50, 1654-1666, 2005.

Gilbert, D., Rabalais, N. N., Diaz, R. J., and Zhang, J.: Evidence for greater oxygen decline rates in the coastal ocean than in the open ocean, Biogeosciences Discuss., 6, 9127-9160, 2009, http://www.biogeosciences-discuss.net/6/9127/2009/.

Gillibrand, P. A., Turrell, W. R., Moore, D. C., and Adams, R. D.: Bottom water stagnation and oxygen depletion in a Scottish sea loch, Estuar. Coast. Shelf Sci., 43, 217-235, 1996.

Gooday, A. J., Jorissen, F., Levin, L. A., Middelburg, J. J., Naqvi, S. W. A., Rabalais, N. N., Scranton, M., and Zhang, J.: Historical records of coastal eutrophication-induced hypoxia, Biogeosciences, 6, 1707-1745, 2009a, http://www.biogeosciences.net/6/1707/2009/.

Gooday, A. J., Levin, L. A., Aranda da Silva, A., Bett, B., Cowie, G., Dissard, D., Gage, J., Hughes, D., Jeffreys, R., Larkin, K., Murty, S. J., Shumaker, S, Whitcraft, C., and Woulds, C.: Faunal responses to oxygen gradients on the Pakistan margin A comparison of foraminifera, macrofauna and megafauna, Deep-Sea Res. II, 56, 488-502, 2009b.

Graco, M., Farías, L., Molina, V., Gutiérrez, D., and Nielsen, L. P.: Massive developments of microbial mats following phytoplankton blooms in a eutrophic bay II Implications for nitrogen cycling, Limnol. Oceanogr., 46, 821-832, 2001.

Graham, J. B.: Ecological, evolutionary, and physical factors influencing aquatic animal respiration, Am. Zool., 30, 137-146, 1990.

Grall, J. and Chauvaud, L.: Marine eutrophication and benthos The need for new approaches and concepts, Global Change Biol., 8, 813-830, 2002

Grantham B. A., Chan, F., Nielsen, K. J., Fox, D. S., Barth, .J. A., Huyer, A., Lubchenco, J., and Menge, B. A.: Upwelling-driven nearshore hypoxia signals ecosystem and oceanographic changes in the northeast Pacific, Nature, 429, 749-754, 2004.

Gray, J. S., Wu, R. S. S., and Or, Y. Y.: Effects of hypoxia and organic enrichment on the coastal marine environment, Mar. Ecol. Prog. Ser., 238, 249-279, 2002.

Greene, R. M., Lehrter, J. C., and Hagy III, J. D.: Multiple regression models for hindcasting and forecasting midsummer hypoxia in the Gulf of Mexico, Ecol. Appl., 19, 1161-1175, 2009.
Greening, H. and Janicki, A.: Toward reversal of eutrophic conditions in a subtropical estuary Water quality and seagrass response to nitrogen loading reductions in Tampa Bay, Florida, USA, Environ. Manage., 38, 163-178, 2006.

Grimes, C. B.: Fishery production and the Mississippi River discharge, Fisheries, 26, 17-26, 2001.

Gu, H. K., Ma, X. N., Shen, W. R., Ren, G. F., Chen, Z., Diao, H. X., Li, G. J., and Zhang, L. Y.: Marine geochemistry of nitrogen near estuary of Changjiang River II Nitrite and ammonia in sea water near estuary, J. Shandong Coll. Oceanol., 12, 31-38, 1982 (in Chinese).

Gu, H. K., Xiong X. X., Liu, M. X., and Li, Y.: Marine geochemistry of nitrogen near estuary of Yangtze River I Nitrate in sea water near estuary, J. Shandong Coll. Oceanol., 11, 37-46, 1981 (in Chinese).

Gunter, G.: The fertile fisheries crescent, J. Mississippi Acad. Sci., 9, 286-290, 1963.

Gutiérrez, D., Gallardo, V. A., Mayor, S., Neira, C., Vásquez, C., Sellanes, J., Rivas, M., Soto, A., Carrasco, F., and Baltazar, M.: Effects of dissolved oxygen and fresh organic matter on the bioturbation potential of macrofauna in sublittoral sediments off Central Chile during the 1997/1998 El Niño, Mar. Ecol. Prog. Ser., 202, 81-99, 2000.

Hagy, J. D., Boynton, W. R., Keefe, C. W., and Wood, K. V.: Hypoxia in Chesapeake Bay, 1950-2001 Long-term change in relation to nutrient loading and river flow, Estuaries, 27, 634-658, 2004.

Hamukuaya, H., O’Toole, M. J., and Woodhead, P. J. M.: Observations of severe hypoxia and offshore displacement of cape hake over the Namibian shelf in 1994, S. Afr. J. Marine Sci., 19, 57 59, 1998

Harper Jr., D. E., McKinney, L. D., Salzer, R. R., and Case, R. J.: The occurrence of hypoxic bottom water off the upper Texas coast and its effects on the benthic biota, Contrib. Mar. Sci., 24, 53-79, 1981.

Haug, G. H., Hughen, K. A., Sigman, D. M., Peterson, L. C., and Röhl, U.: Southward migration of the intertropical convergence zone through the Holocene, Science, 293, 1304-1308, 2001.

Helsinki Commission (HELCOM): The Baltic Sea Action Plan, Helsinki, Finland, 101 pp. online available at: http://www. helcom.fi/BSAP/en\{_\}GB/intro/, 2007.

Helly, J. J. and Levin, L. A.: Global distribution of naturally occurring marine hypoxia on continental margins, Deep-Sea Res. I, 51, 1159-1168, 2004.

Hennessey, T. M.: Governance and adaptive management for estuarine ecosystems The case of Chesapeake Bay, Coastal Manage. 22, 119-145, 1994

Henry, L. M., Kennedy, R., and Keegan, B. F.: An investigation of periodic hypoxia at Ardbear Salt Lake, J. Mar. Biol. Assoc. UK, 88, 1297-1307, 2008.

Holland, A. F., Shaughnessy, A. T., and Hiegel, M. H.: Long-term variation in mesohaline Chesapeake Bay macrobenthos spatial and temporal patterns, Estuaries, 10, 370-378, 1987.

Horton, T.: Turning the Tide Saving the Chesapeake Bay, Island Press, Washington, DC, 386 pp., 2003.

Howarth, R. W., Swaney, D. P., Butler, T. J., and Marino, R. Climate control on eutrophication of the Hudson River estuary, Ecosystems, 3, 210-215, 2000.

Hoyos, C. D., Agudelo, P. A., Webster, P. J., and Curry, J. A.: De- 
convolution of the factors contributing to the increase in global hurricane intensity, Science, 312, 94-97, 2006.

Humborg, C., Ittekkot, V., Cociasu, A., and Bodungen, B. v.: Effect of Danube River dam on Black Sea biogeochemistry and ecosystem structure, Nature, 386, 385-388, 1997.

Intergovernmental Panel on Climate Change (IPCC): Climate Change 2007 - Impacts, Adaptation and Vulnerability. Contribution of Working Group II to the Fourth Assessment Report of the Intergovernmental Panel on Climate, Change, edited by: Parry, M. L., Canziani, O. F. Palutikof, J. P., van der, van der Linden, P. J., and Hanson, C. E., Cambridge University Press, Cambridge, UK, 976 pp., 2007.

Irigoien X., Post, J., Castel, J., Pfeiffer, K. F., and Hellmann, B.: Nycthemeral variations of the dissolved oxygen concentration in the turbidity maximum of three European estuaries Biological vs. physical processes, J. Mar. Syst., 22, 173-177, 1999.

Johansson, J. O. R.: Shifts in phytoplankton, macroalgae, and seagrass with changing nitrogen loading rates to Tampa Bay, Florida, in: Proceedings Tampa Bay Area Scientific Information Symposium, edited by: Treat, S. F., BASIS4, St. Petersburg, Florida, 31-40, 2005.

Johansson, J. O. R. and Lewis III, R. R.: Recent improvements of water quality and biological indicators in Hillsborough Bay, a highly impacted subdivision of Tampa Bay, Florida, USA, in: Marine Coastal Eutrophication, The response of marine transitional systems to human impact, Problems and perspectives for restoration, edited by: Vollenweider, R. W., Marchetti, R., and Viviani, R., Elsevier Press, New York, 1191-1215, 1992.

Johnson, G. C. and Gruber, N.: Decadal water mass variations along $20^{\circ} \mathrm{W}$ in the northeastern Atlantic Ocean, Prog. Oceanogr., 73, 277-295, 2007.

Jørgensen, B. B.: Seasonal oxygen depletion in the bottom waters of a Danish fjord and its effect on the benthic community, Oikos, 34, 68-76, 1980.

Justić, D.: Trend in the transparency of the northern Adriatic Sea 1911-1982, Mar. Pollut. Bull., 19, 32-35, 1988.

Justić, D.: A simple oxygen index for trophic state description, Mar. Pollut. Bull., 22, 201-204, 1991a.

Justić, D.: Hypoxic conditions in the northern Adriatic Sea Historical development and ecological significance, in: Tyson, R. V. and Pearson, T. H. (eds.), Modern and Ancient Continental Shelf Anoxia, Geol. Soc. Spec. Publ. 58, London, The Geological Society, London, 95-105, $1991 \mathrm{~b}$.

Justić, D., Legović, T., and Rottini-Sandrini, L.: Trends in oxygen content 1911-1984 and occurrence of benthic mortality in the northern Adriatic Sea, Estuar. Coast. Shelf Sci., 25, 435-445, 1987.

Justić, D., Rabalais, N. N., and Turner, R. E.: Effects of climate change on hypoxia in coastal waters A doubled $\mathrm{CO}_{2}$ scenario for the northern Gulf of Mexico, Limnol. Oceanogr., 41, 992-1003, 1996.

Justić, D., Rabalais, N. N., and Turner, R. E.: Modeling the impacts of decadal changes in riverine nutrient fluxes on coastal eutrophication near the Mississippi River delta, Ecol. Model., 152, 33-46, 2002.

Justić, D., Rabalais, N. N., and Turner, R. E.: Stoichiometric nutrient balance and origin of coastal eutrophication, Mar. Pollut. Bull., 30, 41-46, 1995a.

Justić, D., Rabalais, N. N., Turner, R. E., and Dortch, Q.: Changes in nutrient structure of river-dominated coastal waters, stoichiometric nutrient balance and its consequences, Estuar. Coast. Shelf Sci., 40, 339-356, 1995 b.

Justić, D., Rabalais, N. N., and Turner, R. E.: Simulated responses of the Gulf of Mexico hypoxia to variations in climate and anthropogenic nutrient loading, J. Mar. Syst., 42, 115-126, $2003 \mathrm{a}$.

Justić, D., Rabalais, N. N., and Turner, R. E.: Climatic influences on riverine nitrate flux: Implications for coastal marine eutrophication and hypoxia, Estuaries, 26, 1-11, 2003b.

Kamykowski, D. and Zentara, S. J.: Hypoxia in the world ocean as recorded in the historical data set, Deep-Sea Res. I, 37, 18611874, 1990.

Karlson, K., Rosenberg, R., and Bonsdorff, E.: Temporal and spatial large-scale effects of eutrophication and oxygen deficiency on benthic fauna in Scandinavian and Baltic waters A review, Oceanogr. Mar. Biol. Ann. Rev., 40, 427-489, 2002.

Karstensen, J., Stramma, L., and Visbeck, M.: Oxygen minimum zones in the eastern tropical Atlantic and Pacific Oceans, Prog. Oceanogr., 77, 331-350, 2008.

Keeling, R. F. and Garcia, H. E.: The change in oceanic $\mathrm{O}_{2}$ inventory associated with recent global warming, P. Natl. Acad. Sci. USA, 99, 7848-7853, 2002.

Kemp, W. M., Testa, J. M., Conley, D. J., Gilbert, D., and Hagy, J. D.: Temporal responses of coastal hypoxia to nutrient loading and physical controls, Biogeosciences, 6, 2985-3008, 2009, http://www.biogeosciences.net/6/2985/2009/.

Kemp, W. M., Sampou, P., Caffrey, J., Mayer, M., Henriksen, K., and Boynton, W.: Ammonium recycling versus denitrification in Chesapeake Bay sediments, Limnol. Oceanogr., 35, 1545-1563, 1990.

Kemp, W. M., Boynton, W. R., Adolf, J. E., Boesch, D. F., Boicourt, W. C., Brush, G., Cornwell, J. C., Fisher, T. R., Glibert, P. M., Hagy, J. D., Harding, L. W., Houde, E. D., Kimmel, D. G., Miller, W. D., Newell, R. I. E., Roman, M. R., Smith, E. M., and Stevenson, J. C.: Eutrophication of Chesapeake Bay historical trends and ecological interactions, Mar. Ecol. Prog. Ser., 303, 1-29, 2005.

Kerr, R.: Global warming may be homing in on Atlantic hurricanes, Science, 314, 910-911, 2006.

Kerr, R. A.: Hurricanes won't go wild, according to climate models, Science, 320, p. 999, 2008.

Kiirikki, M., Lehtoranta, J., Inkala, A., Pitkänen, H., Hietanen, S., Hall, P., Tengberg, A., Koponen, J., and Sarkkula, J.: A simple sediment process description suitable for 3D-ecosystem modelling - development and testing in the Gulf of Finland, J. Mar. Syst., 61, 55-66, 2006.

Kodama K., Aoki, I., and Shimizu, M.: Long-term changes in the assemblage of demersal fishes and invertebrates in relation to environmental variations in Tokyo Bay, Japan, Fish. Manag. Ecol., 9, 303-313, 2002.

Konovalov, S. K. and Murray, J. W.: Variations in the chemistry of the Black Sea on a time scale of decades 1960-1995, J. Mar. Syst., 31, 217-243, 2002.

Knutson, T. R., Sirutis, J. J., Garner, S. T., Held, I. M., and Tuley, R. E.: Simulation of the recent multi-decadal increase of Atlantic hurricane activity using an 18-km-grid regional model, Bull. Am. Meteorol. Soc., 88, 1549-1565, 2007.

Kristiansen, S. and Hoell, E. E.: The importance of silicon for marine production, Hydrobiologia, 484, 21-31, 2002. 
Kump, L. R., Pavlov, A., and Arthur, M. A.: Massive release of hydrogen sulfide to the surface ocean and atmosphere during intervals of oceanic anoxia, Geology, 33, 397-400, 2005.

Kurian, S., Agnihotri, R., Borole, D. V., Naqvi, S. W. A., Ferreira, A. M., and Vale, C.: Possible solar control on primary production along the Indian west coast on decadal to centennial time scales, J. Quaternary Sci., 24, 109-116, 2009.

Levin, L. A.: Deep-ocean life where oxygen is scarce, Am. Scient., 90, 436-444, 2002.

Levin, L. A.: Oxygen minimum zone benthos adaptation and community response to hypoxia, Oceanogr. Mar. Biol. Ann. Rev., 41, $1-45,2003$.

Levin, L. A., Gage, J. D., Marti, C., and Lamont, P. A.: Macrobenthic community structure within and beneath the oxygen minimum zone, NW Arabian Sea, Deep-Sea Res. II, 47, 189-226, 2000.

Levin, L. A., Ekau, W., Gooday, A. J., Jorissen, F., Middelburg, J. J., Naqvi, S. W. A., Neira, C., Rabalais, N. N., and Zhang, J.: Effects of natural and human-induced hypoxia on coastal benthos, Biogeosciences, 6, 2063-2098, 2009a, http://www.biogeosciences.net/6/2063/2009/.

Levin, L. A., Whitcraft, C., Mendoza, G. F., Gonzalez, J., and Cowie, G.: Oxygen and organic matter thresholds for benthic faunal activity on the Pakistan Margin oxygen minimum zone (700-1100 m), Deep-Sea Res. II, 56, 449-471, 2009 b.

Li, D. and Daler, D.: Ocean pollution from land-based sources East China Sea, China, Ambio, 33, 107-113, 2004.

Li, D., Zhang, J., Huang, D., Wu, Y., and Liang, J.: Oxygen depletion off the Changjiang (Yangtze River) Estuary, Science in China Series D-Earth Sciences, 45, 1137-1146, 2002.

Lim, H.-S., Diaz, R. J., Hong, J.-S., and Schaffner, L. C.: Hypoxia and benthic community recovery in Korean coastal waters, Mar. Pollut. Bull., 52, 1517-1526, 2006.

Liu, K.-K., Atkinson, L., Quiñones, R., and Talaue-McManus, L. (eds.): Carbon and Nutrient Fluxes in Continental Margins A Global Synthesis. IGBP Book Series, Springer, Heidelberg, Germany, 744 pp., 2010.

Liu, K.-K., Seitzinger, S., Mayorga, E., Harrison, J., and Ittekkot, V.: Fluxes of nutrients and selected organic pollutants carried by rivers, in: Watersheds, Bays and Bounded Seas: The Science and Management of Semi-Enclosed Marine Systems, edited by: Urban, E. R., Sundby, B., Malanotte-Rizzoli, P., and Melillo, J. M., SCOPE 70, Island Press, Washington, DC, 141-167, 2008.

Liu, S. M., Zhang, J., Chen, H. T., Wu, Y., Xiong, H., and Zhang, Z. F.: Nutrients in the Changjiang and its tributaries, Biogeochemistry, 62, 1-18, 2003.

Lohrenz, S. E., Fahnenstiel, G. L., Redalje, D. G., Lang, G. A., Chen, X., and Dagg, M. J.: Variations in primary production of northern Gulf of Mexico continental shelf waters linked to nutrient inputs from the Mississippi River, Mar. Ecol. Prog. Ser., 155, 435-454, 1997.

Madrid, V. M., Taylor, G. T., Scranton, M. I., and Chistoserdov, A. Y.: Phylogenetic diversity of bacterial and archaeal communities in the anoxic zone of the Cariaco Basin, Appl. Environ. Microbiol. 67, 1663-1674, 2001.

Mann, M. E. and Emanuel, K. A.: Atlantic hurricane trends linked to climate change, Eos, Trans. Amer. Geophy. Union, 87, p. 233 and p. 244, 2006.

Matear, R. J., Hirst, A. C., and McNeil, B. I.: Changes in dissolved oxygen in the Southern Ocean with climate change, Geochem. Geophys. Geosyst., 1, 2000GC000086, 2000.

McGregor, H. V., Dima, M., Fischer, H. W., and Mulitza, S.: Rapid 20th-century increase in coastal upwelling off Northwest Africa, Science, 315, 637-639, 2007.

McQuatters-Gollop, A., Mee, L. D., Raitsos, D. E., and Shapiro, G. I.: Non-linearities, regime shifts and recovery: the recent influence of climate on Black Sea chlorophyll, J. Mar. Syst., 74, 649-658, 2008.

Mee, L. D.: Eutrophication in the Black Sea and a basin-wide approach to its control, in: Science and Integrated Coastal Management, edited by: von Bodungen, B. and Turner, R. K., Dahlem University Press, Berlin, 71-91, 2001.

Mee, L. D.: Reviving dead zones, Scient. Am., November 2006, 80-85, 2006.

Mee, L. D., Friedrich, J., and Gomoiu, M. T.: Restoring the Black Sea in times of uncertainty, Oceanography, 18, 100-111, 2005.

Millennium Ecosystem Assessment: Ecosystems and human wellbeing Synthesis, Island Press, Washington DC, 155 pp., 2005.

Meybeck, M.: Global analysis of river systems From earth system controls to anthropocene syndromes, Philos. T. Roy. Soc. London, 358, 1935-1955, 2003.

Meyer-Reil, L.-A. and Köster, M.: Eutrophication of marine waters effects on benthic microbial communities, Mar. Pollut. Bull., 41, 255-263, 2000.

Middelburg, J. and Levin, L. A.: Coastal hypoxia and sediment biogeochemistry, Biogeosciences, 6, 1273-1293, 2009, http://www.biogeosciences.net/6/1273/2009/.

Milliman, J. D. and Meade, R. H.: World-wide delivery of sediments to the ocean, J. Geol., 91, 1-21, 1983.

Milliman, J. D., Farnsworth, K. L., Jones, P. D., Xu, K. H., and Smith, L. C.: Climatic and anthropogenic factors affecting river discharge to the global ocean, 1951-2000, Global Planet. Change, 62, 187-194, 2008.

Minami, H., Kano, Y., and Ocawa, K.: Long-term variations of potential temperature and dissolved oxygen of the Japan Sea proper water, J. Oceanogr., 55, 197-205, 1999.

Mirza, F. B. and Gray, J. S.: The fauna of benthic sediments from the organically enriched Oslofjord, Norway, J. Exper. Mar. Biol. Ecol., 54, 181-207, 1981.

Mississippi River/Gulf of Mexico Watershed Nutrient Task Force: Action Plan for Reducing, Mitigating, and Controlling Hypoxia in the Northern Gulf of Mexico, Office of Wetlands, Oceans, and Watersheds, US Environmental Protection Agency, Washington DC, 2001.

Mississippi River/Gulf of Mexico Watershed Nutrient Task Force: Gulf Hypoxia Action Plan, Office of Wetlands, Oceans, and Watersheds, US Environmental Protection Agency, Washington, DC, 2008.

Monteiro, P., van der Plas, A., Melice, J.-L., and Florenchie, P. Interannual hypoxia variability in a coastal upwelling system Ocean-shelf exchange, climate and ecosystem-state implications, Deep-Sea Res. I, 55, 435-450, 2008.

Müller-Karger, F. E., Varela, R., Thunell, R., Scranton, M., Bohrer, R., Taylor, G., Capelo, J., Astor, Y., Tappa, E., Ho, T. Y., and Walsh, J. J.: Annual cycle of primary production in the Cariaco Basin Response to upwelling and implications for vertical export, J. Geophys. Res., 106, 4527-4542, 2001.

Müller-Karger, F. E., Varela, R., Thunell, R., Astor, Y., Zhang, H., 
Luerssen, R., and $\mathrm{Hu}, \mathrm{C} .:$ Processes of coastal upwelling and carbon flux in the Cariaco Basin, Deep-Sea Res. II, 51, 927-943, 2004.

Nakata, K., Sugioka, S.-I., and Hosaka T.: Hindcast of a Japan Sea oil spill, Spill Sci. Technol. Bull., 4, 219-229, 1997.

Naqvi, S. W. A., Jayakumar, D. A., Narvekar, P. V., Naik, H., Sarma, V. V. S. S., D'Souza, W., Joseph, S., and George, M. D.: Increased marine production of $\mathrm{N}_{2} \mathrm{O}$ due to intensifying anoxia on the Indian continental shelf, Nature, 408, 346-349, 2000.

Naqvi, S. W., Naik, H., Jayakumar, D. A., Shailaja, M. S., and Narvekar, P. V.: Seasonal oxygen deficiency over the western continental shelf of India, in: Past and Present Water Column Anoxia, edited by: Neretin, L. N., Dordrecht, The Netherlands, 195-224, 2006a.

Naqvi, S. W. A., Naik, H., Pratihary, A., D’Souza, W., Narvekar, P. V., Jayakumar, D. A., Devol, A. H., Yoshinari, T., and Saino, T.: Coastal versus open-ocean denitrification in the Arabian Sea, Biogeosciences, 3, 621-633, 2006b, http://www.biogeosciences.net/3/621/2006/.

National Research Council (NRC): Clean Coastal Waters - Understanding and Reducing the Effects of Nutrient Pollution, National Academy Press, Washington, DC, 2000.

National Research Council (NRC): The Mississippi River and the Clean Water Act: progress, challenges, and opportunities, National Academy Press, Washington, DC, 2008.

Nehring, D.: Eutrophication of the Baltic Sea, Sci. Total Environ. Suppl., 1992, 673-682, 1992.

Neretin, L. N.: Past and Present Water Column Anoxia. IV. Earth and Environmental Sciences, Vol. 64, NATO Science Series, Springer, 541 pp., 2006.

Newcombe, C. L. and Horne, W. A.: Oxygen-poor waters of the Chesapeake Bay, Science, 88, 80-81, 1938.

Nissling, A. and Vallin, L.: The ability of Baltic cod eggs to maintain neutral buoyancy and the opportunity for survival in fluctuating conditions in the Baltic Sea, J. Fish Biol., 48, 217-227, 1996.

Nixon, S. W.: Coastal marine eutrophication A definition, social causes, and future concerns, Ophelia, 41, 199-219, 1995.

Nixon, S. W.: Replacing the Nile Are anthropogenic nutrients providing the fertility once brought to the Mediterranean by a great river?, Ambio, 32, 30-39, 2003.

Nixon, S. W.: The artificial Nile, Am. Sci., 94, 158-165, 2004.

Nixon, S. W.: Eutophication and the macroscope, Hydrobiologia, 629, 5-19, 2009.

Nixon, S. W. and Buckley, B. A.: "A strikingly rich zone” Nutrient enrichment and secondary production in coastal marine ecosystems, Estuaries, 25, 782-796, 2002.

Nizzoli, D., Bartoli, M., Cooper, M., Welsh, D. T., Underwood, G. J. C., and Viaroli, P.: Implications for oxygen, nutrient fluxes and denitrification rates during the early stage of sediment colonisation by the polychaete Nereis spp. in four estuaries, Estuar. Coast. Shelf Sci., 75, 125-134, 2007.

Oczkowskia, A. J., Nixon, S. W., Grangera, S. L., El-Sayed, A.F. M., and McKinney, R. A.: Anthropogenic enhancement of Egypt's Mediterranean fishery, P. Natl. Acad. Sci. USA., 106, 1364-1367, 2009.

Officer, C. B. and Ryther, J. H.: The possible importance of silicon in marine eutrophication, Mar. Ecol. Prog. Ser., 3, 83-91, 1980.

Oguz, T.: Long-term impacts of anthropogenic forcing on the Black
Sea ecosystem, Oceanography, 18, 104-113, 2005.

Osterman, L. E., Poore, R. Z., Swarzenski, P. W., and Turner, R. E.: Reconstructing a $180 \mathrm{yr}$ record of natural and anthropogenic induced low-oxygen conditions from Louisiana continental shelf sediments, Geology, 33, 329-332, 2005.

Osterman, L. E., Poore, R. Z., Swarzenski, P. W., Senn, D. R., and DiMarco, S. F.: The 20th-century development and expansion of Louisiana shelf hypoxia, Gulf of Mexico, Geo-Mar. Lett., 29, 405-414, 2009.

Ostrom, N. E., Carrick, H. J., and Twiss, M. R.: Evaluation of primary production in Lake Erie by multiple proxies, Oecologia, 144, 115-124, Erratum 145, p. 669, 2005.

O’Toole, M. J., Shannon, V., de Barros Neto, V., and Malan, D.: Integrated management of the Benguela Current region A framework for future development, in: Science and Integrated Coastal Management, edited by: von Bodungen, B. and Turner, R. K., Dahlem University Press, 229-251, 2001.

Paerl, H. W., Bales, J. D., Ausley, L. W., Buzzelli, C. P., Crowder, L. B., Eby, L. A., Go, M., Peierls, B. L., Richardson, T. L., and Ramus, J. S.: Hurricane's hydrological, ecological effects linger in major US estuary, Eos, Trans. Am. Geophys. Union, 81, p. 457 and p. 462, 2000.

Panchang, R., Nigam, R., Linshy, V., Rana, S. S., and Ingole, B. S.: Effect of oxygen manipulations on benthic foraminifera A preliminary experiment, Indian J. Mar. Sci., 35, 235-239, 2006.

Parker-Stetter. S. L. and Horne J. K.: Nekton distribution and midwater hypoxia A seasonal, diel prey refuge?, Estuar. Coast. Shelf Sci., 81, 13-18, 2008.

Paulmier, A. and Ruiz-Pino, D.: Oxygen minimum zones (OMZs) in the modern ocean, Prog. Oceanogr., 80, 113-128, 2009.

Pauly, D. and Christensen, V.: Primary production required to sustain global fisheries, Nature, 374, 255-257, 1995.

Pearce, C. R., Cohen, A. S., Coe, A. L., and Burton, K. W.: Molybdenum isotope evidence for global ocean anoxia coupled with perturbations to the carbon cycle during the Early Jurassic, Geology, 36, 231-234, 2008.

Pearson, T. H., Josefson, A. B., and Rosenberg, R.: Petersen's benthic stations revisited I Is the Kattcgatt becoming eutrophic?, J. Exp. Mar. Biol. Ecol., 92, 157-206, 1985.

Petersen, C. G. J.: Valuation of the sea I, Rep. Danish Biol. Stat. No. 30, January-76, 1911.

Pizarro, O., Shaffer, G., Dewitte, B., and Ramos, M.: Dynamics of seasonal and interannual variability of the Peru-Chile undercurrent, Geophys. Res. Lett., 29, 22-1-22-4, 2002.

Pörtner, H. O. and Knust, R.: Climate change affects marine fishes through the oxygen limitation of thermal tolerance, Science, 315 , 95-97, 2007.

Prince, E. D. and Goodyear, C. P.: Hypoxia-based habitat compression of tropical pelagic fishes, Fish. Oceanogr., 15, 451-464, 2006.

Qu, J. G., Xu, Z. L., Long, Q., Wang, L., Shen, X. M., Zhang, J., and Cai, Y. L.: East China Sea, UNEP/GIWA Regional Assessment 36. University of Kalmar, Sweden, 96 pp., 2005.

Quiñones-Rivera, Z. J., Wissel, B., Justić, D., and Fry, B.: Partitioning oxygen sources and sinks in a stratified, eutrophic coastal ecosystem using stable oxygen isotopes, Mar. Ecol. Prog. Ser., 342, 60-83, 2007.

Quiñones-Rivera, Z. J., Wissel, B., Rabalais, N. N., and Justić, D.: Effects of biological and physical factors on seasonal oxygen 
dynamics in a stratified, eutrophic coastal ecosystem, Limnol. Oceanogr., 55, 289-304, 2010.

Rabalais, N. N.: Eutrophication, in: The Global Coastal Ocean Multiscale Interdisciplinary Processes, edited by: Robinson, A. R., McCarthy, J., and Rothschild, B. J., The Sea, Vol. 13, Harvard University Press, 819-865, 2004.

Rabalais, N. N. and Gilbert, D.: Distribution and consequences of hypoxia, in: Watersheds, Bays, and Bounded Seas The Science and Management of Semi-Enclosed Marine Systems, edited by: Urban, E. R., Sundby, B., Malanotte-Rizzoli, P., and Milello, J., Island Press, Washington DC, 209-225, 2008.

Rabalais, N. N. and Turner, R. E. (eds.): Coastal Hypoxia Consequences for Living Resources and Ecosystems, Coastal and Estuarine Studies 58, American Geophysical Union, Washington DC, 454 pp., 2001.

Rabalais, N. N. and Turner, R. E.: Oxygen depletion in the Gulf of Mexico adjacent to the Mississippi River, in: Past and Present Marine Water Column Anoxia, edited by: Neretin, L. N., NATO Science Series IV-Earth and Environmental Sciences, Kluwer, 225-245, 2006.

Rabalais, N. N., Harper Jr., D. E., and Turner, R. E.: Responses of nekton and demersal and benthic fauna to decreasing oxygen concentrations, in: Coastal Hypoxia Consequences for Living Resources and Ecosystems, edited by: Rabalais, N. N. and Turner, R. E., Coastal and Estuarine Studies 58, American Geophysical Union, Washington, DC, 115-128, 2001a.

Rabalais, N. N., Smith, L. E., Harper Jr., D. E., and Justić, D.: Effects of seasonal hypoxia on continental shelf benthos, in: Coastal Hypoxia Consequences for Living Resources and Ecosystems, edited by: Rabalais, N. N. and Turner, R. E., Coastal and Estuarine Studies 58, American Geophysical Union, Washington, DC, 211-240, 2001b.

Rabalais, N. N., Turner, R. E., Díaz, R. J., and Justić, D.: Global change and eutrophication of coastal waters, ICES J. Mar. Sci., 66, 1528-1537, 2009.

Rabalais, N. N., Turner, R. E., Justić, D., Dortch, Q., Wiseman Jr., W. J., and Sen Gupta, B. K.: Nutrient changes in the Mississippi River and system responses on the adjacent continental shelf, Estuaries, 19, 386-407, 1996.

Rabalais, N. N., Turner, R. E., Sen Gupta, B. K., Boesch, D. F., Chapman, P., and Murrell, M. C.: Characterization and longterm trends of hypoxia in the northern Gulf of Mexico Does the science support the Action Plan?, Estuar. Coasts, 30, 753-772, 2007a.

Rabalais, N. N., Turner, R. E., Sen Gupta, B. K., Platon, E., and Parsons, M. L.: Sediments tell the history of eutrophication and hypoxia in the northern Gulf of Mexico, Ecol. Applic. Spec. Issue Nutrient Enrichment of Estuarine and Coastal Marine Environments, 17 Supplement, S129-S143, 2007b.

Rabalais, N. N., Turner, R. E., Wiseman Jr., W. J.,, and Boesch, D. F.: A brief summary of hypoxia on the northern Gulf of Mexico continental shelf 1985-1988, in: Modern and Ancient Continental Shelf Anoxia, edited by: Tyson, R. V. and Pearson, T. H., Geological Society Special Publication No. 58, The Geological Society, London, 35-47, 1991.

Rabalais, N. N., Turner, R. E., Wiseman Jr., W. J., and Dortch, Q.: Consequences of the 1993 Mississippi River flood in the Gulf of Mexico, Regulated Rivers Res. Manag., 14, 161-177, 1998.

Rao, C. K., Naqvi, S. W. A., Kumar, M. D., Varaprasad, S. J. D.,
Jayakumar, D. A., George, M. D., and Singbal, S. Y. S.: Hydrochemistry of the Bay of Bengal Possible reasons for a different water column cycling of carbon and nitrogen from the Arabian Sea, Mar. Chem., 47, 279-290, 1994.

Renaud, M.: Hypoxia in Louisiana coastal waters during 1983 Implications for fisheries, Fish. Bull., 84, 19-26, 1986.

Richards, F. A.: Oxygen in the ocean, in: Treatise on Marine Ecology and Paleoecology, edited by: Hedgpeth, J. W., Vol. 1, Waverly Press, Baltimore, Maryland, 185-238, 1957.

Richards, F. A.: Anoxic basins and fjords, edited by: Riley, J. P. and Skirrow, G., Chem. Oceanogr., Vol. 1, Academic Press, New York, 611-645, 1965.

Riebesell, U., Schulz, K., Bellerby, R., Botros, M., Fritsche, P., Meyerhofer, M., Neill, C., Nondal, G., Oschlies, A., Wohlers, J., and Zollner, E.: Enhanced biological carbon consumption in a high $\mathrm{CO}_{2}$ ocean, Nature, 450, 545-548, 2007.

Riedel, B., Zuschin, M., and Stachowitsch, M.: Dead zones: a future worst-case scenario for northern Adriatic biodiversity, in: Climate warming and related changes in Mediterranean marine biota, edited by: Briand, F., No. 35, CIESM Workshop Monographs, Monaco, 73-78, 2008.

Ritter, C. and Montagna, P. A.: Seasonal hypoxia and models of benthic response in a Texas bay, Estuaries, 22, 7-20, 1999.

Robbins, B. D.: Quantifying temporal change in seagrass areal coverage The use of GIS and low resolution aerial photography, Aquat. Bot., 58, 259-267, 1997.

Rosenberg, R.: Effects of oxygen deficiency on benthic macrofauna in fjords, edited by: Freeland, H. J., Farmer, D. M., and Levings, C. D., Fjord Oceanography, Plenum Publishing Corp., New York, 499-514, 1980.

Rosenberg, R. and Diaz, R. J.: Sulfur bacteria (Beggiatoa spp.) mats indicate hypoxic conditions in the inner Stockholm Archipelago, Ambio, 22, 32-36, 1993.

Rosenberg, R. and Loo, L. O.: Marine eutrophication induced oxygen deficiency effects on soft bottom fauna, western Sweden, Ophelia, 29, 213-225, 1988.

Rumohr, H., Bonsdorff, E., and Pearson, T. H.: Zoobenthic succession in Baltic sedimentary habitats, Arch. Fish. Mar. Res., 44, 170-214, 1996.

Ryther, J. H.: Photosynthesis and fish production in the sea, Science, 166, 72-76, 1996.

Sakko, A. L.: The influence of the Benguela upwelling system on Namibia's marine biodiversity, Biodiv. Conserv., 7, 419-433, 1998.

Savage, C., Elmgren, R., and Larsson, U.: Effects of sewagederived nutrients on an estuarine macrobenthic community, Mar. Ecol. Prog. Ser., 243, 67-82, 2002.

Savrda, C. E., Bottjer, D. J., and Gorsline, D. S.: Development of a comprehensive oxygen-deficient marine biofacies model Evidence from Santa Monica, San Pedro, and Santa Barbara Basins, California Continental Borderland, Amer. Assoc. Petrol. Geol Bull., 68, 1179-1192, 1984.

Scavia, D., Rabalais, N. N., Turner, R. E., Justić, D., and Wiseman Jr., W. J.: Predicting the response of Gulf of Mexico hypoxia to variations in Mississippi River nitrogen load, Limnol. Oceanogr., 48, 951-956, 2003.

Schramm, W.: Factors influencing seaweed responses to eutrophication Some results from EU-project EUMAC, J. Appl. Phycol., 11, 69-78, 1999. 
Scully, M. E., Friedrichs, C., and Brubaker, J.: Control of estuarine stratification and mixing by wind-induced straining of the estuarine density field, Estuaries, 28, 321-326, 2005.

Scully, M. E.: The importance of decadal-scale climate variability to wind-driven modulation of hypoxia in Chesapeake Bay, Nature Precedings, online available at: http://hdl.handle.net/10101/ npre.2009.3308.1, 2009.

Secor, D. H. and Gunderson, T. E.: Effects of hypoxia and temperature on survival, growth, and respiration of juvenile Atlantic sturgeon, Acipenser oxyrinchus, Fish. Bull., 96, 603-613, 1998.

Secor, D. H. and Niklitschek, E. J.: Hypoxia and Sturgeons, Report to the Chesapeake Bay Program Dissolved Oxygen Criteria Team, Chesapeake Biological Laboratory, University of Maryland Center for Environmental Science, Solomons, Maryland, 26 pp., 2001.

Seitzinger, S. P., Kroeze, C., Bouwman, A. F., Caraco, N., Dentene, F., and Styles, R. V.: Global patterns of dissolved inorganic and particulate nitrogen inputs to coastal systems Recent conditions and future projections, Estuaries, 25, 640-655, 2002.

Sen Gupta, B. K., Turner, R. E., and Rabalais, N. N.: Seasonal oxygen depletion in continental-shelf waters of Louisiana Historical record of benthic foraminifers, Geology, 24, 227-230, 1996.

Shaffer, G., Olsen, S. M., and Pedersen, J. O. P.: Long-term oxygen depletion in response to carbon dioxide emissions from fossil fuels, Nature Geoscience, 2, 105-109, doi:10.1028/NGEO420, 2009.

Sherwood, E. T.: Tampa Bay water quality assessment, Tampa Bay Estuary Program Tech. Rpt. \#01-09, Tampa Bay Estuary Program, St. Petersburg, Florida, 2009.

Simon, J. L.: Tampa Bay estuarine system A synopsis, Florida Sci., 37, 217-244, 1974.

Simpson, T. W., Sharpley, A., Howarth, R. W., Paerl, H. W., and Mankin, K.: The new gold rush Fueling ethanol production while protecting water quality, J. Environ. Qual., 37, 318-324, 2008.

Skei, J. M.: Permanently anoxic marine basins Exchange of substances across boundaries, Ecol. Bull., 35, 419-429, 1983.

Snelgrove, P. V. R., Flitner, M., Urban, E. R., Jr., Ekau, W., Glaser, M., Lotze, H. K., Phillipart, K., Sompongchaiyakul, P., Yuwono, E., Melillo, J., Meybek, M., Rabalais, N. and Zhang, J.: Governance and management of ecosystem services, in: Watersheds, Bays, and Bounded Seas The Science and Management of SemiEnclosed Marine Systems, edited by: Urban, E. R., Sundby, B., Malanotte-Rizzoli, P., and Milello, J., Island Press, Washington, DC, 49-76, 2008.

Stachowitsch, M.: Mass mortality in the Gulf of Trieste The course of community destruction, Mar. Ecol., 5, 243-264, 1984.

Stachowitsch, M.: Anoxia in the Northern Adriatic Sea Rapid death, slow recovery, in: Modern and Ancient Continental Shelf Anoxia, edited by: Tyson, R. V. and Pearson, T. H., Geol. Soc. Spec. Publ. No. 58, The Geological Society, London, 119-129, 1991.

Stoeck, T., Taylor, G. T., and Epstein, S. S.: Novel eukaryotes from the permanently anoxic Cariaco Basin (Caribbean Sea), Appl. Environ. Microbiol., 69, 5656-5663, 2003.

Stramma, L., Johnson, G. C., Sprintall, J., and Mohrholz, V.: Expanding oxygen-minimum zones in the tropical oceans, Science, 320, 655-658, 2008.

Swanson, R. L. and Sindermann, C. J. (eds.): Oxygen Depletion and Associated Benthic Mortalities in New York Bight, 1976,
NOAA Professional Paper 11, US Department of Commerce National Oceanic and Atmospheric Administration, US Government Printing Office, Washington, DC, 345 pp., 1979.

Tampa Bay Estuary Program (TBEP): Charting the course, the comprehensive conservation and management plan for Tampa Bay, online available at: http//www.tbep.org/, 2006.

Taylor, G. T., Scranton, M. I., Iabichella, M., Ho, T.-Y., Thunell, R. C., and Varela, R.: Chemoautotrophy in the redox transition zone of the Cariaco Basin A significant source of midwater organic carbon production, Limnol. Oceanogr., 46, 148-163, 2001.

Thibodeau, B., de Vernal, A., and Mucci, A.: Recent eutrophication and consequent hypoxia in the bottom water of the Lower St. Lawrence Estuary Micropaleontological and geochemical evidence, Mar. Geol., 231, 37-50, 2006.

Thomas, H.: Remineralization ratios of carbon, nutrients, and oxygen in the North Atlantic Ocean A field data-based assessment, Global Biogeochem. Cy., 16, 24-1-24-12, 2002.

Tilman, D., Kilham, S. S., and Kilham, P.: Phytoplankton community ecology The role of limiting nutrients, Ann. Rev. Ecol. Syst., 13, 349-372, 1982.

Tilman, D., Fargione, J., Wolff, B., D’Antonio, C., Dobson, A., Howarth, R., Schindler, D., Schlesinger, W. H., Simberloff, D., and Swackhamer, D.: Forecasting agriculturally driven global environmental change, Science, 292, 281-284, 2001.

Tolmazin, R.: Changing coastal oceanography of the Black Sea I Northwestern shelf, Prog. Oceanogr., 15, 217-276, 1985.

Tomasko, D. A., Anastasiou, C., and Kovach, C.: Dissolved oxygen dynamics in Charlotte Harbor and its contributing watershed, in response to hurricanes Charley, Frances, and Jeanne Impacts and recovery, Estuar. Coasts, 29, 932-938, 2006.

Tong, L. and Zhang, J.: Chinese IMBER/GLOBEC program progress Dead zone survey, IMBER Update, 6, 6-8, 2007.

Trenberth, K.: Uncertainty in hurricanes and global warming, Science, 308, 1753-1754, 2005.

Tunnicliffe, V.: High species diversity and abundance of the epibenthic community in an oxygen-deficient basin, Nature, 294, 354356, 1981.

Turner, R. E.: The effects of eutrophication on pelagic and demersal marine food webs, in: Coastal Hypoxia Consequences for Living Resources and Ecosystems, edited by: Rabalais, N. N. and Turner, R. E., Coastal and Estuarine Studies 58, American Geophysical Union, Washington, DC, 371-398, 2001.

Turner, R. E. and Rabalais, N. N.: Coastal eutrophication near the Mississippi river delta, Nature, 368, 619-621, 1994.

Turner, R. E., Qureshi, N., Rabalais, N. N., Dortch, Q., Justić, D., Shaw, R. F., and Cope, J.: Fluctuating silicate:nitrate ratios and coastal plankton food webs, P. Natl. Acad. Sci. USA, 95, 1304813051, 1998.

Turner, R. E., Rabalais, N. N., and Justić, D.: Gulf of Mexico hypoxia Alternate states and a legacy, Environ. Sci. Technol., 42, 2323-2327, 2008.

Turner, R. E., Rabalais, N. N., and Justić, D.: Predicting summer hypoxia in the northern Gulf of Mexico Riverine N, P, and Si loading, Mar. Pollut. Bull., 52, 139-148, 2006.

Turner, R. E., Rabalais, N. N., Justić, D., and Dortch, Q.: Global patterns of dissolved silicate and nitrogen in large rivers, Biogeochemistry, 64, 297-317, 2003.

Tyler, R. M., Brady, D. C., and Targett, T. E.: Temporal and spatial dynamics of diel-cycling hypoxia in estuarine tributaries, Estuar. 
Coasts, 32, 123-145, 2009.

Tyson, R. V. and Pearson, T. H. (eds.): Modern and Ancient Continental Shelf Anoxia, Geol. Soc. Spec. Publ. No. 58, The Geological Society, London, 490 pp., 1991a.

Tyson, R. V. and Pearson, T. H.: Modern and ancient continental shelf anoxia An overview, in: Modern and Ancient Continental Shelf Anoxia, edited by: Tyson, R. V. and Pearson, T. H., Geol. Soc. Spec. Publ. No. 58, The Geological Society, London, 1-24, 1991b.

US Environmental Protection Agency (USEPA): Hypoxia in the Northern Gulf of Mexico An Update. Science Advisory Board, Hypoxia Assessment Panel, EPA-SAB-08-004, 333 pp., 2008.

Ueda, N., Tsutsumi, H., Yamada, M., Hanamoto, K., and Montani, S.: Impacts of oxygen-deficient water on the macrobenthic fauna of Dokai Bay and on adjacent intertidal flats, in Kitakyushu, Japan, Mar. Pollut. Bull., 40, 906-913, 2000.

Vahtera, E., Conley, D. J., Gustafsson, B. G., Kuosa, H., Pitkänen, H., Savchuk, O. P., Tamminen, T., Viitasalo, M., Voss, M., Wasmund, N., and Wulff, F.: Internal ecosystem feedbacks enhance nitrogen fixing cyanobacteria blooms and complicate management in the Baltic Sea, Ambio, 36, 186-194, 2007.

Vaquer-Sunyer, R. and Duarte, C. M.: Thresholds of hypoxia for marine biodiversity, P. Natl. Acad. Sci. USA, 105, 15452-15457, 2008.

Vecchi, G. A. and Soden, B. J.: Global warming and the weakening of the tropical circulation, J. Climate, 20, 4316-4340, 2007.

Verity, P. G., Alber, M., and Bricker, S. B.: Development of hypoxia in well-mixed subtropical estuaries in the southeastern USA, Estuar. Coasts, 29, 665-673, 2006.

Walsh, J. J.: Importance of continental margins in the marine biogeochemical cycling of carbon and nitrogen, Nature, 350, 53-55, 1991.

Wang, B.: Cultural eutrophication in the Changjiang (Yangtze River) plume History and perspective, Estuar. Coast. Shelf Sci., 69, 471-477, 2006.

Wang, H., Yang, Z., Saito, Y., Liu, J. P., and Sun, X.: Interannual and seasonal variation of the Huanghe (Yellow River) water discharge over the past 50 years Connections to impacts from ENSO events and dams, Global Planet. Change, 50, 212-225, 2006.

Wang, X., Depew, D., Schiff, S., and Smith, R. E. H.: Photosynthesis, respiration, and stable isotopes of oxygen in a large oligotrophic lake (Lake Erie, U.S.A.-Canada), Can. J. Fish. Aquat. Sci., 65, 2320-2331, 2008.

Wang, L. and Justić, D.: A modeling study of the physical processes affecting the development of seasonal hypoxia over the inner Louisiana-Texas shelf Circulation and stratification, Cont. Shelf Res., 29, 1464-1476, 2006.

Ward, C. H., Bender, M. E., and Reish, D. J. (eds.): The offshore ecology investigation Effects of oil drilling and production in a coastal environment, Rice University Studies, 65, 1-589, 1979.
Weeks, S., Currie, B., and Bakun, A.: Massive emission of toxic gas in the Atlantic, Nature, 415, 493-494, 2002.

Wei, H., He, Y., Li, Q., Liu, Z., and Wang, H.: Summer hypoxia adjacent to the Changjiang Estuary, J. Mar. Syst., 67, 292-303, 2007.

Weissberger, E. J., Coiro, L. L., and Davey, E. W.: Effects of hypoxia on animal burrow construction and consequent effects on sediment redox profiles, J. Exp. Mar. Biol. Ecol., 371, 60-67, 2009.

Whitledge, T. E.: Nationwide review of oxygen depletion and eutrophication in estuarine and coastal waters Executive summary, Report to National Ocean Service, National Oceanic and Atmospheric Administration. Brookhaven National Laboratory, Upton, New York, 28 pp., 1985.

Whitney, F. A., Freeland, H. J., and Robert, M.: Persistently declining oxygen levels in the interior waters of the eastern subarctic Pacific, Prog. Oceanogr., 75, 179-199, 2007.

Wilson, P. A. and Norris, R. D.: Warm tropical ocean surface and global anoxia during the mid-Cretaceous period, Nature, 412, 425-429, 2001.

Wolock, D. M. and McCabe, G. J.: Estimates of runoff using waterbalance and atmospheric general circulation models, J. Am. Water Resour. Assoc., 35, 1341-1350, 1999.

Wu, R. S. S.: Hypoxia: from molecular responses to ecosystem responses, Mar. Pollut. Bull., 45, 35-45, 2002.

Wu, R. S. S., Zhou, B. S., Randall, D. J., Woo, N. Y. S., and Lam, P. K. S.: Aquatic hypoxia is an endocrine disruptor and impairs fish reproduction, Environ. Sci. Technol., 37, 1137-1141, 2003.

Wyrtki, K.: Oceanography of the eastern equatorial Pacific Ocean, Oceanogr. Mar. Biol. Ann. Rev., 4, 33-68, 1966.

Yang, S., Li, C., and Cai, J.: Geochemical compositions of core sediments in eastern China Implication for Late Cenozoic palaeoenvironmental changes, Palaeogeo. Palaeoclimat. Palaeoecol., 229, 287-302, 2006.

Zaitsev, Y. P.: Recent changes in the trophic structure of the Black Sea, Fish. Oceanogr., 1, 180-189, 1992.

Zhang, J., Huang, W. W., Liu, M. G., and Cui, J. Z.: Ecosocial impact and chemical regimes of large Chinese rivers A short discussion, Water Res., 28, 609-617, 1994.

Zhang, J., Zhang, Z. F., Liu, S. M., Wu, Y., Xiong, H., and Chen, H. T.: Human impacts on the large world rivers Would the Changjiang (Yangtze River) be an illustration?, Global Biogeochem. Cy., 13, 1099-1105, 1999.

Zhu, Z. Y.: Hypoxia in the Changjiang Estuary and its adjacent area - Started with phytoplankton pigments, Ph.D. Dissertation, East China Normal University, Shanghai, 209 pp., 2007 (in Chinese).

Zillén, L., Conley, D. J., Andrén, T., Andrén, E., and Björck, S.: Past occurrences of hypoxia in the Baltic Sea and the role of climate variability, environmental change and human impact, Earth Sci. Rev., 91, 77-92, 2008. 